DOE!EA-0843

June 1994

\title{
ENVIRONMENTAL ASSESSMENT IDAHO NATIONAL ENGINEERING LABORATORY LOW-LEVEL AND MIXED WASTE PROCESSING
}

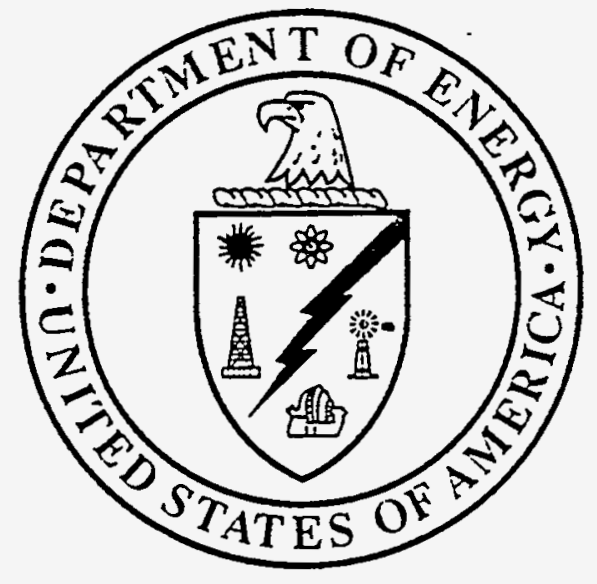

Prepared for the

U.S. DEPARTMENT OF ENERGY

Office of Environmental Restoration and Waste Management 


\section{DISCLAIMER}

This report was prepared as an account of work sponsored by an agency of the United States Government. Neither the United States Government nor any agency thereof, nor any of their employees, make any warranty, express or implied, or assumes any legal liability or responsibility for the accuracy, completeness, or usefulness of any information, apparatus, product, or process disclosed, or represents that its use would not infringe privately owned rights. Reference herein to any specific commercial product, process, or service by trade name, trademark, manufacturer, or otherwise does not necessarily constitute or imply its endorsement, recommendation, or favoring by the United States Government or any agency thereof. The views and opinions of authors expressed herein do not necessarily state or reflect those of the United States Government or any agency thereof. 


\section{DISCLAIMER}

Portions of this document may be illegible in electronic image products. Images are produced from the best available original document. 


\section{PREFACE}

In response to public comments, DOE is now proposing only a portion of the proposed actions analyzed in this Environmental Assessment (EA). The following provides information about the modified proposed action.

DOE initially prepared a draft EA to assess the environmental impacts of a previous proposal. The previous proposal was to (1) provide treatment, in compliance with the Resource Conservation and Recovery Act, by production-scale incineration of mixed low-level waste (MLLW) at the Idaho National Engineering Laboratory (INEL) Waste Experimental Reduction Facility (WERF); (2) reduce the volume of INEL-generated low-level waste (LLW) through sizing, compaction, stabilization, and incineration at WERF; and (3) use commercial offsite facilities for supplemental LLW volume reduction (incineration).

DOE is now proposing not to incinerate MLLW or LLW at WERF at this time. Onsite sizing, compaction, and stabilization of INEL-generated LLW for volume reduction as discussed in the EA are still being proposed. Incineration of $L L W$ at an offsite commercial (non-DOE) facility is also still proposed. Under the modified proposal, incineration of MLLW and LLW at WERF will not occur unless and until such a decision is made in the Record of Decision, based on the Department of Energy Programmatic Spent Nuclear Fuel Management and Idaho National Engineering Laboratory Environmental Restoration and Waste Management Programs Environmental Impact Statement (SNF and INEL EIS).

The original proposed action, referred to as the "proposal" in the body of this EA, is an alternative to the current, modified proposal. In addition, the EA evaluates five other alternative actions: no action, alternative MLLW treatment and WERF operations for LLW only, LLW disposal without volume reduction and storage only for MLLW, the construction and operation of a new MLLW incinerator and continued WERF operations for LLW, and treatment of MLLW at another DOE MLLW incinerator and continued WERF LLW operations.

The EA includes analysis of the environmental impacts of the current modified proposal. The EA analyzes the impacts of (1) LLW sizing, compaction, and stabilization at INEL; (2) offsite treatment (by incineration at the Scientific Ecology Group, Inc. facility in Oak Ridge, Tennessee or a alternative, non-DOE, commercial facility) and return of the ash to INEL prior to disposal at INEL; and (3) the continued storage of untreated MLLW at INEL. The portions of the current proposed action at INEL would occur in an existing previously developed area and would not affect wetlands, floodplains, rare or endangered species or their habitat, or archaeological resources. Significant construction would not be required, and there are no significant socioeconomic impacts since the workforce is already in place.

Because incineration activities at WERF will not occur unless and until such a decision is made in the Record of Decision for the SNF and INEL EIS, the incinerator-based atmospheric emissions from the WERF of radionuclides, criteria pollutants, or organic or metallic carcinogens would not occur. Sizing, compaction, and stabilization activities would involve only INEL generated LLW, and there would be no associated organic or metallic carcinogen atmospheric emissions. The sizing and compaction room ventilation air would be filtered by two baghouses in series and a high-efficiency particulate air filter, which have a combined particulate removal efficiency of 99.99 percent. The 
National Emission Standards for Hazardous Air Pollutants standard for radiation emissions under 40 Code of Federal Regulations (CFR) Part 61 is $10 \mathrm{mrem}$. The INEL has established and operational site limit of $0.1 \mathrm{mrem}$. The emissions projected for sizing, compacting, and stabilizing operations would result in radiation effective dose equivalents which are well below the $0.1 \mathrm{mrem}$ operational limit. Sizing, compacting, and stabilizing activities at WERF would result in less than 0.0001 latent cancer fatalities per year from radiological releases to the affected population of 160,120 persons.

Section 4.2 of the EA discusses the impacts expected from the shipment of INEL LLW (to and from INEL) for offsite volume reduction. These associated actions may result in radiological exposures to truck drivers and the public from incident-free operations and accidents. The maximum cumulative radiological health risk to transportation workers from incident-free shipping over a 20 year campaign is 0.09 fatalities; for the public under this same campaign of shipments, the incidentfree risk is 0.8 fatalities. An additional 0.8 excess fatalities would result to workers from accidents.

Proposed offsite incineration of INEL LLW would be conducted at a private (non-DOE) facility subject to air emission standards. The source terms (i.e., the amount and types of materials to be incinerated) are provided in the EA for the WERF incinerator, as are the associated impacts of normal operations and accidents. The incremental impacts of proposed offsite incineration of INEL LLW are expected to be similar. The radiological exposures (estimated to be $1.1 \mathrm{mrem}$ ) associated with incineration of LLW would be approximately $1 / 500$ and 1/5000 of the DOE limits for workers $(500 \mathrm{mrem} / \mathrm{yr}$ for non-radiation workers and $5000 \mathrm{mrem} / \mathrm{yr}$ for radiation workers, respectively) and $1 / 100$ (estimated to be $.096 \mathrm{mrem}$ ) of the permissible dose to a maximally exposed member of the public (10 mrem/yr) (EA Section 4.1.1.1). These exposures would result in a lifetime risk of contracting fatal cancer for an individual exposed for 70 years of less than 1 in 10,000. Nonradiological chemical impacts from organic or metallic carcinogens would not occur since MLLW would not be incinerated.

Because incineration activities at WERF would not occur, the accidents associated with incinerator operations at INEL would not occur. Accidents associated with compactor operations are discussed in the EA. A compactor fire would not have significant worker or public health impacts because the high-efficiency particulate air filters are located external to the compactor building. The details of the bounding compactor accident are in Section 4.3.4 of the EA.

Under the modified proposal, DOE will not incinerate MLLW or LLW at WERF unless and until such decisions are made in the Record of Decision based on analyses in the SNF and INEL EIS. This SNF and INEL EIS will discuss overall INEL waste management activities, programs, and projects proposed for INEL. The SNF and INEL EIS is scheduled to be issued to the public in draft in June 1994; the final EIS is scheduled to be issued in April 1995, and the Record of Decision in June 1995. However, the modified proposal concerning LLW is needed for the current and anticipated inventory of LLW regardless of whether any future decision is made in the Record of Decision to incinerate LLW and MLLW at WERF. The proposal would not necessitate, or otherwise influence, any future decision to incinerate either LLW or MLLW at WERF. Also, the proposed offsite incineration of LLW would be geographically separate from, and would primarily affect different workers and different populations than, any future incineration at WERF. 
The modified proposal is not encompassed within the classes of actions that normally require an EA or an environmental impact statement under DOE's National Environmental Policy Act Implementing Procedure, $40 \mathrm{CFR}$ Subpart D, Appendices C and D. Therefore, in accordance with 40 CFR 1021.400, DOE has prepared this EA, as modified by this preface, to determine whether to prepare an EIS for the current proposal or to issue a finding of no significant impact. 


\section{IDAHO NATIONAL ENGINEERING LABORATORY \\ FINDING OF NO SIGNIFICANT IMPACT FOR LOW-LEVEL \\ AND MIXED WASTE PROCESSING}

AGENCY: U. S. Department of Energy

ACTION: Finding of No Significant Impact

SUMARY: The Department of Energy (DOE) has prepared an environmenta] assessment (EA), DOE/EA-0843, for the Idaho National Engineering Laboratory (INEL) low-Tevel and mixed waste processing. The original proposed action, as reviewed in this EA, was (1) to incinerate INEL's mixed low-level waste (MLLW) at the Waste Experimental Reduction Facility (WERF); (2) reduce the volume of INEL generated low-level waste (LLW) through sizing, compaction, and stabilization at the WERF; and (3) to ship INEL LLW to a commercial. incinerator for supplemental $L L H$ volume reduction.

In response to public comments, DOE is no longer proposing at this time the portions of the original proposed action related to the incineration of MLLW at the WERF. Rather, as explained in the Preface to the EA, DOE has decided to propose an additional alternative which consists of sizing, compacting, and stabilizing (i.e., mixing ash with cement) LLW at the WERF, shipment of INEL LLW to an offsite incinerator, and continued storage of MLLW. Future decisions on treatment of $L L W$ and MLLW by means such as incineration at WERF would be deferred until the completion of the Programmatic Spent Nuclear Fue] 
Management and INEL Environmental Restoration and Waste Management Programs Environmental Impact Statement.

Based on the anatyses in the EA, the DOE has determined that the proposed action, as defined in the Preface to the EA, is not a major Federal action significantly affecting the quality of the human environment, within the meaning of the National Environmental Policy Act. Therefore, the preparation of an environmental impact statement is not required, and DOE is issuing this finding of no significant impact.

\section{COPIES OF THE EA ARE AVAILABLE FROM:}

Mr. R. A. King

Idaho Operations Office

$U$. S. Department of Energy

785 DOE Place

Idaho Fa7ls, ID 83402-1118

(208) $526-1633$

FOR FURTHER INFORMATION ON THE NATIONAL ENVIRONMENTAL POLICY ACT PROCESS CONTACT:

Ms. Carol Borgstrom, Director

Office of NEPA Oversight (EH-25)

U.S. Department of Energy

1000 Independence Avenue, SW

Washington, DC 20585

(202) $586-4600$ or leave a message at (800) $472-2756$

PROPOSED ACTION: The proposed project would (1) reduce the volume of the INEL-generated LLW through sizing, compaction, and stabilization at the WERF, (2) ship the INEL LLW to a commercial off-site incinerator for supplemental LLW volume reduction, and (3) continue storage of MLLW at the INEL storage facitities. 
WERF has been an essential component of the INEL's waste management program since 1982 because its processes reduce the volume of waste requiring disposal as well as the toxicity and mobility of the waste being treated. However, operations of WERF were suspended in February 1991 to upgrade safety documentation, operating procedures, and management systems.

The proposed WERF operations would reduce the need to store accumulated waste, which in turn would reduce the radiation exposure to INEL workers and reduce the risk of additional exposure from storage container deterioration. The proposed action would also reduce the volume of waste being disposed of at the Radioactive Waste Management Complex, thereby conserving its disposal capacity. Under this alternative, the remaining storage capacity at the Radioactive Waste Management Complex would be consumed in about 21 years.

The proposed action includes transporting LLW to a commercial treatment facility for incineration to reduce the waste volume. The current proposal is to truck the LLW to a commercial incinerator, such as the Scientific Ecology Group, Inc. facility in Oak Ridge, Tennessee or an alternative facility. The resultant ash would be treated as appropriate and returned to INEL for management and disposal at the Radioactive Waste Management Complex.

Wastes proposed for volume reduction as part of the proposed action include the accumulated LLW and the LLW expected to be generated by ongoing and planned INEL operations. The waste proposed for volume reduction would have to meet the WERF waste acceptance criteria related to package size; type, and weight. • 
LLW currently stored at the various INEL facilities is approximately 10,000 cubic meters $\left(\mathrm{m}^{3}\right)$ and future INEL activities are expected to generate approximately $4,000 \mathrm{~m}^{3}$ each year. MLLW currently stored at the various INEL facilities is approximately $100 \mathrm{~m}^{3}$. Future INEL activities are expected to generate approximately $50 \mathrm{~m}^{3}$ of MLLW each year, which would continue to be stored at the INEL.

ENVIRONMENTAL IMPACTS: The proposed action would occur in an existing, previously-developed INEL area and would not affect wetlands, floodplains, rare or endangered species or their habitat, archeological, or cultural resources. Significant construction activities would not be required, and there are no anticipated socioeconomic effects because the work force for the WERF is already in place.

Normal Operations. Airborne emissions of radionuclides would occur as a result of the compacting, sizing, and stabilizing of LLW. Offgas and ventilation air would be processed through a baghouse, prefilter, and highefficiency particulate air filter before being discharged to the atmosphere to reduce the emissions.

The risk of an individual developing fatal cancer during his or her lifetime as a result of WERF emissions would be extremely low. The population of 160,000 within 80 kilometers of WERF could be exposed to a radiation dose of 0.2 person-rem per year from the proposed action; the estimated number of fatal cancers induced among this population from the radiation would be less than 0.0001 per year. Based on conservative assumptions, HERF operations 
would result in a maximally exposed individual at the INEL boundary receiving an estimated dose of less than 0.1 mrem per year. This projected exposure level is less than one percent of the Environmental Protection Agency limit of 10 mrem per year that applies to the total air emissions from INEL. The maximum estimated exposure to a worker 100 meters from WERF is projected to be 1.0 mrem per year. It is most likely there would be no fatal cancers among workers and the public attributable to the proposed action at WERF.

Cumulative radiological doses to the population from all existing and proposed INEL activities woutd be less than 0.85 person-rem per year, which is . estimated to result in less than 0.0001 additional latent cancer fatalities per year to the affected population.

Iransportation. Preparation and transport of LLW from the INEL- to a commercial processing facility would be performed in accordance with DOE, Department of Transportation, Nuclear Regulatiory Commission, and State requirements. A conservative analysis of transportation activities estimated that maximum cumulative radiological and non-radiological health risk to the public from incident-free transport may result in 0.8 excess cancer deaths in the exposed population over the 20-year shipping campaign. An estimated 0.8 deaths may a! so occur from radiological releases resulting from transportation accidents. In comparison, about 3,000 cancer deaths from al1 other sources would be expected in the same population over the 20-year shipping campaign. 
Commercial Incinerator. Based on the pertinent circumstances, DOE does not expect that the INEL LLW would constitute a significant change in the overal1 level of operations of the commercial facility. Processing the INEL LLW waste would not materially change emission rates from its normal operations. The emissions from commercial facilities are controlled by regulatory limits, license restrictions, waste acceptance criteria, and process controls and are designed to adequately protect human health and the environment.

Potential Accidents. Impact analyses were conducted for a range of accidents at WERF. The maximum reasonably foreseeable accident relevant to the proposed action as modified by the Preface. would be a compactor fire. In the event of a compactor fire, which has an estimated probability of $9.0 \times 10^{-5} / \mathrm{yr}$, a worker in the compactor room is assumed to be exposed for 10 minutes, while workers $100 \mathrm{~m}$ away and the maximally exposed individual are exposed for 8 hours. The fire would release $2.8 \mathrm{Ci}$ of radioactivity, exposing workers in the compactor room and $100 \mathrm{~m}$ away to doses of about $70 \mathrm{mrem}$ each while the dose to the maximally exposed individual offsite would be $0.11 \mathrm{mrem}$. No adverse heaith effects would be expected from any of these doses.

ALTERNATIVES CONSIDERED: The EA, as modified by the Preface, evaluates the following alternatives:

(1) The original proposed action - This alternative would incinerate MLLW at the WERF; reduce the volume of the INEL-generated LLW through sizing, compacting, stabilizion, and incineration at the WERF; and ship the INEL LLW to a commercial incinerator for supplemental $\mathrm{LLW}$ volume reduction. Under this 
alternative, the remaining storage capacity at the Radioactive Waste Management Complex would be consumed in about 21 years. (Under the current proposal, any incineration of LLW and MLLW at the WERF would be deferred until the completion of the Programmatic Spent Nuclear Fuel Management and INEL Environmental Restoration and Waste Management Environmental Impact Statement.)

(2) No Action - This alternative would require the DOE to continue storing INEL MLLW in INEL storage facilities while using WERF for LLW volume reduction. This alternative could result in lower short-term worker exposure, but because of the prolonged storage requirements for MLLW could potentially result in long-term exposures. While this alternative would not assume the risk of shipping the LLH to a commercial facility, the continued treatment of the LLW at WERF would require storing, handling, and monitoring at INEL unti7 it could be processed. Under this alternative, the remaining storage capacity at the Radioactive Waste Management Complex would be consumed in five to seven years.

(3) Treat MLLW by Methods Other Than Incineration and Continue Use of WERF to Incinerate, Compact, and Size LLW - This alternative would require gaining EPA approval for a different kind of treatment (incineration is the only approved treatment for many hazardous wastes), while delaying MLLW treatment until the demonstration and approval process ended. The alternatives include stabilization and biological and chemical treatment. The former does not reduce the toxicity of the waste and thus risks contaminating the disposal 
site, while the latter increases the likelihood of exposure, because of the multiple processes required.

(4) Dispose of LLW Without Volume Reduction and Continue to Store MLLW - This would increase the risk of worker exposure, because of the greater number of containers of $L L W$ and MLLW requiring management. Under this alternative, the remaining storage capacity at the Radioactive Waste Management Complex would be consumed in five to seven years.

(5) Construct and Operate a New MLLW Incinerator and Continue to Incinerate, Compact, and Size LLW at the WERF - This would be inefficient, because two incinerators would be used where only one is necessary. In addition, there would be no environmental benefit from this arrangement, and MLLW would have to be stored until the new incinerator was built and permitted.

(6) Treat MLLW at Another DOE Incinerator and Continue to Incinerate, Compact, and Size LLW at the WERF - This is not an available option for MLLW; it would take at least three to five years before an existing or proposed DOE facility could be permitted to process the INEL waste.

DETERMINATION: Based on the information and analys is in the EA as modified by the Preface, DOE has determined that the proposed action at the INEL does not constitute a major Federal action significantly affecting the quality of the 
human environment within the meaning of the National Environmental Policy Act. Therefore an environmental impact statement for the proposed action is not required.

Issued at Washington, D.C., this. $3^{d}$ day of tues, 1994.

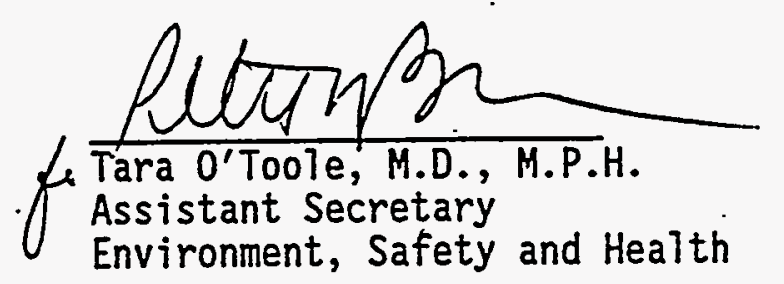


June 1994

\section{CONTENTS}

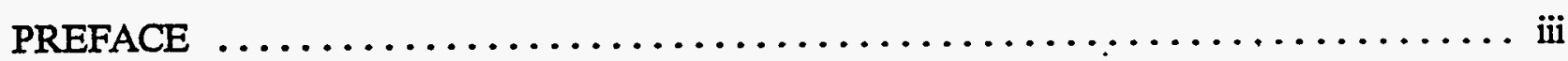

FINDING OF NO SIGNIFICANT IMPACT FOR LOW-LEVEL AND MIXED

WASTE PROCESSING $\ldots \ldots \ldots \ldots \ldots \ldots \ldots \ldots \ldots \ldots \ldots \ldots \ldots \ldots \ldots$

ACRONYMS AND ABBREVIATIONS $\ldots \ldots \ldots \ldots \ldots \ldots \ldots \ldots \ldots \ldots \ldots \ldots$

1. INTRODUCTION $\ldots \ldots \ldots \ldots \ldots \ldots \ldots \ldots \ldots \ldots \ldots \ldots \ldots \ldots \ldots \ldots \ldots$

1.1 Background $\ldots \ldots \ldots \ldots \ldots \ldots \ldots \ldots \ldots \ldots \ldots \ldots \ldots \ldots \ldots \ldots \ldots \ldots$

1.2 Purpose of Agency Action $\ldots \ldots \ldots \ldots \ldots \ldots \ldots \ldots \ldots \ldots \ldots \ldots \ldots \ldots$

1.3 Need for Agency Action $\ldots \ldots \ldots \ldots \ldots \ldots \ldots \ldots \ldots \ldots \ldots \ldots \ldots \ldots$

1.4 Scope of the EA $\ldots \ldots \ldots \ldots \ldots \ldots \ldots \ldots \ldots \ldots \ldots \ldots \ldots \ldots \ldots \ldots$

1.5 EA Justification $\ldots \ldots \ldots \ldots \ldots \ldots \ldots \ldots \ldots \ldots \ldots \ldots \ldots \ldots \ldots \ldots$

1.6 Relationship to Other NEPA Reviews $\ldots \ldots \ldots \ldots \ldots \ldots \ldots \ldots \ldots \ldots \ldots \ldots$

2. PROPOSED ACTION AND ALTERNATIVES . . . . . . . . . . . ... 11

2.1 Proposed MLLW Incineration $\ldots \ldots \ldots \ldots \ldots \ldots \ldots \ldots \ldots \ldots \ldots \ldots \ldots$

2.2 Proposed Commercial LLW Treatment $\ldots \ldots \ldots \ldots \ldots \ldots \ldots \ldots \ldots \ldots$

2.3 WERF Facilities and Incineration Process $\ldots \ldots \ldots \ldots \ldots \ldots \ldots \ldots$

2.4 Alternatives to the Proposed Action $\ldots \ldots \ldots \ldots \ldots \ldots \ldots \ldots \ldots \ldots \ldots$

$2.4 .1 \quad$ No Action Alternative $\ldots \ldots \ldots \ldots \ldots \ldots \ldots \ldots \ldots \ldots \ldots \ldots$

2.4.2 Treat MLLW by Methods Other Than Incineration and Continue Use of WERF to Incinerate, Compact, and Size LLW . . . . 16

2.4.3 Dispose of LLW Without Volume Reduction and Continue to Store MLLW .......................... 16

2.4.4 Construct and Operate a New MLLW Incinerator and Continue to Incinerate, Compact, and Size LLW at WERF . . . . . . . . 16

2.4.5 Treat MLLW at Another DOE Incinerator and Continue to Incinerate, Compact, and Size LLW at WERF . . . . . . . . . 17

3. AFFECTED ENVIRONMENT ........................ 18 
June 1994

3.1 Physical Environment.$\ldots \ldots \ldots \ldots \ldots \ldots \ldots \ldots \ldots \ldots \ldots \ldots \ldots \ldots \ldots \ldots \ldots \ldots$

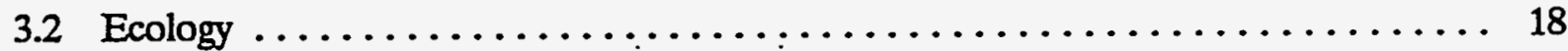

3.3 Socioeconomics and Cultural Resources . . . . . . . . . . . . . . . . 19

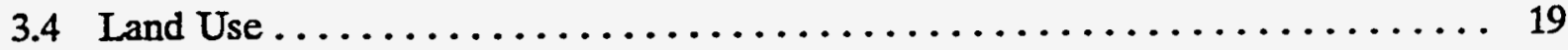

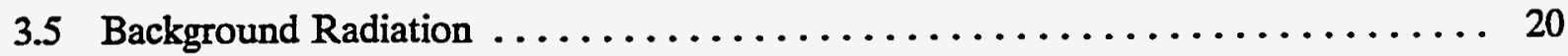

4. ENVIRONMENTAL IMPACTS OF THE PROPOSED ACTION AND

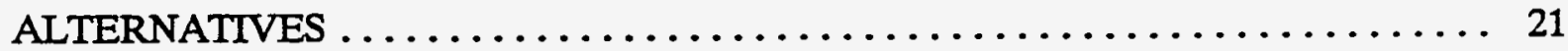

4.1 Operational Impacts of Proposed Action $\ldots \ldots \ldots \ldots \ldots \ldots \ldots \ldots \ldots \ldots \ldots \ldots \ldots$

4.1.1 Impacts from Waste Incineration $\ldots \ldots \ldots \ldots \ldots \ldots \ldots \ldots \ldots .22$

4.1.2 Impacts from Compaction and Sizing $\ldots \ldots \ldots \ldots \ldots \ldots \ldots \ldots \ldots \ldots \ldots \ldots \ldots \ldots \ldots$

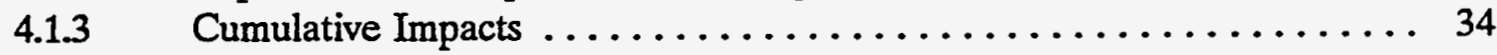

4.2 Impacts of Transportation of $L L W$ to and from INEL $\ldots \ldots \ldots \ldots \ldots \ldots \ldots$

4.3 Potential Impacts from Accidents $\ldots \ldots \ldots \ldots \ldots \ldots \ldots \ldots \ldots \ldots \ldots \ldots$

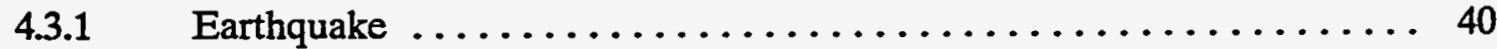

4.3 .2 Baghouse/HEPA Filter Fire $\ldots \ldots \ldots \ldots \ldots \ldots \ldots \ldots \ldots \ldots, 40$

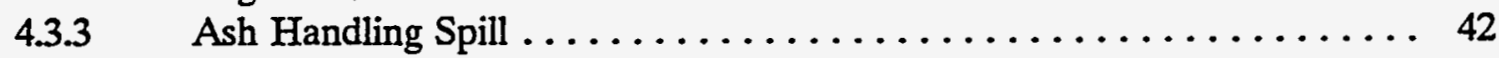

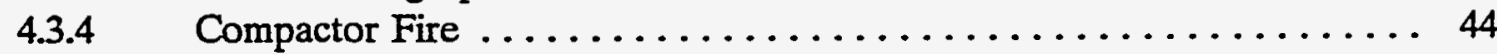

4.4 Impacts of Alternatives to the Proposed Action $\ldots \ldots \ldots \ldots \ldots \ldots \ldots \ldots 44$

4.4.1 The No Action Alternative $\ldots \ldots \ldots \ldots \ldots \ldots \ldots \ldots \ldots \ldots . \ldots 4$

4.4.2 Treat MLLW By Methods Other Than Incineration and

Continue Use of WERF to Incinerate, Compact, and Size LLW .... 47

4.4.3 Dispose of LLW Without Volume Reduction and Continue to Store MLLW ......................... 47

4.4.4 Construct and Operate a New MLLW Incinerator and Continue to Incinerate, Compact, and Size LLW at WERF ........... 48

4.4.5 Treat MLLW at Another DOE Incinerator and Continue to Incinerate, Compact, and Size LLW at WERF ........... 48

5. WERF PERMITS AND AGENCIES/PERSONS CONSULTED $\ldots \ldots \ldots \ldots \ldots .49$

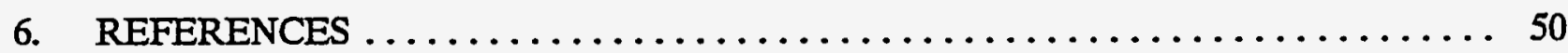

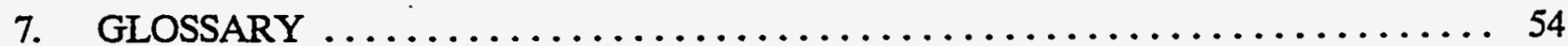


Appendix A-Responses to the State of Idaho and the Shoshone-Bannock

Tribes Comments

\section{FIGURES}

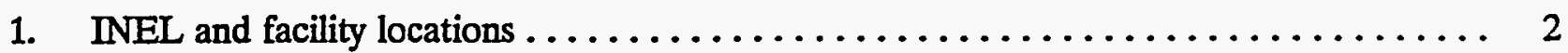

2. WERF waste stream flow diagram $\ldots \ldots \ldots \ldots \ldots \ldots \ldots \ldots \ldots \ldots \ldots \ldots \ldots \ldots$

3. Layout of WERF facilities $\ldots \ldots \ldots \ldots \ldots \ldots \ldots \ldots \ldots \ldots \ldots \ldots \ldots \ldots \ldots$

\section{TABLES}

1. Inventory of LLW and MLLW through September 1993, and INEL generation rates ... 7

2. Radionuclide release rate limits from the WERF north stack . . . . . . . . . . . 24

3. Estimated maximum dose consequences to three receptor groups from LLW and proposed MLLW incineration and LLW compaction and sizing at WERF . . . . . 25

4. Maximum release rates of criteria pollutants from routine WERF operations . . . . . 27

5. $\mathrm{AACs}^{\mathrm{a}}$ and $\mathrm{TLVs}$ (in $\mathrm{mg} / \mathrm{m}^{3}$ ) for representative nonchlorinated and chlorinated organic compounds potentially released during routine mixed waste incineration $\ldots . \ldots 28$

6. Calculated concentrations of WERF metals, based on maximum allowable feed rates, compared to TLVs and AACs . . . . . . . . . . . . . . . . . . .

7. Carcinogenic risk to the MEI from maximum releases of nonradiological carcinogens from the WERF incinerator $\ldots \ldots \ldots \ldots \ldots \ldots \ldots \ldots \ldots \ldots \ldots$

8. Estimated radionuclide release rate limits from the WERF east stack ......... 33

9. Estimated cumulative radiological doses from existing INEL activities, proposed RWMC remedial activities, and WERF operations ................ 35

10. Summary of health effects from transportation of $\operatorname{LLW} \ldots \ldots \ldots \ldots \ldots \ldots \ldots$

11. Estimated metal concentrations resulting from the earthquake accident $\ldots \ldots \ldots \ldots$... 41

12. Estimated metal concentrations resulting from the baghouse/HEPA fire accident . . . . 42

13. Estimated metals concentrations at receptor locations resulting from ash spill releases 
June 1994

14. Comparative impacts of proposed action and alternatives $\ldots \ldots \ldots \ldots \ldots \ldots \ldots \ldots$ 


\section{ACRONYMS AND ABBREVIATIONS}

$\mathrm{AAC}$

AACC

ACGIH

CFR

DOE

DRE

EA

EDE

EIS

EM

EPA

ER\&WM

FR

$\mathrm{HCl}$

HEPA

IDAPA

IDEQ

IDLH

INEL

LANL

LDR

LLW acceptable ambient concentration

acceptable ambient concentrations for carcinogens

American Conference of Government Industrial Hygienists

Code of Federal Regulations

U.S. Department of Energy

destruction removal efficiency

Environmental Assessment

effective dose equivalent

Environmental Impact Statement

Office of Environmental Restoration and Waste Management

Environmental Protection Agency

environmental restoration and waste management

Federal Register

hydrochloric acid

high-efficiency particulate air

Idaho Administrative Procedures Act

State of Idaho Department of Environmental Quality

immediately dangerous to life and health

Idaho National Engineering Laboratory

Los Alamos National Laboratory

land disposal restriction

low-level waste 
MEI maximally exposed individual

MLLW . mixed low-level waste

NCI National Cancer Institute

NEPA National Environmental Policy Act

NESHAP National Emission Standards for Hazardous Air Pollutants

NIC Notice of intended change

NIOSH National Institute of Occupational Safety and Health

$\mathrm{NO}_{\mathrm{x}} \quad$ nitrogen oxides

NRC Nuclear Regulatory Commission

NRHP National Register of Historic Places

NSB nearest site boundary.

ORR Oak Ridge Reservation

OSHA Occupational Safety and Health Act

PEIS Programmatic Environmental Impact Statement

PEL permissible exposure limit

RCRA Resource Conservation and Recovery Act

RFP Rocky Flats Plant

RWMC Radioactive Waste Management Complex

$\mathrm{SO}_{2} \quad$ sulfur dioxide

SRS Savannah River Site

STEL short-term exposure limit

TAN Test Area North

TLV threshold limit value 
TSCA Toxic Substances Control Act

TWA . time-weighted average

USFWS U.S. Fish and Wildlife Service

WAC waste acceptance criteria

WERF Waste Experimental Reduction Facility 


\section{ENVIRONMENTAL ASSESSMENT IDAHO NATIONAL ENGINEERING LABORATORY LOW-LEVEL AND MIXED WASTE PROCESSING}

\section{INTRODUCTION}

This Environmental Assessment (EA) has been prepared by the U.S. Department of Energy (DOE) to identify and evaluate the potential environmental impacts of a proposed action to expand mixed low-level waste (MLLW) (waste materials containing both low-level radioactive and hazardous constituents) treatment operations at the Idaho National Engineering Laboratory (INEL) Waste Experimental Reduction Facility (WERF), and to use commercial facilities for supplemental low-level waste (LLW) volume reduction. The proposed action would enable DOE to provide effective longterm management of INEL MLLW and LLW using methods that are technically and environmentally sound and responsive to regulatory and policy requirements.

The EA was prepared in accordance with the requirements of the National Environmental Policy Act (NEPA), as implemented by the Council on Environmental Quality regulations [40 Code of Federal Regulations (CFR) 1500-1508] and DOE NEPA regulations [10 CFR 1021]. It will aid in determining if a "finding of no significant impact" should be issued or an Environmental Impact Statement (EIS) should be prepared prior to decisionmaking regarding implementation of the proposed action.

\subsection{Background}

The INEL is a DOE nuclear research and defense program facility located near Idaho Falls, Idaho (Figure 1). It was established in 1949 for constructing, testing, and operating nuclear facilities. Current INEL activities include reactor operations, treatment and storage of reactor fuel and radioactive waste, and environmental restoration.

The INEL generates LLW and MLLW while performing energy, defense, and environmental restoration missions. Prior to $1982, \mathrm{LLW}$ and MLLW were disposed of directly by shallow land burial at the INEL Radioactive Waste Management Complex (RWMC). In 1982, WERF was established to develop and demonstrate $L L W$ volume reduction and stabilization processes.

WERF is a Resource Conservation and Recovery Act (RCRA) interim status facility located in a decontaminated and decommissioned building formerly occupied by the Power Burst Facility nuclear reactor (see Figure 1). The proposed mission of WERF is to develop and apply safe, efficient, production-scale methods for volume reduction and stabilization of LLW and MLLW. Volume reduction is accomplished by compaction, metal size reduction, and incineration with ash stabilization. Waste processing support components include a waste storage building and asphalt pads, liquid waste blending and feed equipment, waste repackaging areas, and administrative support facilities. WERF began metal sizing operations in 1982, LLW incineration in 1984, and LLW compaction and ash stabilization in 1987. Most of the waste processed at WERF is LLW; however, 


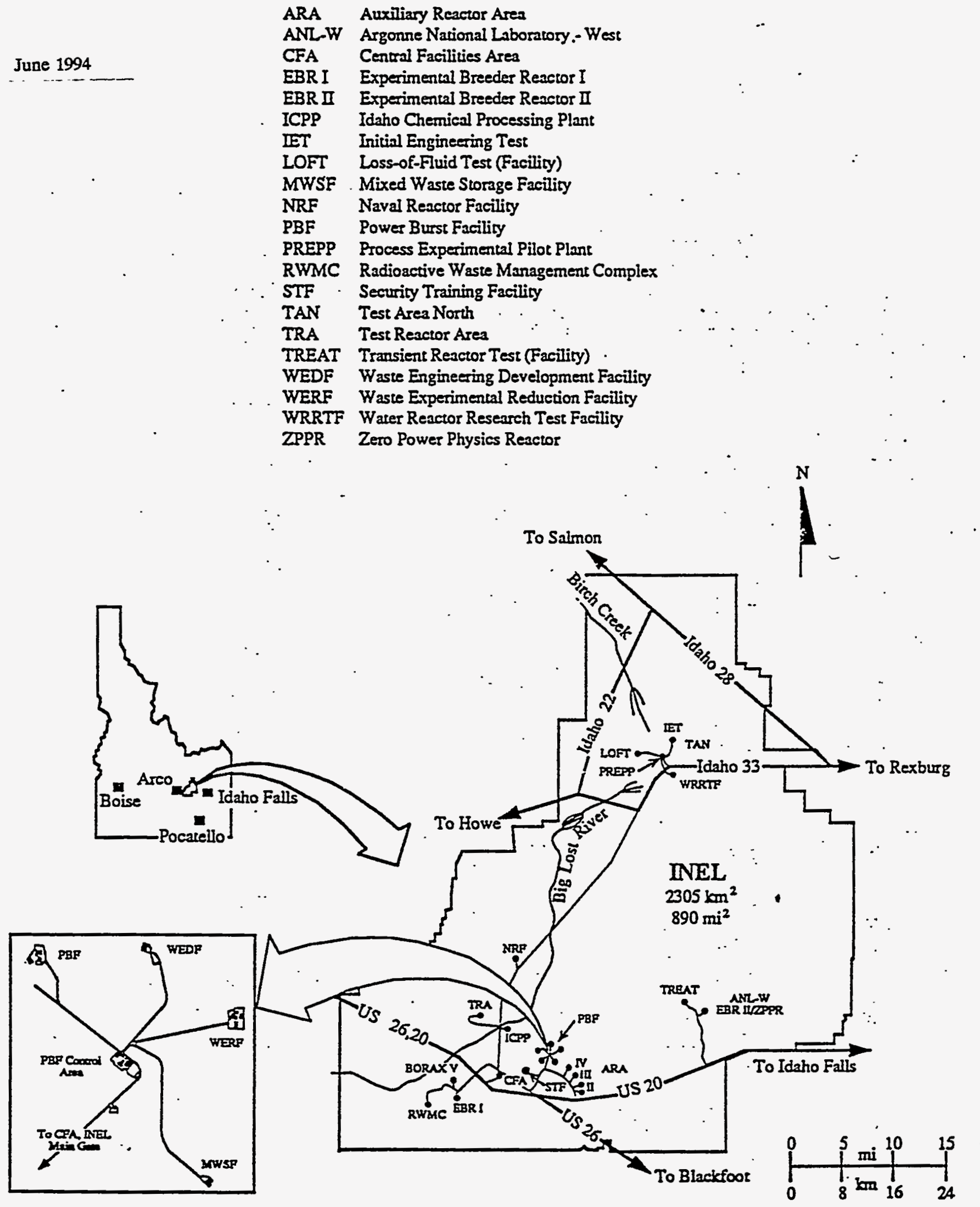

Figure 1. INEL and facility locations. 
eight MLLW incineration campaigns were performed during 1989 and 1990. The MLLW campaigns were conducted using solid waste feedstocks that exhibited reactive and/or toxic metal characteristics identified in the Environmental Protection Agency (EPA) Hazardous Waste Categories D003 through D011 (40 CFR 261.23-24). The campaigns treated approximately $26 \mathrm{~m}^{3}$ of WERF flyash from previous campaigns, $11 \mathrm{~m}^{3}$ of waste from the Mixed Waste Storage Facility, and $28 \mathrm{~m}^{3}$ of classified waste from offsite. These campaigns were conducted efficiently and there were no unusual events or system upsets.

A WERF waste stream flow diagram is shown in Figure 2, and the facility layout is depicted in Figure 3. Prior to sending waste to WERF, waste generators provide required data on waste characteristics to verify compliance with appropriate waste acceptance criteria (WAC). The WAC prescribe specific requirements to ensure proper waste management and protection of health, safety, and the environment. With regard to radioactivity, WERF can accept only contact-handled waste. The waste packages can be handled directly by workers and do not require special shielding or remote handling. Waste that meets the WAC is transported to WERF in metal or wooden boxes, cardboard boxes loaded into cargo containers, or metal drums. The waste containers are stored on asphalt pads or inside the WERF waste storage building, depending on the waste form, packaging, and designated treatment or volume reduction process.

Waste compaction and sizing are performed in the sizing/compaction building on LLW only. Solid LLW is compacted in a $180,000-\mathrm{kg}$ hydraulic press resulting in volume reductions of approximately 5:1. Containers of bagged, compactible LLW are transported from storage by forklift to the compactor area where the waste is transferred to metal compaction boxes and compacted. Full boxes are removed from the compactor by forklift, a lid is installed and locked in place, and the box is removed for transport to and disposal at RWMC.

Metallic waste requiring size reduction is transferred from storage into the sizing area. Coated materials are stripped and the metal is cut into smaller pieces using plasma-arc, air-arc, and oxyacetylene cutting systems. After sizing, the waste is repackaged in approved waste disposal containers. Sizing results in typical volume reductions of 5:1.

Solid incinerable waste is bagged by the generators, packaged in cardboard boxes, and placed in cargo containers for transportation to WERF. At WERF, waste boxes are transported from cargo containers to the WERF incinerator area on pallets. The incineration process includes evaluating each box by radiographic inspection, weighing, and radiation monitoring. The boxes are then burned in a dual-chambered, controlled-air incinerator. Bottom ash is collected for stabilization or direct disposal, and fly ash is collected from the offgas filtration system for stabilization.

Liquid waste is pumped into the incinerator through injection nozzles designed to provide highefficiency combustion by atomizing waste into fine droplets. Liquid waste that cannot be pumped through injection nozzles may be absorbed onto combustible media in boxes prior to incineration.

Residues from incineration (fly ash, bottom ash, and sizing facility baghouse dust) are stabilized in cement by pouring cement and water into drums that are partially filled with ash. The drums are tumbled to mix the contents, cured, and sealed for transport and disposal. Incineration results in typical waste volume reduction ratios of 200:1 (incineration only) or 70:1 if the ash is stabilized. 


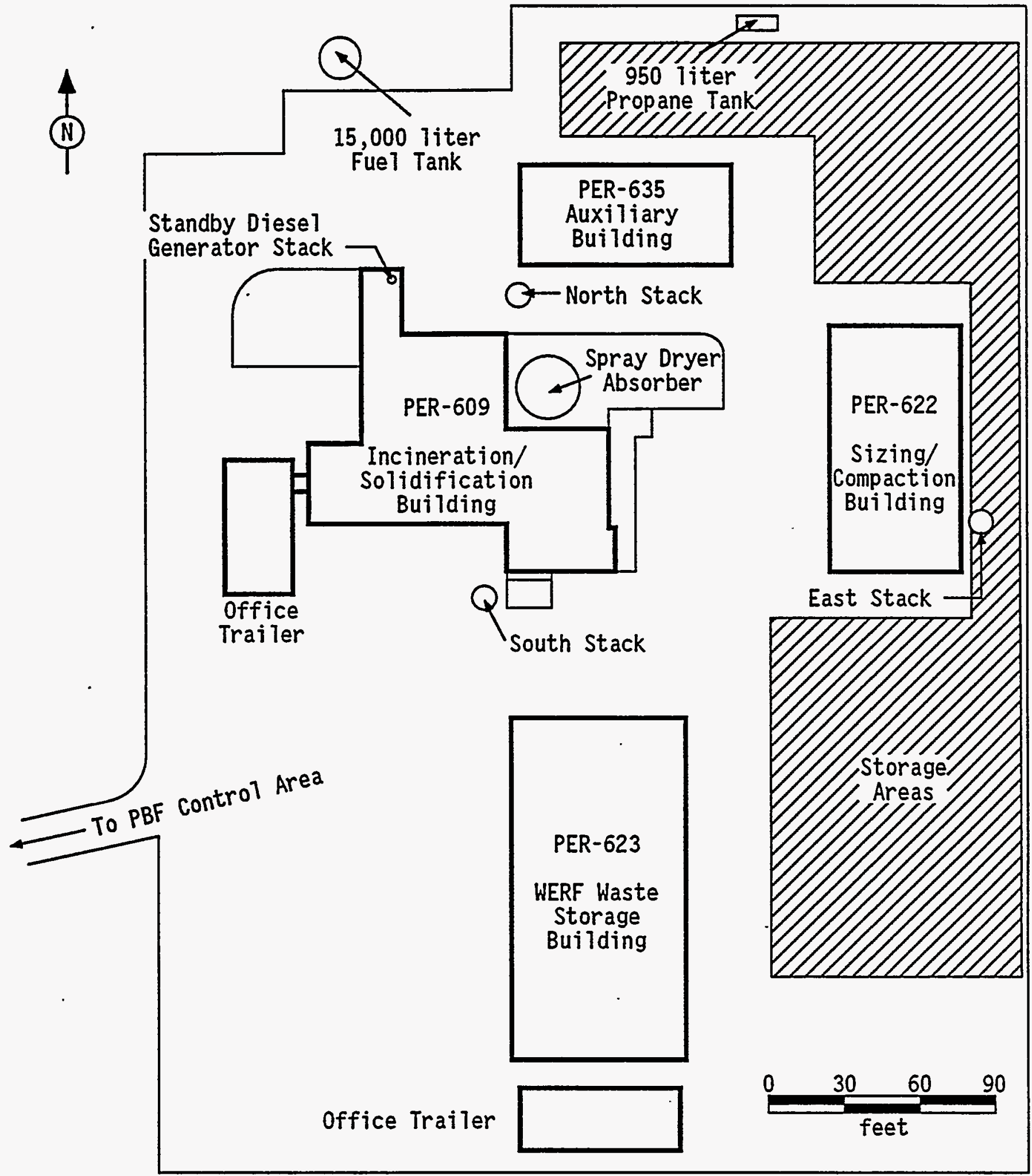

Figure 3. Layout of WERF facilities (approximate scale). 
WERF has been an essential component of INEL's waste management program since 1982. For example, in 1988, 1989, and 1990 , WERF processed $3,000 \mathrm{~m}^{3} ; 2,700 \mathrm{~m}^{3}$; and $3,200 \mathrm{~m}^{3}$; respectively, of solid $L L W$, and reduced the total volume by an average of 10:1 (DOE, 1988). WERF operations were suspended in February 1991 to upgrade safety documentation, operating procedures, and management systems.

\subsection{Purpose of Agency Action}

The purpose of the proposed DOE action is to provide RCRA compliant treatment capability for INEL MLLW and to reduce the volume of LLW before disposal. The action would reduce the volume and toxicity of MLLW and comply with RCRA regulations (40 CFR 268) and Idaho Hazardous Waste Management Act requirements. In addition, the action would support continued compliance with the following DOE Order 5820.2A requirement: "Waste treatment techniques such as incineration, shredding, compaction, and solidification or other RCRA approved treatments to reduce volume and provide more stable waste forms shall be implemented as necessary to meet [disposal facility] performance requirements." The proposed action would also aid DOE in fulfilling its responsibility for providing long-term management of MLLW and LLW using methods that are technically and environmentally sound.

\subsection{Need for Agency Action}

DOE needs to treat MLLW to comply with RCRA requirements for storage and disposal, and to provide support for ongoing INEL activities that generate MLLW. DOE also needs LLW volume reduction support to supplement existing treatment capabilities and to provide technologies not presently available at the INEL (e.g., metal melting and decontamination). Both parts of the proposed action would support compliance with DOE Order 5820.2A requirements for waste volume reduction and stabilization.

Disposal of MLLW is constrained because of a shortage of treatment facilities and disposal sites. To dispose of MLLW in accordance with RCRA land disposal restrictions (LDRs), the hazardous constituents must be treated unless the disposal site(s) can demonstrate to EPA that migration of hazardous constituents in the untreated waste will not occur. No site has been approved for disposal of MLLW without treatment. Certain types of MLLW must be incinerated to comply with the EPA's technology-based treatment standards (40 CFR 268).

MLLW is currently stored at various INEL facilities. The current inventory includes approximately $72 \mathrm{~m}^{3}$ of incinerable MLLW. Approximately 60 days of production-scale incineration at WERF would be required to treat the existing inventory of MLLW. Based on LDR requirements, this waste may be stored solely for the purpose of accumulating quantities sufficient to facilitate treatment. Currently, WERF is the only operable DOE facility capable of incinerating INEL MLLW; commercial incineration of INEL MLLW is not available. Future INEL activities are expected to generate approximately $48 \mathrm{~m}^{3}$ of incinerable MLLW each year. Treatment capacities must be available for this newly generated MLLW. 
WERF operations were suspended in February 1991 to upgrade safety documentation, operating procedures, and management systems. The documentation is being revised to reflect actual WERF configurations and to comply with recently issued DOE orders. The documentation and facility operational readiness will be evaluated and approved by DOE and contractor oversight teams before waste reduction operations are resumed. A large inventory of LLW requiring volume reduction has accumulated since WERF operations were suspended. The accumulating inventory of LLW needing volume reduction has prompted the INEL to review alternatives for managing this waste. The LLW is presently stored outside WERF on asphalt pads and at generator sites in plywood boxes or cargo containers. Storage space at WERF is limited and is near capacity. Expeditious LLW processing and disposal would minimize the risk of waste storage container deterioration and radiological releases, and maintain as low as reasonably achievable radiation fields and worker doses at WERF. Volume reduction is also needed to comply with the RWMC WAC (DOE, 1991a) and to conserve LLW disposal space. The proposed action would facilitate volume reduction of the accumulated LLW inventory and newly generated LLW at WERF or at commercial facilities. LLW volume reduction operations would continue at WERF during approximately 200 days each year. After treatment of the existing MLLW inventory, approximately 40 days per year would be used for MLLW treatment based on current generation rates.

Table 1 shows the inventory (through September 1993) and INEL generation rates for waste requiring volume reduction/treatment processes. Future generation rates may be less because of waste minimization and pollution prevention efforts.

\subsection{Scope of the EA}

This EA identifies and evaluates the potential environmental impacts of expanding MLLW treatment operations at WERF from demonstration-level activities to production-scale campaigns. It also evaluates the potential environmental impacts of using commercial facilities for supplemental LLW volume reduction. The proposed action would expedite processing of the INEL LLW inventory, provide treatment capabilities not available at WERF (e.g., metal decontamination and melting), and provide a means for complying with RCRA regulations for MLLW. The WERF incinerator restart and resumption of previous LLW compaction, sizing, and incineration/stabilization operations are considered to be routine, ongoing activities (the no action alternative) separate from the proposed action.

Table 1. Inventory of LLW and MLLW through September 1993, and INEL generation rates.

\begin{tabular}{lcc}
\hline \multicolumn{1}{c}{ Type of waste } & Waste inventory $\left(\mathrm{m}^{3}\right)$ & Generation $\left(\mathrm{m}^{3} / \mathrm{month}\right)$ \\
\hline Compactable LLW & 2,000 & 113 \\
Incinerable LLW & 5,000 & 142 \\
Sizable LLW & 2,500 & 85 \\
Total LLW & 9,500 & 340 \\
Incinerable MLLW & 72 & 4 \\
\hline
\end{tabular}


The impact analysis in Section 4 assumes that WERF would operate at full capacity incinerating MLLW with the maximum allowable concentration of radionuclides. Because MLLW includes both hazardous and LLW components, the impact of incinerating LLW is bounded by this analysis. The INEL ships its nonradioactive hazardous waste offsite for treatment and disposal and has no plans to treat nonradioactive hazardous waste at WERF. Cumulative impacts of full-scale LLW compaction and sizing are also evaluated.

Commercial incineration alternatives for MLLW were investigated, but were not considered viable because permit or WAC constraints would prohibit the few existing commercial treatment facilities from accepting INEL MLLW. Potentially viable alternatives to the proposed action include:

- No action (continue to store INEL-generated MLLW and use WERF to incinerate, compact, and size LLW)

- Treat MLLW by methods other than incineration and continue use of WERF to incinerate, compact, and size LLW

- Dispose of LLW without volume reduction and continue to store MLLW

- Construct and operate a new MLLW incinerator and continue to incinerate, compact, and size LLW at WERF

- Treat MLLW at another DOE incinerator and continue to incinerate, compact, and size LLW at WERF.

\subsection{EA Justification}

In determining the appropriate level of NEPA documentation for the proposed action, DOE reviewed NEPA implementing regulations in 10 CFR 1021 that identify actions normally requiring an EA (but not necessarily an EIS), and actions normally requiring an EIS. Section 1021.400(d) states, "if a DOE proposal is not encompassed within the classes of actions listed in the appendices to Subpart D, or if there are extraordinary circumstances related to the proposal that may affect the significance of the environmental effects of the proposal, DOE shall either: 1) prepare an EA and, on the basis of that EA, determine whether to prepare an EIS or a "finding of no significant impact"; or 2) prepare an EIS and record of decision."

The following Subpart D classes of actions were carefully considered for applicability to the proposed action:

- Appendix C, "Classes of actions that normally require EAs but not necessarily EISs" [C15. Siting, construction (or expansion), and operation of research and development incinerators/nonhazardous waste incinerators]. 
- Appendix D "Classes of actions that normally require EISs" (D12. Siting, construction and operation of incinerators other than research and development incinerators for nonhazardous waste).

The proposed action does not clearly fit either of the Subpart D typical classes of actions. The proposed action does not involve a research and development/nonhazardous waste incinerator, or siting/construction of an incinerator. Furthermore, the following extraordinary circumstances may affect the environmental significance of the proposed action:

- The proposed action would take place at existing facilities and would not include construction activities; therefore, there would be no construction impacts.

- WERF has routinely incinerated LLW since 1982 and completed eight MLLW campaigns in 1989-1990, with no significant adverse environmental effects. The proposed action would be similar to past routine operations and is not expected to cause adverse environmental effects.

- The existing inventory of incinerable MLLW is less than $2 \%$ of the total incinerable waste inventory. The incinerable MLLW generation rate is less than $3 \%$ of the incinerable LLW generation rate. Although WERF incineration will continue to operate year round (240 days), MLLW incineration would require a maximum of 60 days to reduce the current inventory and approximately 40 days per year after reduction of current inventory.

The proposed action is not encompassed within the classes of actions listed in the appendices to Subpart D, and there are extraordinary circumstances related to the proposal that may affect the significance of the environmental effects of the proposal. Accordingly, DOE prepared this EA. On the basis of the EA, DOE will determine whether to prepare an EIS or to issue a "finding of no significant impact."

\subsection{Relationship to Other NEPA Reviews}

On October 22, 1990, DOE announced (55 FR 42633-8) that its Office of Environmental Restoration and Waste Management (EM) intends to prepare a Programmatic EIS (PEIS) on its proposed Integrated Environmental Restoration and Waste Management Program (ER\&WM). This program is expected to provide a broad, systematic approach to addressing waste management practices. The EM PEIS will discuss a range of alternatives for existing and proposed activities and will address DOE complex-wide issues associated with long-term ER\&WM policies and practices.

In addition to the PEIS, DOE has issued a Notice of Intent to prepare an EIS addressing existing and proposed INEL ER\&WM activities (57 FR 45773). The INEL ER\&WM EIS will evaluate a range of alternatives regarding INEL waste management and treatment. The INEL ER\&WM EIS will include the cumulative impacts of past, present, proposed, and reasonably foreseeable INEL activities. The Notice of Intent explains that the NEPA documentation and decision for the proposed WERF operations/commercial LLW volume reduction (as well as other proposed actions) are expected to precede completion of the ER\&WM EIS process. It also explains 
that WERF activities (either the proposed action or alternatives) will be assessed as part of the baseline/no action alternative (including any decontamination or phase-out of treatment at the WERF incinerator).

There is an immediate need for the proposed action described in this EA to meet current and near-term waste treatment and management needs at INEL. This action will be required regardless of how DOE decides to meet long-term INEL waste treatment needs pursuant to the INEL ER\&WM EIS, and regardless of how DOE decides to implement long-term department-wide waste management programs pursuant to the PEIS. Furthermore, the WERF incinerator is an existing facility that has treated both LLW and MLLW (on an experimental basis). The proposed supplemental LLW volume reduction would occur in operating commercial facilities, and would not require a large capital investment or commitment of resources.

The proposed action at WERF does not include processing LLW or MLLW from sources other than INEL, with the exception of very limited quantities $\left(<5 \mathrm{~m}^{3} / \mathrm{yr}\right)$ explained further in this document. The use of WERF as a regional incinerator to process LLW or MLLW from non-INEL sources, such as other DOE facilities, is not within the scope of the proposed action. Such an action (if proposed or as an alternative) would be addressed in the EM PEIS, the INEL ER\&WM EIS, and/or other appropriate NEPA documentation. 


\section{PROPOSED ACTION AND ALTERNATIVES}

The following sections describe the proposed action and alternatives to the proposed action. The proposed action includes expanding the MLLW processing capability at WERF from the current demonstration-level activities to production-scale treatment and using commercial offsite facilities for supplemental LLW volume reduction.

\subsection{Proposed MLLW Incineration}

Treatments identified for MLLW at WERF include incineration and stabilization using existing facilities and procedures. Repackaging of waste form one container to another may also be performed to facilitate solid or liquid incineration. The primary sources of MLLW for treatment are INEL facilities and programs, although limited quantities ( $\left.<5 \mathrm{~m}^{3} / \mathrm{yr}\right)$ of offsite waste may be received and treated. Treatment of offsite waste would be considered nonroutine. The waste would have to comply with the storage facility and WERF WAC developed to ensure compatibility with WERF material storage, handling, and processing capabilities and environmental, health, and safety requirements.

The proposed action would allow DOE to incinerate MLLW containing characteristic hazardous constituents and to dispose of the resulting ash at RWMC as LLW. Ash samples from characteristic MLLW incineration would be analyzed to ensure compliance with RCRA requirements before disposal. If the ash did not qualify for direct disposal as LLW, it would be stabilized and reevaluated for disposal or stored as MLLW.

MLLW containing RCRA listed hazardous constituents would also be treated and the resulting ash would be delisted or placed in storage until MLLW disposal facilities are developed or until future regulations allow disposal. The proposed treatment would comply with EPA's technologybased treatment standards (40 CFR 268).

Under the proposed action, the existing liquid waste injection system would be upgraded to: a) meet the requirements of the National Fire Protection Association for flammable liquid handling (NFPA 30-1990) as defined in 29 CFR 1910.106, and b) allow for the injection of atomized aqueous (low heat value) waste into the WERF lower combustion chamber. This upgrade would enhance safety and liquid waste feed controls so the thermal capacity of the incinerator (5 million BTU/hr) or the RCRA hydrochloric acid $(\mathrm{HCl})$ emission limit of $1.8 \mathrm{~kg} / \mathrm{hr}$ would not be exceeded. This limit is independent of offgas moisture content. $\mathrm{HCl}$ emissions would be controlled by adjusting the feed rate of chlorinated compounds to the incinerator. After the proposed facility modification documentation and upgrades are completed, a trial burn would be conducted to meet RCRA Part B permitting requirements and to verify compliance with emission standards established by the State of Idaho Permit to Construct.

To support proposed operations, some waste may need to be repackaged from drums into other containers (e.g., cardboard boxes) in order to be fed into the incinerator. Liquid wastes may be blended into other drums in order to adjust the heating value of the waste. Fugitive emissions from repackaging operations would be exhausted through HEPA filters to the existing incinerator stack. 
June 1994

\subsection{Proposed Commercial LLW Treatment}

The proposed action includes using licensed and permitted commercial LLW treatment facilities for supplemental LLW volume reduction. To implement this part of the action, INEL would award one or more contracts for LLW transportation, processing (e.g., compacting, incinerating, sizing, melting, decontaminating, stabilizing), and returning processed waste materials to the INEL. The contract(s) would establish specific INEL and commercial vendor responsibilities and treatment standards. It is anticipated that a portion of the accumulated inventory and a portion of the newly generated LLW would be processed at commercial facilities. The actual distribution of waste between WERF and commercial processing facilities has not been determined. However; the impact analyses in Section 4 assume full-scale WERF operations that would conservatively bound processing all newly generated INEL LLW and MLLW at WERF. Transportation impact analyses conservatively bound transporting all of the LLW to commercial facilities.

Proposed commercial processing would include the following activities:

- INEL personnel would load packaged waste into commercial shipping containers

- The waste would be transported to the processing facility by a commercial vendor

- At the commercial facility, the waste would be inspected and surveyed to verify the waste properties

- The waste would then be processed for volume reduction (processing of ash may also be required in order to meet RCRA/contractual treatment standards)

- The processed LLW (e.g., ash, compacted waste) would be packaged, characterized, and returned to INEL for disposal in accordance with the RWMC WAC.

Licensed commercial carriers would provide transportation, and the commercial transporter or processor would provide waste transportation containers. Prior to loading the LLW, containers would be inspected for damage and surveyed for radiation and contamination. Noncompliant containers would be rejected and returned to the vendor. Waste would be transferred to acceptable containers at WERF or other appropriate staging areas by INEL personnel using established procedures, equipment, and monitoring. If contamination is detected during loading, the container would be decontaminated prior to shipment. On the day of the shipment, the container exterior would again be inspected for damage, surveyed for radiation and contamination, and placarded according to U.S. Department of Transportation requirements. Before departure, documentation would be reviewed for completeness and accuracy and blocking, bracing, and tie-downs would be inspected for appropriate application. Transportation would be conducted in accordance with applicable U.S. Department of Transportation, Nuclear Regulatory Commission (NRC), DOE, and EPA regulations and the requirements of the states and local jurisdictions through which the waste would be transported. 
Transporting LLW is a routine activity. Approximately two million shipments of non-DOE radioactive materials are made each year in the United States (Wolfe, 1984). Between 162 and 180 shipments would be required to transport all of INEL's projected LLW inventory (through September 1993) to a commercial processing facility (depending on load weight limits). Between 70 and 78 additional shipments would be required each year if all of the expected future LLW is transported to commercial processors. The proposed shipments would constitute a small increase in the total number of U.S. commercial shipments.

The commercial facility would be responsible for complying with applicable environmental regulatory requirements. Treatment operations would be required to be conducted in accordance with NRC, EPA, host state, and other pertinent licenses, permits, statutes, and regulations. Prior to awarding a contract(s), the vendor(s) would be required to furnish evidence of state and federal permits for their processing operations. INEL personnel would audit the vendor(s) for environmental, quality, health, and safety compliance prior to awarding the contract(s), and periodically during the life of the contract(s).

LLW incinerator bottom ash is a potential RCRA characteristic hazardous waste because of the presence of heavy metals. The commercial vendor would provide secondary ash treatment if necessary, and certify that the final waste form meets the EPA's Toxicity Characteristic Leaching Procedure criteria. The final waste would then be returned to INEL for verification of the commercial processor's certification and disposal at the RWMC in accordance with DOE Order 5820.2A requirements.

The commercial vendor may take ownership and be responsible for some waste processing residues such as baghouse fly ash, scrubber effluent, and final filtration components. Vendors retaining these materials would be required to provide treatment and/or disposal in accordance with NRC, state, and EPA requirements. The vendors' compliance with applicable requirements would be verified by periodic audits performed by INEL management and environmental oversight organizations. Audits would be performed as specified in DOE Order 5480.1B, EPA's Environmental Auditing Policy Statement (51 FR 25004), and INEL Standard Operating Procedures.

If waste that does not comply with the vendor's WAC is shipped to the vendor, it would be sorted, repackaged, and returned to INEL. Waste examination and analysis activities at the vendor's facility would be required to comply with their permits and licenses and would also be verified by periodic audits.

\subsection{WERF Facilities and Incineration Process}

The WERF complex includes: 1) the main WERF building, which houses the waste incineration, waste stabilization, and facility support operations and offices; 2) the sizing building, which houses size reduction and waste compaction operations; 3 ) the auxiliary building, which is used for tool and equipment storage; and 4) the WERF waste storage building, which would store MLLW when operations commence. The layout of WERF facilities is shown in Figure 3. 
Generators (on or off the INEL site) must ship their MLLW to an INEL waste storage facility prior to the wastes being delivered to WERF for incineration. The WAC for the storage unit must be met prior to shipment. Prior to acceptance at WERF, generator waste data forms, shipping records and manifests, characterization reports, and certification statements are reviewed by WERF personnel. Incinerable waste must meet specifications for package weight, dimensions, total chloride, total fluoride, ash content, heating value, type of package, and viscosity. Items such as pressurized containers, gaseous waste, pyrophorics, explosives, reactive materials, asbestos, incompatible chemicals in the same container, active etiologic agents, polychlorinated biphenyls $\geq 50 \mathrm{ppm}$, and beryllium from sources identified in 40 CFR 61 are excluded by the WERF WAC.

The WERF incinerator has three burners. Two burners (one each in the lower and upper combustion chambers) use fuel oil to preheat the incinerator and provide auxiliary heat as necessary. The third burner (in the lower chamber) is a liquid-waste burner for contaminated fuel oil and other high-heat-value waste. The liquid-waste burner is connected to a drum feed/blending unit used to blend various liquid wastes or to consolidate small volumes to obtain waste with characteristics suitable for incineration.

Solid waste, packaged in cardboard boxes, is fed into the incinerator through a triple door chute system above the lower combustion chamber. During incineration, the lower chamber is controlled to restrict the amount of air available for combustion, resulting in a slow, rolling burn that releases volatile gases but minimizes particulate carryover. Volatile gases released in the lower chamber enter the upper chamber where an auxiliary burner and combustion air blowers supply supplemental heat and excess air ( 90 to $120 \%$ in excess of the stoichiometric requirement) to ensure complete combustion. Liquid waste is fed to the incinerator liquid waste burner through piping connected to the liquid waste blending and feed unit.

Particulate emissions from controlled-air incinerators are much lower than those from other technologies. Low gas velocities in the lower chamber and complete combustion in the upper chamber result in low particulate carryover. A controlled-air incinerator was selected for WERF because of its inherent particulate-control feature. Because most of the radionuclides in INEL LLW and MLLW are in particulate form, this feature helps limit radiological releases to the environment.

To protect the air pollution control system, hot combustion gases undergo a three-stage cooling process prior to filtration. After leaving the upper combustion chamber, the offgas is cooled by mixing with dilution air drawn from within the incinerator room. The gases then flow through a shell and tube heat exchanger and are further cooled. A second stream of dilution air from the WERF basement is mixed with the gas exiting the heat exchanger to cool the exhaust to less than $260^{\circ} \mathrm{C}$ before entering the pollution control equipment. The WERF incinerator uses a baghouse, prefilter, and high-efficiency particulate air (HEPA) filter system for air pollution control. The system is designed to minimize particulate and metal emissions. Gaseous pollutants are controlled by limiting the feed rate of contributing constituents in the waste feed. Filtered offgas is monitored for oxygen, combustible gas, carbon monoxide, radioactivity, and opacity. 
The flyash from waste incineration is periodically transferred from the baghouse to collection hoppers. It is loaded into drums and transported to the WERF stabilization room where it is stabilized with Portland cement. Incinerator bottom ash typically does not require stabilization. Ash would be disposed of at RWMC, or stored in an existing INEL RCRA interim status or permitted RCRA storage facility until it can be transported to a MLLW disposal facility.

The stabilization unit can effectively stabilize a wide variety of wastes. In addition to fly ash, stabilization may also be used as the EPA technology-based treatment standard to treat certain MLLW. Thermoplastic stabilization processes, other than Portland cement (e.g., sulfur polymer cement), are being evaluated for potential future applications. These processes may be applied if they meet appropriate performance criteria.

Solid and liquid MLLW is generated from INEL operations, maintenance, and decontamination and decommissioning activities. Incinerable MLLW is primarily absorbent materials contaminated with hazardous wastes (e.g., spent solvents, aqueous wastes, organic liquids, suspended or dissolved metals, or paint chips). A more detailed discussion of the radioactive and hazardous constituents in the waste is presented in Section 4.

Non-INEL wastes that may be processed at WERF include limited quantities $\left(<5 \mathrm{~m}^{3} / \mathrm{yr}\right)$ of special-case wastes that cannot be treated at the generation sites or at commercial facilities. Receipt and treatment of offsite waste is a nonroutine activity and would be subject to the same criteria for acceptance at WERF as INEL waste.

\subsection{Alternatives to the Proposed Action}

This section includes descriptions of the alternatives to the proposed action. The advantages and disadvantages of the alternatives are addressed in Section 4.4.

\subsubsection{No Action Alternative}

The no action alternative is to continue storing INEL MLLW at INEL and routinely process LLW at WERF. Production-scale treatment of MLLW would not be performed at WERF. Therefore, existing and future generated INEL MLLW (and small quantities of offsite-generated MLLW) would require continued storage.

Through September 1993, approximately $9,500 \mathrm{~m}^{3}$ of LLW would be stored outside in plywood boxes and cargo containers. Depending on staffing levels, volume reduction treatment of this inventory would require 3 to 5 years. After the inventory is processed, the newly generated LLW would be treated as sufficient quantities are accumulated. The existing storage areas for LLW would provide adequate space for waste accumulation for treatment. 


\subsubsection{Treat MLLW by Methods Other Than Incineration and Continue Use of WERF to Incinerate, Compact, and Size LLW}

Incineration is EPA's technology-based treatment standard for most of the MLLW included in the proposed action. Technologies other than incineration may be used if the EPA determines that the technologies achieve an equivalent level of treatment, as addressed in 40 CFR 268.42(a). Information must be submitted to the EPA regional administrator demonstrating that each treatment method would be in compliance with federal, state, and local requirements, and would be protective of human health and the environment. Stabilization and biological or chemical treatments are potential alternatives to incineration; however, extensive research and development would be required to demonstrate that these technologies would meet EPA criteria as defined in 40 CFR 268.43(b).

As described in Section 2.4.1, reduction of the existing inventories of LLW would not begin until WERF resumes operations. The existing inventory is estimated to require 3 to 5 years for processing through WERF (depending on staffing levels).

\subsubsection{Dispose of LLW Without Volume Reduction and Continue to Store MLLW}

This alternative would require continued storage of MLLW, as described in Section 2.4.1, the no action alternative. This alternative would require existing inventories of LLW and newly generated LLW to be disposed of at RWMC without volume reduction or stabilization. Considering the projected LLW inventory of $9,500 \mathrm{~m}^{3}$ and the current $L L W$ generation rate, the disposal capacity for the RWMC would be reached in 5 to 7 years. Newly generated waste would be packaged at the generator's facility and shipped directly to RWMC for disposal in the Subsurface Disposal Area.

\subsubsection{Construct and Operate a New MLLW Incinerator and Continue to Incinerate, Compact, and Size LLW at WERF}

This alternative would involve constructing an additional incinerator to provide production-scale treatment of INEL MLLW. The incinerator would treat characteristic and listed hazardous constituents in MLLW. The stabilized ash from characteristic MLLW would be disposed of at RWMC as LLW. The ash from listed MLLW incineration would be delisted or stored in an existing RCRA interim status or permitted storage facility until it could be transported to a MLLW disposal facility. Construction of a new incinerator would allow MLLW to be treated concurrently with WERF LLW processing. MLLW would continue to be stored until the incinerator is operational. After the incinerator is operational, MLLW would be stored for a short time until sufficient quantities are accumulated for incineration; no long-term storage of MLLW would be necessary after the incinerator is operational. The incinerator would require an approved RCRA Part B Permit, including a trial burn, before MLLW treatment operations commence. 


\subsubsection{Treat MLLW at Another DOE Incinerator and Continue to Incinerate, Compact, and} Size LLW at WERF

In addition to WERF, DOE has several existing or planned radioactive waste incinerators at defense program sites throughout the U.S. that could potentially be used for processing some wastes proposed for WERF. Incinerators are located at the Rocky Flats Plant (RFP) in Colorado, Los Alamos National Laboratory (LANL) in New Mexico, and Oak Ridge Reservation (ORR) in Tennessee. Currently, WERF and the Toxic Substance Control Act (TSCA) incinerator at the ORR K-25 site are the only operable incinerators in the DOE system capable of treating many forms of MLLW. The RFP and LANL incinerators are not presently operating. The Savannah River Site (SRS) in South Carolina is planning a new hazardous and mixed waste incinerator. The ORR incinerator is not suitable for beta/gamma-contaminated wastes and is scheduled to operate at or near capacity for onsite wastes. The designated missions and RCRA permits for other DOE incinerators generally prohibit receiving and treating INEL generated wastes. 


\section{AFFECTED ENVIRONMENT}

\subsection{Physical Environment}

INEL is located in southeastern Idaho at the foot of the Lost River, Lemhi, and Beaverhead mountain ranges along the edge of the Eastern Snake River Plain. The topography is generally flat to gently rolling, with elevations ranging from $1,585 \mathrm{~m}$ in the northeast to $1,451 \mathrm{~m}$ in the southwest. WERF, in the southcentral portion of INEL, is located on a gently rolling basalt plain with an elevation of approximately $1,506 \mathrm{~m}$.

Mountain ranges to the west channel prevailing westerly winds into a southwesterly pattern across INEL. Northeasterly winds also are common as a result of cold air draining from, and channeling by, higher terrain north of the INEL.

The area surrounding INEL is classified as a Prevention of Significant Deterioration Class II area, designated under the Clean Air Act as an area with reasonably or moderately good air quality while still allowing moderate industrial growth. Craters of the Moon Wilderness Area, which is 49 $\mathrm{km}$ from INEL, is classified as a Prevention of Significant Deterioration Class I area, and is the nearest area to INEL where additional degradation of local air quality is severely restricted.

A summary description of the geology, soils, seismology, hydrology, water resources, air quality, meteorology, and climate of the INEL area can be found in Berry and Petty (1990).

\subsection{Ecology}

The Eastern Snake River Plain is a shrub-steppe biotic community. INEL vegetation is representative of a cool desert ecosystem. The Big Lost River and associated playas provide limited aquatic habitat during some years (Bowman et al., 1984).

There are no known species listed as endangered or threatened by the U.S. Fish and Wildife Service (USFWS) (50 CFR 17.11, 17.12) residing year-round on the INEL and no known critical habitats (Reynolds et al., 1986; Lobdell, 1992). Preliminary national wetlands inventory maps indicate the possible presence of several small excavated wetlands within $1.6 \mathrm{~km}$ of WERF. None of these wetland areas are located within the WERF boundary and no impacts are anticipated as a result of existing or proposed WERF operations.

The USFWS has determined that the bald eagle is the only animal observed on the INEL that is listed as endangered. Bald eagles winter on or near portions of the INEL. The ferruginous hawk, long-billed curlew, Townsend's big-eared bat, loggerhead shrike, and pygmy rabbit may be found on the INEL and are candidates for the proposed list of threatened and endangered species (Lobdell, 1992). In addition, the merlin, osprey, Swainsons hawk, burrowing owl, whitefaced ibis, and bobcat are listed as species of special concern in Idaho (Moseley and Groves, 1992). One plant species known to exist on the INEL, the painted milkvetch, is a candidate for the list of threatened and eridangered species (Lobdell, 1992). Other plant species listed as sensitive by the U.S. Forest Service 
and/or Bureau of Land Management include the Lemhi milkvetch, plains milkvetch, thistle milkvetch, wing-seed evening primrose, nipple cactus, large-flowered Gymnosteris, spreading gilia, king's bladderpod, and tree-like Oxytheca (Lobdell, 1992). None of the endangered, threatened, or sensitive species have been observed near WERF.

\subsection{Socioeconomics and Cultural Resources}

There are no permanent residents at INEL. Communities near INEL include Idaho Falls, Blackfoot, Pocatello, Arco, and Atomic City with 1990 populations of 43,929, 9,646, 46,080, 1,016, and 25, respectively (U.S. Department of Commerce, 1990). The nearest community to WERF is Atomic City, located approximately $12.7 \mathrm{~km}$ to the south.

The work force at INEL varies depending on the levels of construction and research being conducted at each facility. In May 1992, INEL employed approximately 8,383 persons at the site. There are approximately 44 people working at WERF. Other employees work at Idaho Falls facilities, for a total INEL work force of approximately 12,451 .

Intensive archaeological surveys of all areas within the Power Burst Facility perimeter fence and in a $100-\mathrm{m}$ wide zone surrounding the facility fence have demonstrated that the area is archaeologically sensitive. These surveys, conducted in 1984 and 1985 (Reed et al., 1987), resulted in the recording of 48 prehistoric resources that are potentially eligible to the National Register of Historic Places (NRHP). Impacts to these sensitive resources that would result from proposed INEL projects must be mitigated by additional data collection in advance of all ground disturbing activity. Two significant archaeological resources are located in the vicinity (100-m radius) of WERF. The resources included scattered prehistoric stone tools and fragments that are indicative of short-term, prehistoric hunting activities. In addition, WERF's scientific historical significance for its contributions to the U.S. Nuclear Program will require evaluation if scheduled for renovation or demolition. Other facilities within the Power Burst Facility complex may also be NRHP eligible.

The proposed action is in an existing facility and does not include any soil disturbing activities. Impacts to known archaeological resources are not anticipated. However, should the proposed action appear to threaten any resource, either historic or prehistoric, it is DOE policy to temporarily halt activities and contact the INEL Cultural Resource Management Office to assess the resource. Depending on the potential significance of the resource, the State Historic Preservation Office and, if applicable, the Shoshone-Bannock Tribe may be consulted to determine a suitable mitigation plan.

\subsection{Land Use}

INEL was established in 1949 for nuclear energy research and defense support activities. INEL consists of approximately $2,305 \mathrm{~km}^{2}$, mostly in Butte County but also extending into Bingham, Bonneville, Jefferson, and Clark counties. WERF lies entirely within Butte County. Since 1982, WERF has been dedicated to developing, demonstrating, and implementing LLW and MLLW volume reduction techniques. The proposed action is consistent with existing WERF and INEL land uses. 


\subsection{Background Radiation}

Radiation in the vicinity of INEL consists of natural background radiation from cosmic, terrestrial, and internal body sources. Additional background sources of radiation are nuclear weapons test fallout, consumer and industrial products, and building materials. These sources result in an estimated total effective dose equivalent (EDE) to an average member of the public residing in the vicinity of INEL of $350 \mathrm{mrem} / \mathrm{yr}$ (DOE, 1991b). The INEL added a potential $1.0 \mathrm{E}-03 \mathrm{mrem} / \mathrm{yr}$ $(0.0003 \%)$ to the total background EDE (DOE, 1991b). The background collective EDE (population dose) within an $80-\mathrm{km}$ radius of the INEL operations center is approximately $4.24 \mathrm{E}+04$ personrem/yr (DOE, 1991b). INEL operations added a calculated 4.0E-02 person-rem/yr in 1990 $(0.00009 \%)$ to the estimated total collective EDE (DOE, 1991b). A hypothetical offsite resident near the INEL boundary received an average 5.4E-02 mrem per year for the period of 1980 to 1989 (DOE, 1991c). 


\section{ENVIRONMENTAL IMPACTS OF THE PROPOSED ACTION AND ALTERNATIVES}

This section describes potential environmental impacts of the proposed action and alternatives. If the proposed action is implemented, activities would be limited to existing facilities. A WERF modification would be required to allow for injection of an atomized aqueous waste stream into the incinerator lower chamber. The installation would be performed within the WERF incinerator/stabilization building and may use an existing incinerator access port. Installation work would be similar to many routine maintenance and modification actions at WERF.

A detailed analysis of potential impacts from processing INEL-generated LLW at commercial facilities is not presented in this EA because specific commercial facilities and processes have not been selected. Processing the INEL LLW waste at commercial facilities would result in emissions and impacts at rates that already occur at these facilities from their normal operations. Based on review of potentially qualified vendors, DOE does not expect that the INEL material would constitute a significant change in the overall level of operations of any likely vendor. Commercial LLW incinerators and processing facilities must operate within federal and state regulatory limits. EPA's National Emission Standards for Hazardous Air Pollutants (NESHAP) (40 CFR 61 Subpart $\mathrm{H})$ require that radiological exposure from ambient air emissions from a DOE facility be less than $10 \mathrm{mrem} / \mathrm{yr}$ EDE to a member of the public. WAC, process controls, and monitoring would ensure that air emissions from the commercial facility would be within acceptable standards and license restrictions. The facility must observe applicable requirements of 40 CFR 61 Subpart I, such as monitoring the radiological effluents or proving compliance with the standard by using an approved modeling code. In addition, NRC requires an approved radioactive materials license for the operational phase of the facility prior to startup. The license or permit would embody the standards in 10 CFR 20, which cover worker safety, restricted and unrestricted area (onsite or offsite) radiation levels, and effluent limits. The WAC would be based on standards for workers and limits for unrestricted areas.

\subsection{Operational Impacts of Proposed Action}

All aspects of the proposed action include provisions to protect WERF and other INEL personnel and members of the public. WERF modifications and normal operational activities would proceed according to Occupational Safety and Health Act (OSHA) regulations (29 CFR 1910 and 1926). The work environment is monitored and personnel and area exposure monitoring data are obtained to verify that workplace air contaminant levels are below those prescribed by the American Conference of Governmental Industrial Hygienists (ACGIH), OSHA, and applicable DOE standards. Worker exposure to radioactivity would be as low as reasonably achievable and below the DOE radiation protection standards for occupationally related external and internal exposures. WERF operating personnel would be qualified hazardous material and radiation workers.

Primary impacts from WERF operations would be from airborne emissions of radionuclides (from incinerating, stabilizing, compacting, and sizing), hazardous materials, and criteria pollutants. There are two emission points for these activities: the WERF east stack exhausts ventilation air from 
the compaction and sizing building, and the north stack discharges incinerator offgas and ash stabilization room ventilation air from the incineration/stabilization building. Offgas and ventilation air at both buildings are processed through a baghouse, prefilter, and HEPA filter before being discharged to the atmosphere. A preventive maintenance program ensures that all HEPA filters are routinely tested for efficiency to avoid failure. Differential pressure measurements, flow measurements, and continuous, stack sampling monitor any degradation of the filtration system. Additionally, an isokinetic stack sampling system monitors actual stack emissions of radioactive material.

Ventilation air from the incinerator room is HEPA filtered before being exhausted to the WERF south stack (shown in Figure 3). The south stack formerly exhausted the compactor room in the incinerator building; however, as part of WERF upgrades, the compactor was moved to the sizing/compaction building. The potential for radiological emissions from the south stack has been analyzed and this stack is exempt from 40 CFR 61 Subpart $H$ monitoring requirements; however, for process control purposes, a non-isokinetic sampling system is used to monitor radioactive particulates.

\subsubsection{Impacts from Waste Incineration}

This EA is intended to provide a reasonable upper bound to potential impacts; therefore, the source term for the WERF incinerator is based on conservative assumptions. For radionuclides, a maximum annual release for each constituent was developed. For hazardous waste constituents, feed rates were determined based on the maximum possible incinerator capacity. Ambient concentrations resulting from releases were calculated and compared to occupational exposure and other appropriate limits. Incineration rates of chlorinated hydrocarbons are governed by the release limit for $\mathrm{HCl}$ ( 40 CFR 264), which is formed during incineration of chlorinated compounds. The incinerator is assumed to operate 240 days per year. Approximately 40 days would be used for MLLW incineration based on current generation rates; the remainder would be for LLW. If MLLW generation rates increase, additional treatment time would be required. The impact analysis in this section conservatively assumes that all incinerated waste is MLLW.

Combustion offgases from the incinerator are cooled using an air-to-air heat exchanger supplemented by dilution. These gases then pass through a baghouse filter system, prefilters, and HEPA filters prior to being discharged from the WERF north stack. The HEPA filter system is tested and certified to provide a minimum particulate removal efficiency of $99.97 \%$ for particulates $0.3 \mu \mathrm{m}$ ( 0.3 millionths of a meter). During incineration of MLLW, in accordance with RCRA permits, carbon monoxide levels would be continuously monitored to ensure proper combustion efficiency of the incinerator.

Administrative and mechanical controls would ensure that incinerator releases are within the bounds presented in this EA. A burn plan would be developed prior to incinerating waste, taking into consideration detailed waste information provided by waste generators, and release limits described in the following sections. Monitoring systems for both radiological and nonradiological emissions would verify that the incinerator and support systems are operating properly. 
4.1.1.1 Radiological Impacts. INEL is subject to $40 \mathrm{CFR} 61$ Subpart $\mathrm{H}$, which limits radiological releases from DOE facilities to an EDE of $10 \mathrm{mrem} / \mathrm{yr}$ at the nearest site boundary. EPA determined that this level of exposure $(10 \mathrm{mrem} / \mathrm{yr})$ would result in a lifetime risk of contracting fatal cancer for an individual exposed for 70 years of less than $1 \mathrm{E}-04$, or one in ten thousand. Additionally, if a single stack or vent within a facility has the potential to exceed $0.1 \mathrm{mrem} / \mathrm{yr}$ without taking into account pollution control equipment, continuous monitoring is required. The WERF east and north stacks are required to comply with the monitoring requirements in 40 CFR 61 Subpart H. The monitoring systems have been installed and are operational.

Radionuclide distributions expected in wastes were derived, for many of the nuclides, from analysis of fly ash from previous incinerator campaigns (Atwood, 1992). Other nuclides were added to the source term based on knowledge of INEL waste-generating processes. Release rate limits for these nuclides (Table 2) were established such that the total dose rate from all nuclides would not exceed a dose of $0.1 \mathrm{mrem} / \mathrm{yr}$, as modeled by the CAP-88 computer code (EPA, 1989a), to the maximally exposed individual (MEI) at the INEL boundary $(12.1 \mathrm{~km})$ (Staley, 1992a). The release limits in Table 2 apply to both LLW and MLLW.

Waste feed stocks may contain limited quantities of gaseous/volatile radionuclides. Carbon-14, iodine-129, and tritium are gaseous nuclides that would not be captured by the offgas treatment system; hence, release rates are assumed to be equal to processing rates for these nuclides. Cesium would volatilize (i.e., become a gas) at incinerator temperatures (boiling point of cesium $=669^{\circ} \mathrm{C}$ ), but would condense in the offgas treatment system as the offgas is cooled to less than $260^{\circ} \mathrm{C}$ prior to HEPA filtration.

The CAP-88 computer code (EPA, 1989a) was used to model dispersion and doses from all exposure pathways as a result of the releases listed in Table 2. Doses are presented in Table 3 for three receptor groups: a) a worker $100 \mathrm{~m}$ from the stack ${ }^{\mathrm{a}}$, b) a hypothetical MEI living at the INEL boundary location where maximum airborne concentrations of incinerator releases would occur (12.1 km south-southwest of WERF), and c) the population living within $80 \mathrm{~km}$ of WERF (based on 1990 census data). The calculated EDE to the $100-\mathrm{m}$ worker is $1.1 \mathrm{mrem} / \mathrm{yr}$, far below the DOE radiation worker limit of $5,000 \mathrm{mrem} / \mathrm{yr}$, and the $500-\mathrm{mrem} / \mathrm{yr}$ limit for nonradiation workers. The EDE to the MEI would be $9.6 \mathrm{E}-02 \mathrm{mrem} / \mathrm{yr}, 100$ times lower than the EPA NESHAP annual limit for the public of $10 \mathrm{mrem} / \mathrm{yr}$. The collective dose to the population within an $80-\mathrm{km}$ radius of WERF $(160,120$ persons) would be 3.7E-01 person-rem/yr EDE, far below doses received from background radiation in southeast Idaho (Section 3.5). Based on a cancer risk factor of 5E-04 deaths/person-rem (NRC, 1991), the increase in cancer incidence in the population from incinerator releases would be 1.9E-04 deaths/yr. This represents a $0.0007 \%$ increase over expected cancer deaths in the $80-\mathrm{km}$ population from all other sources.

a. The minimum distance of $100 \mathrm{~m}$ is frequently used in environmental impact analyses because Gaussian dispersion equations used in most dispersion codes are not intended for nearby dispersion calculations. One hundred meters is considered the minimum distance for which reasonable dispersion estimates can be obtained. 
Table 2. Radionuclide release rate limits from the WERF north stack.

\begin{tabular}{|c|c|c|c|}
\hline Release rate nuclide & $\mathrm{Ci} / \mathrm{yr}$ & $\begin{array}{l}\text { Release rate } \\
\text { nuclide }\end{array}$ & $\mathrm{Ci} / \mathrm{yr}$ \\
\hline $\mathrm{Ag}-110 \mathrm{M}$ & $1.22 \mathrm{E}-01$ & $\mathrm{~Pa}-233$ & $1.26 \mathrm{E}-05$ \\
\hline Am-241 & $1.52 \mathrm{E}-04$ & $\mathrm{~Pa}-233$ & $1.92 \mathrm{E}-06$ \\
\hline $\mathrm{Ba}-137 \mathrm{M}^{\mathrm{a}}$ & 2.95E-01 & $\mathrm{Pa}-234 \mathrm{M}$ & $1.09 \mathrm{E}-03$ \\
\hline $\mathrm{Ba}-140$ & $1.26 \mathrm{E}-02$ & $\mathrm{~Pb}-210$ & $1.26 \mathrm{E}-04$ \\
\hline $\mathrm{Bi}-212$ & $1.26 \mathrm{E}-04$ & $\mathrm{~Pb}-212$ & $1.26 \mathrm{E}-04$ \\
\hline C-14 & $1.26 E-02$ & Po-210 & $1.26 \mathrm{E}-04$ \\
\hline Ce-141 & $1.26 \mathrm{E}-03$ & Pr-144 & 3.57E-03 \\
\hline Ce-144 & 3.57E-03 & $\mathrm{Pu}-238$ & $1.03 \mathrm{E}-03$ \\
\hline $\mathrm{Cm}-244$ & 9.34E-05 & $\mathrm{Pu}-239$ & $3.06 \mathrm{E}-04$ \\
\hline $\mathrm{Co}-57$ & $1.26 \mathrm{E}-03$ & Ra-224 & $1.26 \mathrm{E}-04$ \\
\hline Co-58 & $1.26 \mathrm{E}-03$ & $\mathrm{Rh}-106$ & $1.53 \mathrm{E}-02$ \\
\hline$C 0-60^{2}$ & $7.32 \mathrm{E}-02$ & Ru-103 & $1.26 \mathrm{E}-03$ \\
\hline Cr-51 & $1.26 \mathrm{E}-02$ & $\mathrm{Ru}-106$ & $1.53 \mathrm{E}-02$ \\
\hline Cs-134 & $1.52 E-02$ & Sb-124 & $1.26 \mathrm{E}-03$ \\
\hline $\operatorname{Cs}-137^{\mathrm{a}}$ & 2.95E-01 & Sb-125 & 2.65E-02 \\
\hline Eu-152 & $2.61 E-04$ & Sr-90 & $1.16 \mathrm{E}-02$ \\
\hline Eu-154 & $3.30 \mathrm{E}-04$ & Tc-99 & $1.26 \mathrm{E}-03$ \\
\hline Eu-155 & $1.10 \mathrm{E}-04$ & Th-228 & $1.26 \mathrm{E}-04$ \\
\hline $\mathrm{Fe}-55$ & $1.26 \mathrm{E}-02$ & Th-231 & $9.72 \mathrm{E}-05$ \\
\hline $\mathrm{Fe}-59$ & $1.26 \mathrm{E}-02$ & Th-232 & 8.95E-06 \\
\hline $\mathrm{H}-3$ & $1.26 E+00$ & Th-234 & $1.09 \mathrm{E}-03$ \\
\hline Hf-181 & $1.26 \mathrm{E}-02$ & T1-208 & $1.26 \mathrm{E}-04$ \\
\hline $\mathrm{Hg}-203$ & $1.26 \mathrm{E}-03$ & $\mathrm{U}-234$ & $1.35 \mathrm{E}-03$ \\
\hline I-129 & $1.26 \mathrm{E}-03$ & U-235 & $9.72 \mathrm{E}-05$ \\
\hline Ir-192 & $1.26 \mathrm{E}-03$ & U-238 & $1.09 \mathrm{E}-03$ \\
\hline$K-40$ & $1.26 \mathrm{E}-02$ & $Y-90$ & $1.16 \mathrm{E}-02$ \\
\hline La-140 & $1.26 \mathrm{E}-02$ & $\mathrm{Zn}-65$ & 4.03E-02 \\
\hline Mn-54 & $1.70 \mathrm{E}-03$ & ZR-95 & $1.26 \mathrm{E}-02$ \\
\hline $\mathrm{Nb}-95$ & $1.26 \mathrm{E}-02$ & Total & $2.35 \mathrm{E}+00$ \\
\hline $\mathrm{Ni}-63$ & $1.26 \mathrm{E}-02$ & & \\
\hline Np-237 & $1.26 \mathrm{E}-05$ & & \\
\hline
\end{tabular}

a. Nuclides that contribute greater than $10 \%$ of the total dose.

It should be noted that the release rates in Table 2 and doses in Table 3 represent the maximum limit for WERF and are far greater than those expected from foreseeable incinerator operations. Assuming a nominal efficiency of the WERF offgas treatment system of $99.9 \%$, to reach Table 2 
Table 3. Estimated maximum dose consequences to three receptor groups from LLW and proposed MLLW incineration and LLW compaction and sizing at WERF.

\begin{tabular}{|c|c|c|c|c|c|}
\hline & & Incineration & $\begin{array}{c}\text { Compaction/ } \\
\text { sizing }\end{array}$ & $\begin{array}{c}\text { Annual } \\
\text { total }\end{array}$ & $\begin{array}{c}\text { Project } \\
\text { total }^{\mathrm{a}}\end{array}$ \\
\hline \multicolumn{6}{|c|}{ Worker } \\
\hline & Dose (mrem) & $1.1 E+00$ & $1.0 \mathrm{E}+00$ & $2.1 \mathrm{E}+00$ & $4.2 \mathrm{E}+01$ \\
\hline & Cancer risk $^{\mathrm{b}}$ & 4.4E-07 & $4.0 \mathrm{E}-07$ & $8.4 \mathrm{E}-07$ & $1.7 \mathrm{E}-05$ \\
\hline \multicolumn{6}{|c|}{ MEI } \\
\hline & Dose (mrem) & $9.6 \mathrm{E}-02$ & $6.8 \mathrm{E}-02$ & $1.6 \mathrm{E}-01$ & $3.2 \mathrm{E}+00$ \\
\hline & Cancer risk $^{\mathrm{b}}$ & $4.8 \mathrm{E}-08$ & $3.4 \mathrm{E}-08$ & $8.2 \mathrm{E}-08$ & $1.6 \mathrm{E}-06$ \\
\hline \multicolumn{6}{|c|}{ Population } \\
\hline & $\begin{array}{l}\text { Dose } \\
\text { (person-rem) }\end{array}$ & 3.7E-01 & $2.0 \mathrm{E}-01$ & $5.7 \mathrm{E}-01$ & $1.1 \mathrm{E}+01$ \\
\hline & Cancer risk ${ }^{b, c}$ & $1.9 \mathrm{E}-04$ & $1.0 \mathrm{E}-04$ & $2.9 \mathrm{E}-04$ & $5.8 \mathrm{E}-03$ \\
\hline a. & \multicolumn{5}{|c|}{ Assumes 20-year project life. } \\
\hline b. & \multicolumn{5}{|c|}{$\begin{array}{l}\text { Based on } 4 \mathrm{E}-04 \text { and } 5 \mathrm{E}-04 \text { cancers/person-rem for workers and the public, respectively (NRC, } \\
\text { 1991). }\end{array}$} \\
\hline c. & \multicolumn{5}{|c|}{$\begin{array}{l}\text { Estimated additional number of fatal cancers per year in the affected population of } 160,120 \\
\text { persons (1990 census data). The risk to an individual (increased cancer risk per person) is the } \\
\text { stated risk (total cancers) divided by the population size. For example, the "annual total" risk } \\
\text { (from compaction and sizing releases) of an individual developing fatal cancer equals } 1.8 \mathrm{E}-09 \\
(2.9 \mathrm{E}-04 \div 160,120) \text {, or about } 1 \text { in } 552,000,000 \text {. }\end{array}$} \\
\hline
\end{tabular}

release rates, wastes containing over $1,076 \mathrm{Ci}$ (excluding carbon-14, iodine-129, and tritium, which are assumed to volatize and pass through the filtration system unabated) distributed among Table 2 nuclides would have to be incinerated per year. For perspective, from 1984 to 1991, the WERF incinerator processed wastes containing a total of $17.9 \mathrm{Ci}$ in $9,200 \mathrm{~m}^{3}$ of waste. At a conservative throughput of $4 \mathrm{~m}^{3} / \mathrm{hr}$ for $5,760 \mathrm{hr} / \mathrm{yr}, 23,000 \mathrm{~m}^{3}$ could be incinerated. At radiation levels of past waste, this would equate to only $45 \mathrm{Ci}$ of activity processed per year. Future wastes are expected to be similar to past wastes in composition because wastes will be from the same or similar wastegenerating processes; no new facilities or processes are planned at the INEL that would change the radioactive characteristics of waste received for processing at WERF. Planned environmental restoration and decommissioning and decontaminating activities will generate incinerable waste similar to past processed wastes. 
June 1994

4.1.1.2 Nonradiological Impacts. Nonradiological releases from waste incineration would consist of small fractions of waste constituents and products of combustion, including criteria pollutants.

The WERF incinerator is designed and will be operated to achieve a $99.99 \%$ minimum destruction removal efficiency (DRE) for principal organic hazardous constituents as required under RCRA. The trial burn and emission monitoring programs required by regulations would be conducted to show that WERF emissions would be within RCRA permit requirements. During the trial burn, emissions would be analyzed for $\mathrm{HCl}$, total particulates, oxygen, carbon monoxide, and principal organic hazardous constituents. Carbon monoxide measurements would verify that the incinerator is operating with adequate combustion efficiency.

The WERF incinerator may burn dioxin precursors such as benzene. EPA (1990) has found that dioxins typically form at temperatures above $260^{\circ} \mathrm{C}$, and that dioxin formation is minimized if offgas temperatures are reduced to below $260^{\circ} \mathrm{C}$ before entering air pollution control devices. Dioxin emissions from WERF are not expected to be significant. This is because, when burning dioxin precursors, the incinerator offgas would be cooled to less than $260^{\circ} \mathrm{C}$ before entering the air pollution control equipment.

Releases of criteria pollutants (carbon monoxide, sulfur dioxide $\left(\mathrm{SO}_{2}\right)$, nitrogen oxides $(\mathrm{NO}$ ), and particulates) were evaluated for combined WERF operations (Sterling, 1992). The emission points of criteria pollutants are the north stack, the east stack, and the standby diesel generator exhaust. Table 4 compares estimated annual releases of criteria pollutants with State of Idaho Significant Emission Rates [State of Idaho Division of Environmental Quality (IDEQ), Idaho Administrative Procedures Act (IDAPA) 16.01.01003,86.A]. For proposed, new or modified facilities, emissions exceeding the Idaho Significant Emission Rates require a Prevention of Significant Deterioration Review. Estimated emissions during proposed normal operations of WERF facilities would be well below these emission rates. Calculation of ambient air concentrations and comparison to National Ambient Air Quality Standards were considered for these releases. These standards apply to the total background plus increases in ambient concentrations. Background data are unavailable for criteria pollutants at appropriate public receptor locations. The potential receptor locations are within areas of air quality attainment. The conservatively estimated emissions from WERF would be sufficiently low (i.e., well below the Idaho Significant Emissions Rate) so that WERF emissions would not be expected to lead to nonattainment of National Ambient Air Quality Standards for criteria pollutants.

The lists of hazardous MLLW constituents to be incinerated at WERF were compiled from several sources including analyses of stored wastes, manifest records, and assigned waste codes. Hazardous waste constituents were categorized by chlorinated organic compounds, nonchlorinated organic compounds, and metals. Table 5 presents the most common compounds that are expected to be incinerated at WERF. The RCRA Part A Permit for WERF contains a complete list of compounds that may be treated. 
Table 4. Maximum release rates of criteria pollutants from routine WERF operations.

\begin{tabular}{lcc}
\hline \multicolumn{1}{c}{ Pollutant $^{\mathrm{a}}$} & $\begin{array}{c}\text { WERF } \\
\text { release rate } \\
\text { (ton/yr) }\end{array}$ & $\begin{array}{c}\text { Idaho significant } \\
\text { emissions rate } \\
\text { (ton/yr) }\end{array}$ \\
\hline $\mathrm{CO}^{\mathrm{b}}$ & $1.76 \mathrm{E}+01$ & $1.0 \mathrm{E}+02$ \\
$\mathrm{NO}_{\mathrm{x}}^{\mathrm{c}}$ & $1.25 \mathrm{E}+01$ & $4.0 \mathrm{E}+01$ \\
$\mathrm{SO}_{2}^{\mathrm{d}}$ & $9.73 \mathrm{E}+00$ & $4.0 \mathrm{E}+01$ \\
$\mathrm{PM}^{\mathrm{e}}$ (total) & & $2.5 \mathrm{E}+01$ \\
${\mathrm{PM}-10^{\mathrm{f}}}^{\mathrm{f}}$ & & $1.5 \mathrm{E}+01$ \\
\hline
\end{tabular}

a. Metals included in Table 6 .

b. Carbon monoxide.

c. Nitrogen oxides.

d. Sulfur dioxide.

e. $P M=$ Particulate matter.

f. PM less than 10 micrometers.

The incineration feed rate for chlorinated organic compounds would be governed by the release rate limit for $\mathrm{HCl}$ of $1.8 \mathrm{~kg} / \mathrm{hr}$ ( $40 \mathrm{CFR} 264.343$ ). For simplicity, the maximum feed rate for chlorinated organics is assumed equal to the release limit or $1.8 \mathrm{~kg} / \mathrm{hr}$. Assuming the liquid feed capacity of the incinerator is $50 \mathrm{~kg} / \mathrm{hr}$, it is possible that this limit could be exceeded if sufficiently high concentrations of liquid chlorinated organics were present in the wastes (most of the chlorinated organics are liquids). $\mathrm{HCl}$ emissions would be controlled by blending down concentrations of chlorinated hydrocarbons in liquid waste and/or controlling the feed rate to stay below the $1.8 \mathrm{~kg} / \mathrm{hr}$ $\mathrm{HCl}$ release rate limit. Releases of $1.8 \mathrm{~kg} / \mathrm{hr} \mathrm{HCl}$ would result in a worst-case (under fumigation conditions) airborne concentration at the $100-\mathrm{m}$ worker location of $0.30 \mathrm{mg} / \mathrm{m}^{3}$, well below the threshold limit value (TLV) short-term exposure limit for $\mathrm{HCl} \mathrm{of} 7 \mathrm{mg} / \mathrm{m}^{3}$ (ACGIH, 1991).

Maximum release rates for the nonchlorinated organics listed in Table 5 were used to calculate air concentrations at $100 \mathrm{~m}$ from the stack and at the MEI location to compare to TLVs (ACGIH, 1991). In addition, the IDEQ has established or proposed acceptable ambient concentrations (AACs) for noncarcinogens and acceptable ambient concentrations for carcinogens (AACCs). Note that these 
Table 5. $\mathrm{AACs}^{\mathrm{a}}$ and TLVs (in $\mathrm{mg} / \mathrm{m}^{3}$ ) for representative nonchlorinated and chlorinated organic compounds potentially released during routine mixed waste incineration.

\begin{tabular}{|c|c|c|c|}
\hline Compound non-chlorinated organics & AAC & & $\pi L V^{b}$ \\
\hline 2-Butanone (Methyl Ethyl Ketone) & 5.9 & 590 & \\
\hline Toluene & 3.75 & 147 & \\
\hline Acetone & 17.8 & 1780 & \\
\hline Hexane & 1.8 & 176 & \\
\hline Hexone & 2.05 & 205 & \\
\hline Xylene $(\mathrm{M}, \mathrm{P}, \mathrm{O})$ & 4.384 & 434 & \\
\hline Tributyl Phosphate & 0.025 & 2.2 & \\
\hline Methanol & 2.62 & 262 & \\
\hline Oxalic Acid & 0.01 & 1 & \\
\hline 2-Butoxy Ethanol & 1.21 & 121 & Skin \\
\hline Benzene & $1.2 \mathrm{E}-04^{\mathrm{c}}$ & 32 & Suspected carcinogen \\
\hline Ethylbenzene & 4.384 & 434 & \\
\hline Bis (2-ethylhexyl)-phthalate & $4.2 \mathrm{E}-03^{\mathrm{c}}$ & 10 & \\
\hline Phenol & 0.19 & 19 & Skin \\
\hline Benzo (A) Anthracene & $1.1 \mathrm{E}-06^{\mathrm{C}}$ & 0.2 & Suspected carcinogen \\
\hline Benzo (A) Pyrene & $3.0 \mathrm{E}-07^{\mathrm{c}}$ & 0.2 & $\mathrm{PEL}^{\mathrm{d}}$ suspected carcinogen \\
\hline Benzo (B) Fluoranthene & & 0.2 & Suspected carcinogen \\
\hline Benzo $(G, H, I)$ Perylene & & 0.2 & Suspected carcinogen \\
\hline Diethyl Phthalate & 0.05 & 5 & \\
\hline Fluoranthene & & 0.2 & Suspected carcinogen \\
\hline Fluorine & 0.02 & 1.6 & \\
\hline Napthalene & 0.5 & 52 & \\
\hline \multicolumn{4}{|l|}{ Chlorinated Organics } \\
\hline Methylene Chloride (Dichloromethane) & $2.4 \mathrm{E}-04^{\mathrm{c}}$ & 174 & Suspected carcinogens \\
\hline Tetrachloroethylene & $2.1 \mathrm{E}-03^{\mathrm{c}}$ & 339 & Suspected carcinogens \\
\hline $1,1,1$ Trichloroethane & 19.1 & 1,910 & Suspected carcinogens \\
\hline Trichloroethylene & $7.7 \mathrm{E}-03^{\mathrm{c}}$ & 269 & Suspected carcinogens \\
\hline 1,1,2 Trichloro $-1,2,2$ Trifluoroethane (Freon) & 76.7 & 7670 & \\
\hline 1,1 Dichoroethylene & $2.0 \mathrm{E}-05^{\mathrm{c}}$ & 20 & \\
\hline 1,2 Dichoroethylene & 7.9 & 793 & \\
\hline 1,1 Dichloroethane & $3.8 \mathrm{E}-05^{\mathrm{c}}$ & 810 & (405 NIC ${ }^{e}$ TWA $^{\mathrm{f}}$ value) \\
\hline Chloroform & 4.3E-05 & 49 & Suspected carcinogen \\
\hline
\end{tabular}




\begin{tabular}{|c|c|c|c|}
\hline Compound non-chlorinated organics & AAC & & $T L V^{b}$ \\
\hline Chlorobenzene & 3.5 & 46 & \\
\hline $1,2 \& 1,3 \& 1,4$ & 3.0 & & \\
\hline \multirow[t]{2}{*}{ Dichlorobenzene } & 4.5 & 150 & \\
\hline & & 451 & (60 NIC ${ }^{d} T_{W A} e^{e}$ value) \\
\hline Dichlorodifluoromethane & 49.5 & 4,950 & \\
\hline 1,2,4 Trichlorobenzene & 0.4 & 37 & Ceiling value \\
\hline \multicolumn{4}{|c|}{ a. Limits are acceptable ambient concentrations (AACs). } \\
\hline \multicolumn{4}{|c|}{ b. Short-term exposure limit; otherwise Time-weighted average (ACGIH, 1991), except as noted. } \\
\hline \multicolumn{4}{|c|}{ c. Limit is proposed AACC-Acceptable Ambient Concentration for a Carcinogen. } \\
\hline \multicolumn{4}{|c|}{ d. $\mathrm{PEL}=$ Permissible exposure limit ( $40 \mathrm{CFR} 1910.1000)$} \\
\hline \multicolumn{4}{|c|}{ e. NIC $=$ Notice of intended change in $\mathrm{ACGIH}$ values. } \\
\hline f. TWA = Time-weighted average. & & & \\
\hline
\end{tabular}

IDEQ levels apply to ambient air (i.e., air at locations where the public has access). Therefore, they apply at the MEI location, but not at the $100-\mathrm{m}$ location where the public is not routinely allowed.

The maximum feed rate for each nonchlorinated compound is based on assuming that a full drum of liquid MLLW containing a single organic compound would be fed to the incinerator at a rate of $50 \mathrm{~kg} / \mathrm{hr}$. It was assumed that the incinerator would operate at the required DRE of $99.99 \%$ for organic compounds. The RSAC- 4 computer code ${ }^{b}$ was used to generate short-term atmospheric dispersion factors for both receptors (Staley, 1992b). In accordance with National Oceanic and Atmospheric Administration guidance (Start, 1993), a wind speed of $0.5 \mathrm{~m} / \mathrm{s}$ was used in the code for the $100-\mathrm{m}$ location, and a wind speed of $2.0 \mathrm{~m} / \mathrm{s}$ was used for the MEI location. The code was run using fumigation (worst case) conditions at $100 \mathrm{~m}$, and Stability Class $\mathrm{F}$ (stable atmospheric conditions) for the MEI location. Atmospheric dispersion factors were calculated using Markee sigma values, appropriate for 1-hour or longer releases. Atmospheric dispersion factors used for calculating short-term exposures are $6.0 \mathrm{E}-04$ and $8.4 \mathrm{E}-06 \mathrm{~s} / \mathrm{m}^{3}$ (seconds per cubic meter) for the $100-\mathrm{m}$ and MEI locations, respectively.

For calculating average annual exposures to the MEI, the CAP- 88 computer code was used to generate a dispersion factor, $9.8 \mathrm{E}-08 \mathrm{~s} / \mathrm{m}^{3}$. This code uses 5 -year average, site-specific meteorological data. Further, the emission rate for all contaminants was adjusted to an average annual emission rate; that is, total emissions over the 240 days of WERF operations were averaged over 365 days. Average annual exposures are appropriate for comparison to IDEQ AACs and AACCs and for calculating cancer risks.

b. RSAC-4 is a Gaussian plume dispersion code that has been verified and validated in accordance with the guidelines in ANSI/ANS Standard 10.4-1987 (Wenzel, 1990). 
Because the assumed feed rate, DRE, and applied dispersion factors are identical for all compounds, concentrations would also be identical. The concentration at the $100-\mathrm{m}$ location was calculated to be $8.3 \mathrm{E}-04 \mathrm{mg} / \mathrm{m}^{3}$, and can be compared to TLV short-term exposure limits (STEL), or TLV time-weighted averages (TWA) (Table 5): The calculated concentration is 200 times below the lowest TLV. The maximum hourly average concentration at the MEI location would be $1.2 \mathrm{E}-05 \mathrm{mg} / \mathrm{m}^{3}$, about 16,000 times below the lowest TLV in Table 5. The average annual concentration at the MEI location would be $9.0 \mathrm{E}-08 \mathrm{mg} / \mathrm{m}^{3}, 100,000$ times lower than the lowest IDEQ proposed AAC, and below all proposed AACCs. There would be no health effects to either receptor from such low concentrations.

For metals, feed rate limits (Table 6) were calculated based on RCRA "adjusted Tier I" methodology 0(EPA, 1989d). This is a risk-based approach developed by EPA to limit metals emissions from hazardous waste incinerators to ensure that ambient levels at a public receptor location do not exceed Reference Air Concentrations, which are intended to be protective of human health. For noncarcinogen metals, however, this methodology resulted in very high feed rates (Table 6). For those metals, a more restrictive administrative feed limit of $200 \mathrm{~g} / \mathrm{hr}$ was used.

The incinerator was assumed to process metals at the WERF administrative feed rates presented in Table 6. The baghouse and HEPA filter were each credited with a removal efficiency of $95 \%$ for barium, beryllium, silver, and chromium; $50 \%$ for mercury; and $90 \%$ for the remaining metals. The calculated maximum hourly average concentrations at the 100-m and MEI locations are below all TLVs. Annual average concentrations of metals at the MEI location would be at least 15 times lower than IDEQ proposed AACCs, and at least 100 times lower than proposed AACs.

The NESHAP include limits for beryllium and mercury; however, the limit for beryllium applies to incinerating wastes generated by a "foundry, extraction plant, ceramic plant, or propellant plant." Wastes to be incinerated at WERF do not originate at such facilities; therefore, WERF does not fit the definition of a beryllium waste incinerator. DOE has verified this determination with EPA, Region X (Rothman, 1992). In the case of mercury, NESHAP Subpart E applies to sludge incineration plants and not to hazardous waste incinerators.

Some of the organic compounds and metals to be incinerated at WERF are known or suspected carcinogens. Carcinogenic risks to the MEI (Table 7) were calculated from airborne concentrations of $9.0 \mathrm{E}-08 \mathrm{mg} / \mathrm{m}^{3}$ for nonchlorinated compounds, and Table 6 annual average values for metals at the MEI location. For chlorinated suspected carcinogens, the airborne concentration was determined by applying the appropriate atmospheric dispersion factor $\left(9.0 \mathrm{E}-08 \mathrm{~s} / \mathrm{m}^{3}\right)$ to a release rate calculated from the feed rate limit of $1.8 \mathrm{~kg} / \mathrm{hr}$, and a $99.99 \%$ DRE. The annual average concentration of suspected chlorinated carcinogens at the MEI location was estimated to be $3.2 \mathrm{E}-09 \mathrm{mg} / \mathrm{m}^{3}$. Carcinogenic risks estimate the incremental (above background) probability of an individual developing cancer over a lifetime as a result of exposure to potential carcinogens and are calculated by summing carcinogenic risks due to individual waste constituents (EPA, 1989c). Individual constituent risks are the product of the chronic daily intake of a constituent and the slope factor (EPA, 1989c; 1992). Chronic daily intakes are a function of air concentrations previously presented. Slope factors represent an upper 95th percentile confidence limit of the probability of carcinogenic response based on experimental data used in a linear multistage model (EPA, 1989c). 
Table 6. Calculated concentrations of WERF metals, based on maximum allowable feed rates, compared to TLVs and AACs.

\begin{tabular}{|c|c|c|c|c|c|c|c|}
\hline \multirow[b]{3}{*}{ Metal } & \multicolumn{2}{|c|}{ Feed rates } & \multicolumn{5}{|c|}{ Concentration (mg/m3) } \\
\hline & \multirow[b]{2}{*}{$\begin{array}{l}\text { RCRA } \\
\operatorname{limit}^{a} \\
(\mathrm{~g} / \mathrm{hr})\end{array}$} & \multirow[b]{2}{*}{$\begin{array}{l}\text { WERF } \\
\text { limit } \\
(\mathrm{g} / \mathrm{hr})\end{array}$} & \multicolumn{2}{|c|}{ Annual average } & \multicolumn{2}{|c|}{ Hourly average } & \multirow[b]{2}{*}{ TLV } \\
\hline & & & MEI & $\begin{array}{l}\text { IDEQ } \\
\text { toxics } \\
\text { rules }\end{array}$ & $100 \mathrm{~m}$ & MEI & \\
\hline \multicolumn{3}{|l|}{ Carcinogens } & & AACC & & & \\
\hline Arsenic & $8.4 \mathrm{E}+01$ & $8.4 E+01$ & $1.5 \mathrm{E}-08$ & 2.3E-07 & $1.4 \mathrm{E}-04$ & $2.0 \mathrm{E}-06$ & $\begin{array}{l}0.2, \text { TWA for inorg. } \\
\text { cmpds.; } 0.01 \text { OSHA } \\
\text { PEL }^{\mathrm{b}}\end{array}$ \\
\hline Beryllium & $1.5 \mathrm{E}+02$ & $1.5 \mathrm{E}+02$ & $6.7 \mathrm{E}-09$ & $4.2 \mathrm{E}-06$ & $6.2 \mathrm{E}-05$ & $8.7 \mathrm{E}-07$ & 0.002 TWA \\
\hline Cadmium & $2.0 \mathrm{E}+02$ & $2.0 \mathrm{E}+02$ & $3.6 \mathrm{E}-08$ & $5.6 \mathrm{E}-07$ & $3.3 \mathrm{E}-04$ & 4.7E-06 & $\begin{array}{l}0.05 \text { TWA for respir. Cd; } \\
0.002 \text { NIC }^{c}\end{array}$ \\
\hline Chromium & $3.0 \mathrm{E}+01$ & $3.0 \mathrm{E}+01$ & $1.3 \mathrm{E}-09$ & $8.3 \mathrm{E}-08$ & $1.3 \mathrm{E}-05$ & $1.8 \mathrm{E}-07$ & $\begin{array}{l}0.5 \text { TWA; } 0.05 \text { TWA for } \\
\text { Cr(VI) } \mathrm{H}_{2} \mathrm{O} \text { cmpds }\end{array}$ \\
\hline \multicolumn{3}{|c|}{ Noncarcinogens } & & AAC & & & \\
\hline Antimony & $1.1 \mathrm{E}+04$ & $2.0 E+02^{d}$ & $3.6 \mathrm{E}-08$ & $5.0 \mathrm{E}-03$ & $3.3 \mathrm{E}-04$ & 4.7E-06 & 0.5 TWA \\
\hline Barium & $1.8 \mathrm{E}+06$ & $2.0 E+02^{d}$ & $9.0 \mathrm{E}-09$ & $5.0 \mathrm{E}-03$ & $8.3 E-05$ & $1.2 \mathrm{E}-06$ & 0.5 TWA \\
\hline Lead & $3.2 \mathrm{E}+03$ & $2.0 \mathrm{E}+02^{\mathrm{d}}$ & $3.6 \mathrm{E}-08$ & - & $3.3 \mathrm{E}-04$ & 4.7E-06 & $\begin{array}{l}0.15 \text { TWA for } \mathrm{Pb} \text {, } \\
\text { inorganic dusts/fumes; } \\
0.05 \text { OSHA PEL } \mathrm{PL}^{\mathrm{b}} \text {; } \\
0.01 \text { OSHA PEL } \mathrm{L}^{\mathrm{b}} \text { for } \\
\text { lead arsenate; } 0.05 \text { TWA } \\
\text { for lead chromate }\end{array}$ \\
\hline Mercury & $1.1 E+04$ & $2.0 E+02^{d}$ & $9.0 \mathrm{E}-07$ & $1.0 \mathrm{E}-04$ & $8.4 \mathrm{E}-03$ & $1.2 \mathrm{E}-04$ & 0.05 TWA \\
\hline Silver & $1.1 \mathrm{E}+05$ & $2.0 E+02^{d}$ & $9.0 \mathrm{E}-09$ & $1.0 \mathrm{E}-04$ & $8.3 E-05$ & $1.2 \mathrm{E}-06$ & $\begin{array}{l}0.1 \text { TWA; } 0.01 \text { OSHA } \\
\text { PEL } ; 0.01 \text { TWA for Ag } \\
\text { soluble compounds }\end{array}$ \\
\hline Thallium & $1.1 \mathrm{E}+04$ & $2.0 \mathrm{E}+02^{\mathrm{d}}$ & $3.6 \mathrm{E}-08$ & $1.0 \mathrm{E}-03$ & $3.3 \mathrm{E}-04$ & $4.7 \mathrm{E}-06$ & 0.1 TWA \\
\hline \multicolumn{8}{|c|}{ a. Based on RCRA adjusted Tier I methodology. } \\
\hline \multicolumn{8}{|c|}{ b. PEL = Permissible exposure limit. } \\
\hline \multicolumn{8}{|c|}{ c. NIC = Notice of intended change. } \\
\hline d. WERF a & ministrative & imit (see text & section 4.1 & & - & & \\
\hline
\end{tabular}


June 1994

Table 7. Carcinogenic risk to the MEI from maximum releases of nonradiological carcinogens from the WERF incinerator.

\begin{tabular}{ll}
\multicolumn{1}{c}{ Carcinogen } & $\begin{array}{c}\text { Carcinogenic } \\
\text { risk }\end{array}$ \\
\hline Organics & $7 \mathrm{E}-10$ \\
Benzene & $2 \mathrm{E}-07$ \\
Benzo(a)pyrene & $5 \mathrm{E}-11$ \\
Carbon Tetrachloride & $7 \mathrm{E}-11$ \\
Chloroform & $1 \mathrm{E}-09$ \\
1,1 Dichloroethylene & \\
Metals & $2 \mathrm{E}-07$ \\
Arsenic & $2 \mathrm{E}-08$ \\
Beryllium & $6 \mathrm{E}-08$ \\
Cadmium & $2 \mathrm{E}-08$ \\
Chromium & $5 \mathrm{E}-07$ \\
Annual cancer risk & \\
\hline
\end{tabular}

The annual carcinogenic risk (5E-07) to the MEI from nonradiological releases resulting from proposed MLLW incineration was added to the risk from radiological releases (8.2E-08 from Table 3). This combined annual risk (total Table 3 and Table 7) would be 5E-07, or 5 in 10,000,000. Assuming WERF operates for 20 years, the lifetime increased cancer risk from WERF would be $1 \mathrm{E}-05$ or 1 in 100,000 . For perspective, EPA (1989b) has stated that an increased lifetime cancer risk of 1E-04 (1 in 10,000) is an acceptable level of risk, and it has based standards for exposures to radiation and nonradiological carcinogens on this risk level. By definition, the MEI is subject to a much higher risk than any actual member of the public. Therefore, the cancer risk to the population surrounding WERF would also be below the level determined by EPA to be acceptable.

\subsubsection{Impacts from Compaction and Sizing}

Compaction and sizing operations are performed on LLW only. The sizing room and compactor ventilation air are filtered by two baghouses in series and a HEPA filter which has a combined particulate removal efficiency of $99.99 \%$ using EPA prescribed filtration efficiencies for NESHAP.

An approach similar to that used for deternining incinerator emission impacts was used for compaction and sizing impacts: release limits for known and possible radionuclides were established that would not exceed a dose of $0.1 \mathrm{mrem} / \mathrm{yr}$, as modeled by the CAP- 88 computer code (EPA, 1989a), to the MEI at the INEL boundary. These release rates are summarized in Table 8 . Doses to the MEI, as well as to the $100-\mathrm{m}$ worker and population within $80 \mathrm{~km}$ of WERF resulting from 
Table 8. Estimated radionuclide release rate limits from the WERF east stack.

\begin{tabular}{|c|c|c|c|}
\hline \multicolumn{2}{|c|}{ Release rate } & \multicolumn{2}{|c|}{ Release rate } \\
\hline Nuclide & $(\mathrm{Ci} / \mathrm{y})$ & Nuclide & $(\mathrm{Ci} / \mathrm{y})$ \\
\hline $\mathrm{Ag}-110 \mathrm{M}^{\mathrm{a}}$ & $1.09 \mathrm{E}-01$ & $\mathrm{~Pa}-234$ & $1.91 \mathrm{E}-06$ \\
\hline Am-241 & $1.51 \mathrm{E}-04$ & $\mathrm{~Pa}-234 \mathrm{M}$ & $1.08 \mathrm{E}-03$ \\
\hline $\mathrm{Ba}-137 \mathrm{M}$ & $3.97 \mathrm{E}-02$ & $\mathrm{~Pa}-233$ & 2.83E-05 \\
\hline $\mathrm{Ba}-140$ & $2.83 \mathrm{E}-03$ & $\mathrm{~Pb}-210$ & $2.83 \mathrm{E}-04$ \\
\hline $\mathrm{Bi}-212$ & $2.83 \mathrm{E}-04$ & $\mathrm{~Pb}-212$ & $2.83 \mathrm{E}-04$ \\
\hline C-14 & 2.83E-03 & Po-210 & 2.83E-04 \\
\hline Ce-141 & 2.83E-03 & Pr-144 & $3.58 \mathrm{E}-03$ \\
\hline Ce-144 & $3.58 \mathrm{E}-03$ & $\mathrm{Pu}-238^{\mathrm{a}}$ & $1.02 \mathrm{E}-03$ \\
\hline $\mathrm{Cm}-244$ & $9.28 \mathrm{E}-05$ & Pu-239 & $3.04 \mathrm{E}-04$ \\
\hline Co-57 & 2.83E-03 & $\mathrm{Ra}-224$ & 2.83E-04 \\
\hline Co-58 & $2.83 \mathrm{E}-03$ & Rh-106 & $1.54 \mathrm{E}-02$ \\
\hline Co- $60^{a}$ & 7.04E-02 & Ru-103 & 2.83E-03 \\
\hline Cr-51 & $2.83 \mathrm{E}-03$ & Ru-106 & $1.54 \mathrm{E}-02$ \\
\hline Cs-134 & $1.01 \mathrm{E}-02$ & Sb-124 & $2.83 \mathrm{E}-03$ \\
\hline Cs-137 & 3.97E-02 & $\mathrm{Sb}-125$ & $2.66 \mathrm{E}-02$ \\
\hline Eu-152 & 2.62E-04 & Sr-90 & $2.04 \mathrm{E}-03$ \\
\hline Eu-154 & 3.31E-04 & Tc-99 & 2.83E-03 \\
\hline Eu-155 & $1.10 \mathrm{E}-04$ & Th-228 & $2.83 \mathrm{E}-04$ \\
\hline $\mathrm{Fe}-55$ & 2.83E-03 & Th-231 & $9.66 \mathrm{E}-05$ \\
\hline $\mathrm{Fe}-59$ & 2.83E-03 & Th-232 & $8.90 \mathrm{E}-06$ \\
\hline $\mathrm{H}-3$ & $2.83 E+00$ & Th-234 & $1.08 \mathrm{E}-03$ \\
\hline Hf-181 & $2.83 \mathrm{E}-03$ & T1-208 & 2.83E-04 \\
\hline $\mathrm{Hg}-203$ & $2.83 \mathrm{E}-03$ & U-234 & $1.34 \mathrm{E}-03$ \\
\hline I-129 & $2.83 \mathrm{E}-03$ & U-235 & $9.66 \mathrm{E}-05$ \\
\hline Ir-192 & 2.83E- 03 & U-238 & $1.08 \mathrm{E}-03$ \\
\hline $\mathrm{K}-40$ & $2.83 \mathrm{E}-03$ & Y-90 & $2.04 \mathrm{E}-03$ \\
\hline La-140 & 2.83E- 03 & $\mathrm{Zn}-65$ & $1.62 \mathrm{E}-02$ \\
\hline $\mathrm{Mn}-54$ & $1.71 E-03$ & Zr-95 & $2.83 \mathrm{E}-03$ \\
\hline $\mathrm{Nb}-95$ & 2.83E-03 & & \\
\hline $\mathrm{Ni}-63$ & 2.83E-03 & TOTAL & $3.25 \mathrm{E}+00$ \\
\hline Np-237 & 2.83E-05 & & \\
\hline
\end{tabular}


Table 8 releases, are summarized in Table 3. All doses would be well below DOE and EPA guidelines for worker and public exposures.

Using the assumed radioactive particulate resuspension rate of $1 \%$ (Elder et al., 1986) and the rated removal efficiency of $99.99 \%$, wastes containing over $100,000 \mathrm{Ci}$ of nuclides would have to be processed annually through compaction and sizing operations to reach Table 8 release rates. Future wastes are expected to be similar to past wastes, and there are no foreseeable circumstances that could result in processing wastes with this high level of radionuclides. To illustrate, all past compactor operations have processed approximately $3,500 \mathrm{~m}^{3}$ of uncompacted LLW, containing only $25.7 \mathrm{Ci}$ of radioactivity. The predicted future compaction rate is approximately $1,200 \mathrm{~m}^{3} / \mathrm{yr}$ but could range up to $2,000 \mathrm{~m}^{3} / \mathrm{yr}$, equivalent to approximately $15 \mathrm{Ci}$ of radioactivity per year (at past activity levels). Past sizing operations have processed approximately $4,700 \mathrm{~m}^{3}$ of metal, with a total activity of $1.4 \mathrm{Ci}$. Future sizing rates are predicted to be approximately $420 \mathrm{~m}^{3} / \mathrm{yr}$, but past experience has shown this rate could range up to $880 \mathrm{~m}^{3} / \mathrm{yr}$, equivalent to $0.26 \mathrm{Ci}$ (at past activity levels).

\subsubsection{Cumulative Impacts}

In considering cumulative impacts, DOE reviewed all known and reasonably foreseeable emission sources at INEL. The cumulative radiation dose equivalent from all atmospheric releases from the entire INEL is reported annually in environmental reports (e.g., DOE, 1991b,c). In addition to those reported doses, various major planned activities on the INEL would add to the cumulative dose. Planned activities are shown in Table 9. The listed doses are considered to be small. Other sources (e.g., Test Reactor Area and Naval Reactor Facility) are included in the "present INEL" dose. Activities at Test Area North (TAN) in the northern part of INEL are not considered in this analysis (except as part of the INEL total for existing activities). Doses from TAN are not additive because of the distance from WERF (approximately $35 \mathrm{~km}$ ) and the different MEI location for TAN releases.

Operation of WERF at the maximum release rates in Tables 2 and 8 could result in maximum added EDE to the MEI of $0.16 \mathrm{mrem} / \mathrm{yr}$. However, as explained in Sections 4.1.1.1 and 4.1.2, releases and resulting doses are expected to be far below those presented here. Also, it should be noted that the MEI locations are different for each INEL facility, so doses are not additive. Doses presented in Table 9 from cumulative INEL emissions are considered to be low.

Normal operations (incineration, solidification, sizing, and compaction) at WERF are estimated to result in 2.9E-04 additional latent cancer fatalities per year from radiological emissions to the affected population of 160,120 persons (1990 census data). This is equal to $1.8 \mathrm{E}-09$ fatal cancers per person. The increased risk of an individual developing fatal cancer as a result of WERF emissions would be approximately 1 in 552,000,000. In this same population, an average 18.6 cancer deaths occur each year, based on 1983 EPA/National Cancer Institute (NCI) data from eastern Idaho (EPA and NCI, 1983). Therefore, activities at WERF would cause a $0.0016 \%$ statistical increase in cancer deaths and would not be a significant contributor to, nor discernable in, the normal cancer fatality rate in the surrounding population. 
Table 9. Estimated cumulative radiological doses from existing INEL activities, proposed RWMC remedial activities, and WERF operations.

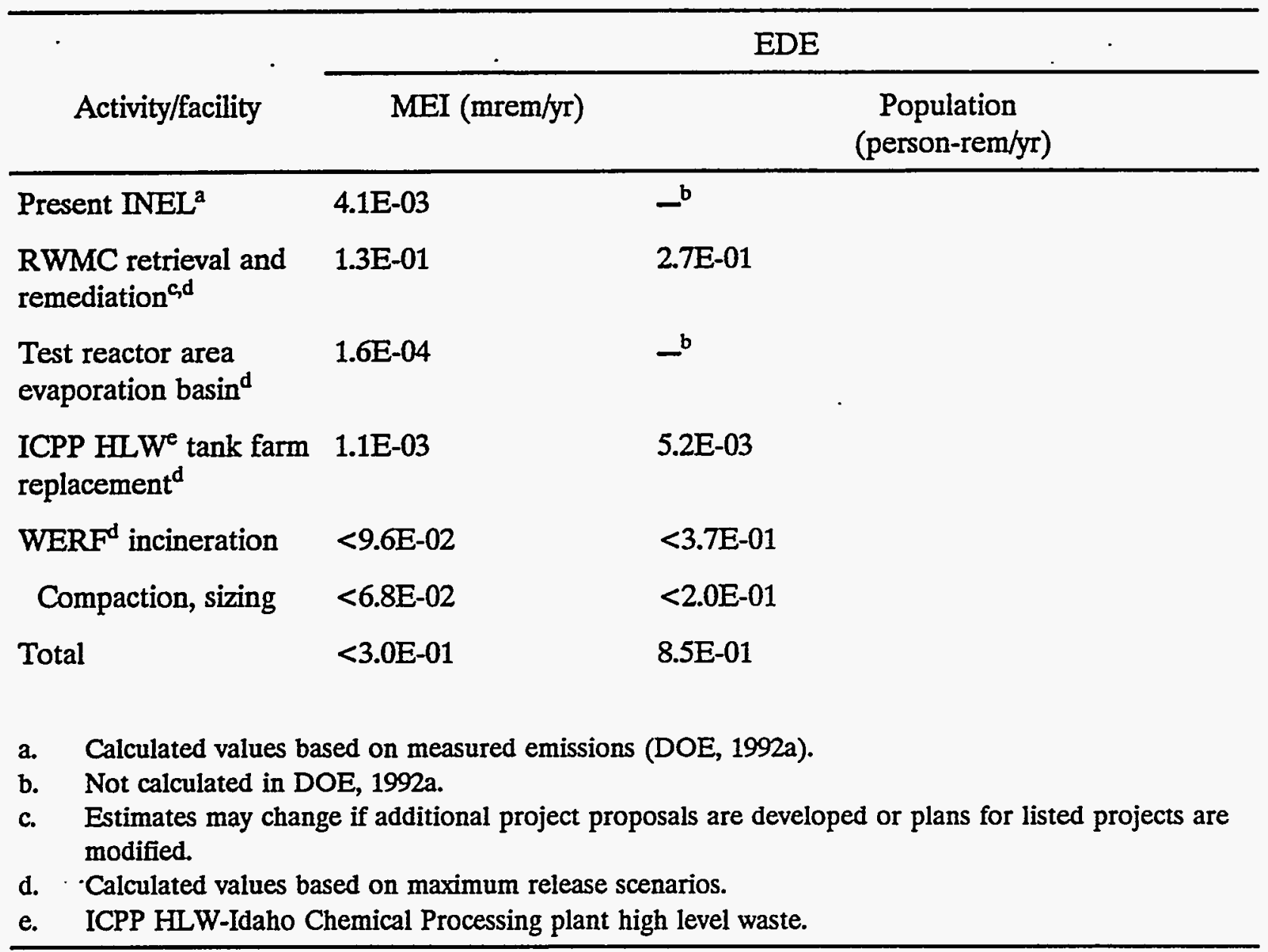

WERF would add an insignificant increment to INEL $\mathrm{NO}_{x}$ and $\mathrm{SO}_{2}$ emissions. In 1990, INEL operations emitted approximately 173 tons of $\mathrm{NO}_{x}$ and 134 tons of $\mathrm{SO}_{2}$ (DOE, 1991b); the maximum estimated WERF contribution to these emissions was 12.5 and 9.7 tons, respectively.

LLW transportation activities associated with WERF operations are estimated to result in a $0.000034 \%$ to $0.000091 \%$ statistical increase in cancer deaths. This would not be a significant contributor to, nor discernable in, the normal cancer fatality rate.

\subsection{Impacts of Transportation of LLW to and from INEL}

Preparation and transportation of LLW for offsite processing would be performed in accordance with applicable sections of 10 CFR and 49 CFR 170-179. Radiation levels on the outer trailer surface would not exceed $200 \mathrm{mrem} / \mathrm{hr}$ on contact or $10 \mathrm{mrem} / \mathrm{hr}$ at $2 \mathrm{~m}$; levels "at any normally occupied position" in the vehicle would not exceed $2 \mathrm{mrem} / \mathrm{hr}$. These maximum allowable levels are assumed for this analysis. Known treatment facilities capable of processing INEL LLW are all within 3,200 km 
of INEL. However, $3,750 \mathrm{~km}$ was conservatively assumed for calculating impacts of LLW transportation to bound the onsite transportation and possible routing alternatives.

The number of trips to and from the commercial facility was estimated based on the volume, density, and volume reduction factors of LLW. The number of trips was expressed as a range (Table 10) because of the dependence on the volume and mass (weight) capacity of the transportation trailer. Estimates are provided for "Year 1", when shipment of INEL's current LLW inventory would occur, and "Years 2 through 20," when routine annual shipments would occur. The estimated rate of INEL LLW shipments is small compared to the annual average of 2 million nonDOE radioactive shipments per year. Many of these non-DOE shipments, however, are small quantities such as United Parcel Service parcels (Wolfe, 1984).

Transportation of LLW from INEL to a commercial processor may result in radiological exposures to truck drivers and the public along the route (radiological-nonoccupational) (Table 10). In addition to the incident-free or normal occurrences, a mishap or accident could occur in route. The health effects from normal and accidental occurrences have been assessed based on effect per $\mathrm{km}$ transported (Rao et al., 1981; Wolfe, 1984). Radiological effects are expressed in person-rem per $\mathrm{km}$ and nonradiological effects as consequences per $\mathrm{km}$. A consequence is a deleterious health effect, which results in death after a period of time. The last column of Table 10 and footnote $\mathrm{g}$ summarize all effects in terms of deaths per year and deaths over the projected 20-year campaign.

Table 10 shows that the potential impacts of the proposed LLW shipments to and from a commercial processing facility would be extremely small. The maximum cumulative radiological health risk to transportation workers from incident-free waste shipping over the 20-year campaign is estimated to be 0.09 deaths. The maximum radiological and nonradiological health risk to the public from incident-free waste shipping over 20 years is estimated to be 0.82 deaths. Up to 0.77 deaths may also occur from transportation accidents. It should be noted, however, that the analysis presented here is considered conservative; actual effects would likely be less. For perspective, in the same population about 3,000 deaths from cancer from all other sources would be expected over the 20-year shipping campaign. Other studies that have reported the impacts from transportation of radioactive materials have also concluded that the health effects are minimal (NRC, 1977; DOE, 1980).

Only limited quantities ( $<5 \mathrm{~m}^{3} / \mathrm{yr}$ ) of non-INEL MLLW would be shipped to INEL. It is conceivable that these wastes could be shipped in as small an increment as 1 drum per shipment. One drum is equal to approximately $0.2 \mathrm{~m}^{3}$; therefore, up to 25 shipments may occur to reach the $5 \mathrm{~m}^{3} / y \mathrm{r}$ limited quantity. Because these shipments would involve very small quantities of MLLW, it is assumed that per $\mathrm{km}$ impacts from shipping MLLW would be bounded by per km impacts from transporting trailers filled with LLW; for conservatism, this analysis assumes equal per $\mathrm{km}$ impacts. It is also assumed the maximum trip distance is $3,750 \mathrm{~km}$, for MLLW. From these assumptions, the annual number of radiological, nonoccupational, incident-free cancer deaths expected from 25 shipments of MLLW would be $25 \times 3,750 \mathrm{~km}$ x $2 \mathrm{E}-04$ person-rem $/ \mathrm{km} \times 5 \mathrm{E}-04$ cancers/person rem $=9.4 \mathrm{E}-03$, representing a $0.0000017 \%$ increase over cancer deaths normally expected in the affected populations. 
Table 10. Summary of health effects from transportation of LLW., ${ }^{a, b} c$

\begin{tabular}{|c|c|c|c|c|c|c|c|c|}
\hline \multicolumn{2}{|c|}{ Type of effect } & $\begin{array}{l}\text { Unit dose or } \\
\text { consequence }\end{array}$ & Effect per trip ${ }^{d}$ & $\begin{array}{l}\text { Cancer } \\
\text { deaths per } \\
\text { trip }^{\text {e }}\end{array}$ & Type of $L L W^{f}$ & Effect per year & Deaths/year & \\
\hline \multicolumn{9}{|l|}{ Year 1} \\
\hline \multirow{3}{*}{$\begin{array}{l}\text { Radiological- } \\
\text { occupational }\end{array}$} & \multirow[t]{3}{*}{ Incident-free } & \multirow{3}{*}{$\begin{array}{l}\text { 3E-5 person-rem per } \\
\mathrm{km}\end{array}$} & \multirow[t]{3}{*}{ 1.1E-1 person-rem } & \multirow[t]{3}{*}{ 4.5E-05 } & Incinerable (87-96) & 9.6-10.6 person-rem & $0.00392-0.00432$ & \\
\hline & & & & & Compactable (41-46) & 4.5-5.1 person-rem & $0.00185-0.00207$ & \\
\hline & & & & & Sizable (51-57) & 5.6-6.3 person-rem & $0.00230-0.00257$ & \\
\hline \multirow{6}{*}{$\begin{array}{l}\text { Radiological-non- } \\
\text { occupational } f\end{array}$} & \multirow[t]{3}{*}{ Incident-free } & \multirow{3}{*}{$\begin{array}{l}\text { 2E-4 person-rem per } \\
\mathrm{km}\end{array}$} & \multirow{3}{*}{$\begin{array}{l}\text { 7.5E-01 person- } \\
\text { rem }\end{array}$} & \multirow[t]{3}{*}{$3.8 \mathrm{E}-4$} & Incinerable (87-96) & 65.3-72.0 person-rem & $0.0331-0.0365$ & \\
\hline & & & & & Compactable (41-46) & 30.8-34.5 person-rem & $0.0156-0.0175$ & \\
\hline & & & & & Sizable (51-57) & 38.3-42.8 person-rem & $0.0194-0.0217$ & \\
\hline & \multirow[t]{3}{*}{ Accident } & \multirow{3}{*}{$\begin{array}{l}\text { 7E-6 person-rem per } \\
\mathrm{km}\end{array}$} & \multirow{3}{*}{$\begin{array}{l}2.6 \mathrm{E}-02 \text { person- } \\
\text { rem }\end{array}$} & \multirow[t]{3}{*}{$1.3 \mathrm{E}-5$} & Incinerable $(87-96)$ & 2.3-2.5 person-rem & $0.00113-0.00125$ & \\
\hline & & & & & Compactable (41-46) & 1.1-1.2 person-rem & $0.000533-0.000598$ & \\
\hline & & & & & Sizable (51-57) & 1.3-1.5 person-rem & $0.000663-0.000741$ & \\
\hline \multirow[t]{6}{*}{ Non-radiological } & \multirow[t]{3}{*}{ Incident-free } & \multirow[t]{3}{*}{$\begin{array}{l}5 \mathrm{E}-9 \text { consequence per } \\
\mathrm{km}\end{array}$} & \multirow[t]{3}{*}{$\begin{array}{l}1.9 \mathrm{E}-5 \\
\text { consequence }\end{array}$} & & Incinerable (172-190) & $\begin{array}{l}0.00327-0.00361 \\
\text { consequence }\end{array}$ & $0.00327-0.00361$ & \\
\hline & & & & & Compactable (68-76) & $\begin{array}{l}0.00129-0.00144 \\
\text { consequence }\end{array}$ & $0.00129-0.00144$ & \\
\hline & & & & & Sizable (84-94) & $\begin{array}{l}0.00160-0.00180 \\
\text { consequence }\end{array}$ & $0.00160-0.00180$ & \\
\hline & \multirow[t]{3}{*}{ Accident } & \multirow[t]{3}{*}{$3 \mathrm{E}-8$ deaths per $\mathrm{km}$} & \multirow{3}{*}{\multicolumn{2}{|c|}{ 1.1E-4 deaths }} & Incinerable (172-190) & $0.0189-0.0209$ deaths & $0.0189-0.0209$ & \\
\hline & & & & & Compactable (68-76) & $0.00748-0.00836$ deaths & $0.00748-0.00836$ & \\
\hline & & & & & Sizable (84-94) & $0.00924-0.0103$ deaths & $0.00924-0.0103$ & \\
\hline \multicolumn{9}{|l|}{ Years 2-20 } \\
\hline \multirow{3}{*}{$\begin{array}{l}\text { Radiological- } \\
\text { occupational }\end{array}$} & \multirow[t]{3}{*}{ Incident-free } & \multirow{3}{*}{$\begin{array}{l}\text { 3E-5 person-rem per } \\
\mathrm{km}\end{array}$} & \multirow[t]{3}{*}{ 1.1E-1 person-rem } & \multirow[t]{3}{*}{$4.5 \mathrm{E}-5$} & Incinerable (35-39) & 3.9-4.3 person-rem & $0.00158-0.00176$ & \\
\hline & & & & & Compactable (28-32) & 3.1-3.5 person-rem & $0.00126-0.00144$ & \\
\hline & & & & & Sizable (22-24) & 2.4-2.6 person-rem & $0.000990-0.00108$ & \\
\hline \multirow{6}{*}{$\begin{array}{l}\text { Radiological-non- } \\
\text { occupational }^{\mathrm{f}}\end{array}$} & Incident-free & 2E-4 person-rem per & 7.5E-1 person-rem & $3.8 \mathrm{E}-4$ & Incinerable (35-39) & 26.3-29.3 person-rem & $0.0133 \cdot 0.0148$ & \\
\hline & & $\mathrm{km}$ & & & Compactable (28-32) & 21.0-24.0 person-rem & $0.0106-0.0122$ & \\
\hline & & & & & Sizable (22-24) & 16.5-18.0 person-rem & $0.00836-0.00912$ & \\
\hline & Accidental & 7E-6 person-rem per & 2.6E-2 person-rem & $1.3 \mathrm{E}-5$ & Incinerable (35-39) & 0.9-1.0 person-rem & $0.000455-0.000507$ & \\
\hline & & $\mathrm{km}$ & & & Compactable (28-32) & $0.7-0.8$ person-rem & $0.000364-0.000416$ & \\
\hline & & & & & Sizable $(22-24)$ & $0.6-0.7$ person-rem & $0.000286-0.000312$ & \\
\hline Non-radiological & Incident-free & $\begin{array}{l}\text { 5E-9 consequences per } \\
\mathrm{km}\end{array}$ & $\begin{array}{l}1.9 \mathrm{E}-5 \\
\text { consequence }\end{array}$ & & Incinerable (58-64) & $\begin{array}{l}0.00110-0.00122 \\
\text { consequence }\end{array}$ & $0.00110-0.00122$ & \\
\hline & & & & & Compactablè (46-52) & $\begin{array}{l}0.000874-0.000988 \\
\text { consequence }\end{array}$ & $0.000874-0.000988$ & 点 \\
\hline & & & & & Sizable $(36-40)$ & $\begin{array}{l}0.000684-0.000760 \\
\text { consequence }\end{array}$ & $0.000684-0.000760$ & 8 \\
\hline
\end{tabular}


Table 10. (continued).

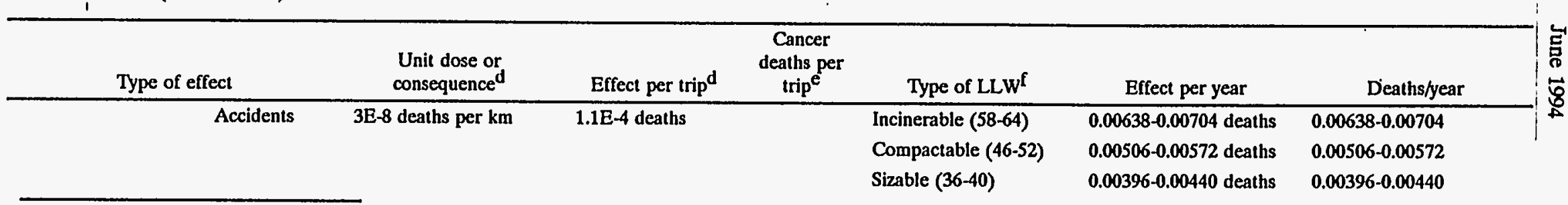

a. Travel distance is assumed to be $3,750 \mathrm{~km}$.

b. Travel demographics are assumed to be $90 \%$ rural $\left(6\right.$ person $\left./ \mathrm{km}^{2}\right), 5 \%$ urban $\left(719\right.$ person $\left./ \mathrm{km}^{2}\right)$, and $5 \%$ suburban $\left(3861\right.$ person $\left./ \mathrm{km}^{2}\right)$.

c. The maximum cumulative radiological health risk to transportation workers from incident-free waste shipping over the 20 -year campaign is estimated to be 0.09 deaths. The maximum radiological and nonradiological health risk to the public from incident-free waste shipping over 20 years is estimated to be 0.82 deaths. Up to 0.77 deaths may also occur from transportation accidents.

d. 'Consequences' are health effects that result in death after some latency period.

e. Assumes $4 \mathrm{E}-04$ and $5 \mathrm{E}-4$ cancer deaths per person-rem, for workers and public, respectively.

f. Number of shipments per designated year. 
Transportation impacts from the hazardous (nonradioactive) component of MLLW would result only if an accident involving a spill were to occur. National statistics for accidents involving spills of hazardous materials show a rate of 0.28 accidents per million vehicle miles traveled (US Bureau of Land Management, 1990). This statistic includes tanker trucks, which are extremely vulnerable to spilling in an accident. At the above conservative distances, number of shipments, and accident rate, about 0.02 accidents per year, or one accident in 50 years, would be expected involving MLLW shipments to INEL. This low frequency, considered along with the very low quantities assumed (one drum per shipment) and U.S. Department of Transportation packaging requirements for hazardous wastes, makes the likelihood of injuries from hazardous materials releases in an accident very low.

The potential impacts of transporting LLW and MLLW across the Fort Hall Indian Reservation, south of INEL, were considered. For conservatism, it is assumed that all LLW is shipped from INEL through Pocatello, and south across $17 \mathrm{~km}$ of the reservation, and that 24 of the 25 annual shipments of MLLW are shipped from the west, through Pocatello to INEL, across $35 \mathrm{~km}$ of the reservation (the remaining MLLW shipment is assumed to originate in Idaho Falls, and would not cross reservation land). If the same per $\mathrm{km}$ effects presented in Table 10 are assumed, the consequences to the Fort Hall population are calculated by multiplying effects in Table 10 by the ratio of the distances: $17 \mathrm{~km} / 3,750 \mathrm{~km}$ for LLW and $35 \mathrm{~km} / 3,750 \mathrm{~km}$ for MLLW. For example, the annual number of radiological, nonoccupational, incident-free cancer deaths expected in the Fort Hall population from 199 shipments of LLW across the reservation would be 3E-04. This represents about a 5E-10, or 1 in 2 billion increased risk over all other sources of cancer. Nonoccupational deaths from accidents from the 199 shipments would be $1.0 \mathrm{E}-04$, or about 1 death in 10,000 years.

\subsection{Potential Impacts from Accidents}

Four accidents were evaluated involving different areas of WERF and different waste forms. These accidents were an earthquake, a baghouse/HEPA filter fire, an ash spill, and a compactor fire. The accidents were selected from numerous scenarios considering natural phenomena, external events, operational systems, safety features, and support systems. The accident analyses are based on conservative assumptions, which tend to overestimate the actual environmental impacts. Examples of such assumptions include: maximum inventories/throughput rates, conservative meteorological conditions, and that receptors would remain in the worst exposure locations through the duration of accidental releases. The assumptions provide assurance that an upper bound has been identified for the magnitude of potential environmental impact. The accidents and consequences are briefly summarized below; greater detail is provided in Schofield (1992a, b, c, and d).

For accidents with releases to the outside air, the RSAC- 4 computer code was used to calculate doses to the $100-\mathrm{m}$, worker and MEI, and to generate atmospheric dispersion factors for calculating airborne concentrations at those locations from nonradiological, hazardous releases. 


\subsubsection{Earthquake}

The bounding, credible accident is one in which an earthquake occurs toward the end of a 10day (240-hr) incineration campaign, causing the incinerator room roof to slip off its supports and fall. The probability of occurrence is estimated to be $8.5 \mathrm{E}-05$. As the roof collapsed, it would sever the offgas lines connected to the incinerator, allowing the offgas and resuspended bottom ash containing radionuclides and hazardous metals to escape unabated to the environment. The release would continue over a period of 8 hours.

For the earthquake scenario, radionuclides and heavy metals would be released at ground level to the surrounding environment, exposing workers in the immediate vicinity of the incinerator building (who would evacuate the area within 10 minutes), as well as downwind receptors. No impact from organics releases would be expected from this accident because volatile organic compounds would have been destroyed in the incinerator prior to release.

At the maximum processing rate, there could be up to $38 \mathrm{Ci}$ of radioactivity distributed among Table 2 nuclides in the accumulated ash (except for carbon-14, hydrogen-3, and iodine-129, which volatilize and are not present in ash). A total of $0.38 \mathrm{Ci}$ could be released from this accident. As calculated by the RSAC-4 code, this release would result in an 8-hour dose to a nearby worker/visitor of $1.3 \mathrm{rem}$ and to the $100-\mathrm{m}$ worker of $990 \mathrm{mrem}$. A maximum of 12 operations and support workers would be located within the operating areas where these exposures might occur. These doses overestimate what might realistically occur because workers would don protective equipment, be evacuated from the area, and would be exposed for only a fraction of the 8-hour duration of the release. The dose to the MEI, who is assumed to be exposed for 8 hours, would be 2.7 mrem. No health effects would be anticipated from these doses.

For metals, WERF administrative maximum feed rates, as specified in Table 6, are assumed. Other assumptions are the same as for radionuclides. Table 11 presents calculated concentrations at the nearest worker, $100-\mathrm{m}$, and MEI locations. Concentrations of all metals would be less than IDLH limits at both worker locations. Acute metal exposure to nearby workers exceeding TLV values may produce symptoms such as irritation of the respiratory tract, redness and swelling of the mouth and gums, sweating, thirst, metallic taste, headache, digestive disorders and muscle pain. Exposures below IDLH values would not incapacitate workers such that they would be unable to evacuate or don protective equipment. Concentrations at the MEI location would be less than TLVs.

\subsubsection{Baghouse/HEPA Filter Fire}

In this accident scenario, a fire starts in the baghouse of the north stack filtration system during maintenance while the incinerator is shut down. The probability of occurrence is estimated to be 2.7E-04/yr. The halon fire suppression system is assumed to fail and the fire spreads to the HEPA filters. The high temperatures cause the housing seals to fail on both the baghouse and HEPA filters, releasing radioactive and hazardous metal particulates into the highbay of the incinerator building and out an open door. The fire/release continues for 1 hour. 
Table 11. Estimated metal concentrations resulting from the earthquake accident.

\begin{tabular}{lccccc}
\hline Metal & $\begin{array}{c}\text { Worker } \\
\left(\mathrm{mg} / \mathrm{m}^{3}\right)\end{array}$ & $\begin{array}{c}100-\mathrm{m} \\
\text { concentration } \\
\left(\mathrm{mg} / \mathrm{m}^{3}\right)\end{array}$ & $\begin{array}{c}12.1 \mathrm{~km} \\
\left(\mathrm{mg} / \mathrm{m}^{3}\right)\end{array}$ & $\begin{array}{c}\text { NSB } \\
\text { Concentratio } \\
\mathrm{n}\left(\mathrm{mg} / \mathrm{m}^{3}\right)\end{array}$ & $\begin{array}{c}\text { TLV/PEL } \\
\left(\mathrm{mg} / \mathrm{m}^{3}\right)\end{array}$ \\
\hline Arsenic & $3.6 \mathrm{E}+00$ & $5.0 \mathrm{E}-02$ & $1.00 \mathrm{E}+02$ & $4.9 \mathrm{E}-05$ & $1.0 \mathrm{E}-02^{\mathrm{d}}$ \\
Beryllium & $6.4 \mathrm{E}+00$ & $9.0 \mathrm{E}-02$ & $1.00 \mathrm{E}+01$ & $8.7 \mathrm{E}-05$ & $2.0 \mathrm{E}-03^{\mathrm{e}}$ \\
Cadmium & $8.5 \mathrm{E}+00$ & $1.2 \mathrm{E}-01$ & $5.00 \mathrm{E}+01$ & $1.2 \mathrm{E}-04$ & $1.0 \mathrm{E}-02^{\mathrm{e}}$ \\
Chromium & $1.3 \mathrm{E}+00$ & $1.8 \mathrm{E}-02$ & $-{ }^{\mathrm{c}}$ & $1.7 \mathrm{E}-05$ & $5.0 \mathrm{E}-02^{\mathrm{e}}$ \\
Antimony & $8.5 \mathrm{E}+00$ & $1.2 \mathrm{E}-01$ & $8.00 \mathrm{E}+01$ & $1.2 \mathrm{E}-04$ & $5.0 \mathrm{E}-01^{\mathrm{e}}$ \\
Barium & $8.5 \mathrm{E}+00$ & $1.2 \mathrm{E}-01$ & $1.10 \mathrm{E}+03$ & $1.2 \mathrm{E}-04$ & $5.0 \mathrm{E}-01^{\mathrm{e}}$ \\
Lead & $8.5 \mathrm{E}+00$ & $1.2 \mathrm{E}-01$ & $7.00 \mathrm{E}+02$ & $1.2 \mathrm{E}-04$ & $5.0 \mathrm{E}-02^{\mathrm{d}}$ \\
Mercury & $8.5 \mathrm{E}+00$ & $1.2 \mathrm{E}-01$ & $2.80 \mathrm{E}+01$ & $1.2 \mathrm{E}-04$ & $3.0 \mathrm{E}-02^{\mathrm{f}}$ \\
Silver & $8.5 \mathrm{E}+00$ & $1.2 \mathrm{E}-01$ & $-\mathbf{C}^{\mathrm{c}}$ & $1.2 \mathrm{E}-04$ & $1.0 \mathrm{E}-02^{\mathrm{e}}$ \\
Thallium & $8.5 \mathrm{E}+00$ & $1.2 \mathrm{E}-01$ & $2.00 \mathrm{E}+01$ & $1.2 \mathrm{E}-04$ & $1.0 \mathrm{E}-01^{\mathrm{e}}$
\end{tabular}

a. NIOSH, 1990.

b. NSB - nearest site boundary.

c. No IDLH value exists for this metal.

d. OSHA PEL (29 CFR 1910.1000).

e. TWA (ACGIH, 1991).

f. STEL (ACGIH, 1991).

Estimated radiological releases from this event are based on the maximum processing rate distributed among Table 2 nuclides. Fifteen percent of the ash is fly ash; 90\% of the fly ash is retained in the baghouse, and the remaining $10 \%$ is trapped on the HEPA filters with $99.97 \%$ efficiency. The calculated release from this accident is $2.7 \mathrm{E}-02 \mathrm{Ci}$ of radioactivity distributed among Table 2 nuclides in the accumulated ash (except for carbon-14, hydrogen-3, and iodine-129, which volatilize and are not present in ash). The worker inside the incinerator building is assumed to be exposed for 10 minutes before evacuating the area; the dose to this worker was calculated to be 2.7E-01 rem, or 270 mrem EDE. A worker $100 \mathrm{~m}$ downwind from the release is assumed to be exposed for the entire hour of the release; the dose to this individual would be $7.0 \mathrm{E}-02 \mathrm{rem}$, or 70 mrem. The MEI is assumed to be exposed for 1 hour, resulting in a dose of 2.0E-04 rem, or 0.20 mrem. No health effects would be anticipated from these doses. 
Hazardous metals releases were calculated similar to radionuclide releases, with Table 6 (WERF administrative) maximum feed rates assumed. Resulting concentrations at the nearest worker, $100-\mathrm{m}$ worker, and MEI locations are presented in Table 12. Metal concentrations at the nearby worker and 100-m locations may exceed TLV's but would be below IDLHs. Acute worker exposures exceeding TLV values may produce symptoms such as irritation of the respiratory tract, redness and swelling of the mouth and gums, sweating, thirst, metallic taste, headache, digestive disorders and muscle pain. Exposures below IDLH values would not incapacitate workers such that they would be unable to evacuate or don protective equipment. Concentrations at the MEI location would be about $1 / 1000$ of those at the 100-m location, and below all TLVs. The accident would trigger system and radiation monitor alarms so that employees would immediately evacuate the facility or don protective equipment and provide emergency response.

\subsubsection{Ash Handling Spill}

Two spill scenarios were evaluated for a single 269-1 drum of ash: 1) a spill in the ash handling room, which is a worst-case scenario for a worker; and 2) a spill outside while loading a drum onto a truck, which exposes downwind receptors. The estimated probability of occurrence for each ash spill scenario is $4.0 \mathrm{E}-05 / \mathrm{yr}$. The spills release radioactive and hazardous metal particulates. The ash drum is assumed to contain $0.26 \mathrm{Ci}$, distributed among Table 2 nuclides (except for carbon-14,

Table 12. Estimated metal concentrations resulting from the baghouse/HEPA fire accident.

\begin{tabular}{lccccc}
\hline \multicolumn{1}{c}{ Metal } & $\begin{array}{c}\text { Worker } \\
\left(\mathrm{mg} / \mathrm{m}^{3}\right)\end{array}$ & $\begin{array}{c}100-\mathrm{m} \\
\text { concentration } \\
\left(\mathrm{mg} / \mathrm{m}^{3}\right)\end{array}$ & $\begin{array}{c}\mathrm{WLH} \mathrm{H}^{\mathrm{a}} \\
\left(\mathrm{mg} / \mathrm{m}^{3}\right)\end{array}$ & $\begin{array}{c}12.1 \mathrm{~km} \mathrm{NSB} \\
\text { concentration } \\
\left(\mathrm{mg} / \mathrm{m}^{3}\right)\end{array}$ & $\begin{array}{c}\text { TLV/PEL } \\
\left(\mathrm{mg} / \mathrm{m}^{3}\right)\end{array}$ \\
\hline Arsenic & $6.9 \mathrm{E}-01$ & $2.8 \mathrm{E}-02$ & $1.00 \mathrm{E}+02$ & $2.7 \mathrm{E}-05$ & $1.0 \mathrm{E}-02^{\mathrm{d}}$ \\
Beryllium & $1.1 \mathrm{E}+00$ & $4.2 \mathrm{E}-02$ & $1.00 \mathrm{E}+01$ & $4.1 \mathrm{E}-05$ & $2.0 \mathrm{E}-03^{\mathrm{e}}$ \\
Cadmium & $1.6 \mathrm{E}+00$ & $6.4 \mathrm{E}-02$ & $5.00 \mathrm{E}+01$ & $6.1 \mathrm{E}-05$ & $1.0 \mathrm{E}-02^{\mathrm{e}}$ \\
Chromium & $2.1 \mathrm{E}-01$ & $8.5 \mathrm{E}-03$ & $--^{\mathrm{c}}$ & $8.2 \mathrm{E}-06$ & $5.0 \mathrm{E}-02^{\mathrm{e}}$ \\
Antimony & $1.6 \mathrm{E}+00$ & $6.4 \mathrm{E}-02$. & $8.00 \mathrm{E}+01$ & $6.1 \mathrm{E}-05$ & $5.0 \mathrm{E}-01^{\mathrm{e}}$ \\
Barium & $1.4 \mathrm{E}+00$ & $5.9 \mathrm{E}-02$ & $1.10 \mathrm{E}+03$ & $5.7 \mathrm{E}-05$ & $5.0 \mathrm{E}-01^{\mathrm{e}}$ \\
Mercury & $1.9 \mathrm{E}+00$ & $6.4 \mathrm{E}-02$ & $2.80 \mathrm{E}+01$ & $6.1 \mathrm{E}-05$ & $3.0 \mathrm{E}-02^{\mathrm{f}}$ \\
Lead & $1.6 \mathrm{E}+00$ & $7.8 \mathrm{E}-02$ & $7.00 \mathrm{E}+02$ & $7.5 \mathrm{E}-05$ & $5.0 \mathrm{E}-02^{\mathrm{d}}$ \\
Silver & $1.4 \mathrm{E}+00$ & $5.9 \mathrm{E}-02$ & $--^{\mathrm{c}}$ & $5.7 \mathrm{E}-05$ & $1.0 \mathrm{E}-02^{\mathrm{e}}$ \\
Thallium & $1.6 \mathrm{E}+00$ & $6.4 \mathrm{E}-02$ & $2.00 \mathrm{E}+01$ & $6.1 \mathrm{E}-05$ & $1.0 \mathrm{E}-01^{\mathrm{e}}$ \\
\hline
\end{tabular}
a. NIOSH, 1990.
b. NSB-nearest site boundary.
c. No IDLH value exists for this metal.
d. OSHA PEL (29 CFR 1910.1000).
e. TWA (ACGIH, 1991).
f. STEL (ACGIH, 1991). 
hydrogen-3, and iodine-129, which volatilize and are not present in ash), which would give a 500mrem/hr dose rate on contact. This dose rate is the maximum allowed for disposal at RWMC.

4.3.3.1 Spill in Ash Handling Room. The spill in the ash handling room is assumed to occur when an operator accidentally tips over a full ash drum during an ash transfer operation. Personnel do not wear respiratory protection devices in this area and it is conservatively assumed that it takes the workers approximately 10 minutes to exit the room. The workers are exposed to respirable particulates containing radionuclides and heavy metals. The calculated release from this accident is 2.6E-04 $\mathrm{Ci}$ of radioactivity distributed among Table 2 nuclides (except for carbon-14, tritium, and iodine-129, which volatilize and are not present in ash). This would result in a dose to the worker of 1.1 rem. No health effects would be anticipated from this dose.

The calculated concentrations of resuspended metals in the ash handling room from this accident are presented in Table 13. If this accident scenario occurred, workers might be exposed to beryllium, cadmium, antimony, mercury, and thallium concentrations that exceed IDLH limits . Worker exposures would be minimized by immediate evacuation from the ash handling room. Such evacuation normally requires only a few seconds. Depending on actual metal concentrations in the ash and the duration of inhalation exposures, effects on workers could result in symptoms ranging

Table 13. Estimated metals concentrations at receptor locations resulting from ash spill releases.

\begin{tabular}{|c|c|c|c|c|c|c|}
\hline & Metal & $\begin{array}{l}\text { Worker } \\
\left(\mathrm{mg} / \mathrm{m}^{3}\right)\end{array}$ & $\begin{array}{c}100-\mathrm{m} \\
\text { concentration } \\
\left(\mathrm{mg} / \mathrm{m}^{3}\right)\end{array}$ & $\underset{\left(\mathrm{mg} / \mathrm{m}^{3}\right)}{\mathrm{DLH}^{\mathrm{a}}}$ & $\begin{array}{c}12.1 \mathrm{~km} \\
\mathrm{NSB}^{\mathrm{b}} \\
\text { concentration } \\
\left(\mathrm{mg} / \mathrm{m}^{3}\right)\end{array}$ & $\begin{array}{c}\text { TLV/PEL } \\
\left(\mathrm{mg} / \mathrm{m}^{3}\right)\end{array}$ \\
\hline & Arsenic & $7.2 \mathrm{E}+01$ & 4.1E-02 & $1.00 \mathrm{E}+02$ & $3.9 \mathrm{E}-05$ & $1.0 \mathrm{E}-02^{\mathrm{d}}$ \\
\hline & Beryllium & $1.3 E+02$ & 7.2E-02 & $1.00 \mathrm{E}+01$ & 7.0E-05 & $2.0 \mathrm{E}-03^{\mathrm{e}}$ \\
\hline & Cadmium & 1.7E+02 & $9.6 E-02$ & $5.00 \mathrm{E}+01$ & 9.3E-05 & $1.0 \mathrm{E}-02^{\mathrm{e}}$ \\
\hline & Chromium & $2.6 E+01$ & $1.4 E-02$ & $-^{c}$ & $1.4 \mathrm{E}-05$ & $5.0 \mathrm{E}-02^{\mathrm{e}}$ \\
\hline & Antimony & $1.7 \mathrm{E}+02$ & $9.6 \mathrm{E}-02$ & $8.00 \mathrm{E}+01$ & $9.3 E-05$ & $5.0 \mathrm{E}-01^{\mathrm{e}}$ \\
\hline & Barium & $1.7 \mathrm{E}+02$ & 9.6E-02 & $1.10 E+03$ & 9.3E-05 & $5.0 \mathrm{E}-01^{\mathrm{e}}$ \\
\hline & Lead & $1.7 \mathrm{E}+02$ & 9.6E-02 & $7.00 E+02$ & 9.3E-05 & $5.0 \mathrm{E}-02^{\mathrm{d}}$ \\
\hline & Mercury & $1.7 \mathrm{E}+02$ & $9.6 \mathrm{E}-02$ & $2.80 \mathrm{E}+01$ & 9.3E-05 & $3.0 \mathrm{E}-02^{\mathrm{f}}$ \\
\hline & Silver & $1.7 \mathrm{E}+02$ & 9.6E-02 & $-^{c}$ & 9.3E-05 & $1.0 \mathrm{E}-02^{\mathrm{e}}$ \\
\hline & Thallium & $1.7 \mathrm{E}+02$ & 9.6E-02 & $2.00 \mathrm{E}+01$ & 9.3E-05 & $1.0 \mathrm{E}-01^{\mathrm{e}}$ \\
\hline a. & \multicolumn{6}{|c|}{ NIOSH, 1990.} \\
\hline b. & \multicolumn{6}{|c|}{ NSB-nearest site boundary. } \\
\hline c. & \multicolumn{6}{|c|}{ No IDLH value exists for this metal. } \\
\hline d. & \multicolumn{6}{|c|}{ OSHA PEL (29 CFR 1910.1000). } \\
\hline e. & \multicolumn{6}{|c|}{ TWA (ACGIH, 1991). } \\
\hline f. & \multicolumn{6}{|c|}{ STEL (ACGIH, 1991). } \\
\hline
\end{tabular}


from irritation of the eyes, nose, throat, and skin; breathing difficulty and coughing to blood changes, organ and nerve damage, coma, or death.

4.3.3.2 Spill Outside. For the ash spill outside the building, it is assumed that $0.1 \%$ of the ash is resuspended over a 1-hour period and dispersed downwind. Receptors are conservatively assumed to be exposed for the entire 1 hour. The radiation dose to the $100-\mathrm{m}$ worker would be 7.0E-04 rem (0.70 mrem), and to the MEI would be $2.0 \mathrm{E}-06 \mathrm{rem}$ ( $2.0 \mathrm{E}-03 \mathrm{mrem})$. No health effects would be anticipated from these doses.

The calculated concentrations of resuspended metals at the $100-\mathrm{m}$ and MEI locations from this accident are also presented in Table 13. All metal concentrations at the $100-\mathrm{m}$ and MEI locations would be below TLV and IDLH values.

\subsubsection{Compactor Fire}

In this scenario, a fire erupts in the compactor just after a bin has been filled. The probability of occurrence is estimated to be $9.0 \mathrm{E}-05 / \mathrm{yr}$. The fire is assumed to spread through the ventilation system and involve the contents of both baghouses and the HEPA filters. The high temperatures generated by the fire are conservatively assumed to cause the baghouse seals to fail and release activity into the sizing/compaction building. The fractional inventory at risk in the burning bin [0.1\% (Walker, 1986)] and the entrained activity in the baghouses are released to the building and then to the environment through an open door. Because the HEPA filters are located outside the exterior structure of the facility, their activity does not contribute to the activity released within the building. The release continues for 8 hours. A worker in the compactor room is exposed to the release for 10 minutes; a worker at $100 \mathrm{~m}$ and an MEI at the INEL boundary are assumed to be exposed for the entire 8 hours of the accident. Because no MLLW is processed in the compactor, this accident releases only radioactive contamination.

Given the maximum allowed radiation reading for a bin of $500 \mathrm{mrem} / \mathrm{hr}$ at $0.9 \mathrm{~m}$, the maximum curie content of the bin, as calculated by the Microshield code (Grove Engineering, 1988), would be $2.8 \mathrm{Ci}$ distributed among Table 8 nuclides. The release from the bin and baghouses/HEPA filters would be $1.0 \mathrm{E}-02 \mathrm{Ci}$ over the 8 -hour duration of the incident. From this release, the workers in the compactor room and at $100 \mathrm{~m}$ would receive doses of $6.6 \mathrm{E}-02$ rem ( $66 \mathrm{mrem})$ each. The dose to the MEI would be 1.1E-04 rem. No health effects would be anticipated from these doses.

\subsection{Impacts of Alternatives to the Proposed Action}

This section discusses potential impacts of the five alternatives introduced in Section 2.4. A comparative summary of the impacts associated with the alternatives is presented in Table 14.

\subsubsection{The No Action Alternative}

The no action alternative would require DOE to continue storing INEL MLLW in INEL storage facilities and to continue using WERF for LLW volume reduction. Continued MLLW storage would be required due to the RCRA Section 3004 (40 CFR 268.50) prohibition on land 
Table 14. Comparative impacts of proposed action and alternatives.

\begin{tabular}{|c|c|c|c|c|c|c|}
\hline Impact & $\begin{array}{l}\text { Proposed } \\
\text { action }\end{array}$ & $\begin{array}{c}\text { Alternative } 1 \\
\text { No Action (continue to } \\
\text { store INEL-generated } \\
\text { MLLW and use WERF to } \\
\text { incinerate, compact, and } \\
\text { size LLW) }\end{array}$ & $\begin{array}{l}\text { Alternative } 2 \\
\text { Treat MLLW by } \\
\text { methods other than } \\
\text { incineration and use } \\
\text { WERF to incinerate, } \\
\text { compact, and resize } \\
\text { LLW }\end{array}$ & $\begin{array}{l}\text { Alternative } 3 \\
\text { Dispose of LLW without } \\
\text { volume reduction and } \\
\text { continue to store MLLW }\end{array}$ & $\begin{array}{l}\text { Alternative } 4 \\
\text { Construct and operate a } \\
\text { new MLLW incinerator } \\
\text { and continue to } \\
\text { incinerate, compact, and } \\
\text { size LLW at WERF }\end{array}$ & $\begin{array}{l}\text { Alternative } 5 \\
\text { Treat MLLW at another } \\
\text { DOE incinerator and } \\
\text { continue to incinerate, } \\
\text { compact, and size LLW } \\
\text { at WERF }\end{array}$ \\
\hline $\begin{array}{l}\text { Environmental } \\
\text { compliance }\end{array}$ & $\begin{array}{l}\text { Would bring } \\
\text { LDR MLLW } \\
\text { into compliance } \\
\text { with RCRA }\end{array}$ & $\begin{array}{l}\text { Existing and future } \\
\text { generated INEL MLLW } \\
\text { would require continued } \\
\text { storage. }\end{array}$ & $\begin{array}{l}\text { Treatments other than } \\
\text { incineration may not } \\
\text { meet RCRA standards } \\
\text { for MLLW. During the } \\
\text { EPA approval process. } \\
\text { INEL generated MLLW } \\
\text { would require continued } \\
\text { storage. }\end{array}$ & $\begin{array}{l}\text { Existing and future } \\
\text { generated INEL MLLW } \\
\text { would require continued } \\
\text { storage. }\end{array}$ & $\begin{array}{l}\text { A new incinerator would } \\
\text { require a RCRA Part B } \\
\text { and State Air Permits. } \\
\text { RCRA compliant } \\
\text { MLLW treatment would } \\
\text { be delayed 5-10 years. } \\
\text { Existing and future } \\
\text { generated INEL MLLW } \\
\text { would require continued } \\
\text { storage. }\end{array}$ & $\begin{array}{l}\text { Compliance would be } \\
\text { similar to PA if other } \\
\text { DOE incinerators were } \\
\text { licensed to treat INEL } \\
\text { MLLW }\end{array}$ \\
\hline Socioeconomic & $\begin{array}{l}\text { Small work } \\
\text { force needed to } \\
\text { operate WERF }\end{array}$ & Similar to $\mathbf{P A}^{\mathrm{a}}$ & Similar to PA & Reduction in work force & $\begin{array}{l}\text { New MLLW incinerator } \\
\text { would operate } \\
\text { intermittently ( } 1-3 \\
\text { months/yr). Small } \\
\text { additional work force } \\
\text { may be needed during } \\
\text { campaigns if WERF } \\
\text { operates concurrently }\end{array}$ & Similar to $\mathbf{P A}$ \\
\hline Land use & No Change & $\begin{array}{l}\text { Possible increase for } \\
\text { storage of MLLW and } \\
\text { LLW awaiting treatment }\end{array}$ & $\begin{array}{l}\text { Possible increase for } \\
\text { storage of MLLW and } \\
\text { LLW awaiting treatment }\end{array}$ & $\begin{array}{l}\text { More land area needed } \\
\text { for storage of MLLW } \\
\text { and disposal of LLW }\end{array}$ & $\begin{array}{l}\text { Additional land would } \\
\text { be required for new } \\
\text { incinerator and } \\
\text { ingress/egress }\end{array}$ & Similar to PA \\
\hline Health effects & $\begin{array}{l}\text { Minor near } \\
\text { term risks, } \\
\text { lower long term } \\
\text { risks }\end{array}$ & $\begin{array}{l}\text { Near term risks would be } \\
\text { less than PA, long term } \\
\text { risks would be higher than } \\
\text { PA }\end{array}$ & $\begin{array}{l}\text { Near term risks would } \\
\text { be less than PA. Due to } \\
\text { the possibility of } \\
\text { reclaiming waste, long } \\
\text { term risks would be } \\
\text { higher than PA }\end{array}$ & $\begin{array}{l}\text { Increased near term risk } \\
\text { to workers and long-term } \\
\text { risk to } \\
\text { public/environment }\end{array}$ & $\begin{array}{l}\text { Near term effects would } \\
\text { be less than PA. LLW } \\
\text { transportation effects } \\
\text { would be avoided. } \\
\text { When new MLLW } \\
\text { incinerator becomes } \\
\text { operational, effects form } \\
\text { incinerating MLLW and } \\
\text { LLW would be similar } \\
\text { to PA. }\end{array}$ & $\begin{array}{l}\text { Processing risks would be } \\
\text { similar to PA. MLLW } \\
\text { transportation risks would } \\
\text { increase, LLW } \\
\text { transportation risks would } \\
\text { be avoided }\end{array}$ \\
\hline $\begin{array}{l}\text { Terrestrial } \\
\text { ecology }\end{array}$ & None & $\begin{array}{l}\text { Possible loss of habitat } \\
\text { due to expanded MLLW } \\
\text { storage }\end{array}$ & $\begin{array}{l}\text { Possible loss of habitat } \\
\text { due to expanded MLLW } \\
\text { storage }\end{array}$ & $\begin{array}{l}\text { Increased habitat loss for } \\
\text { expanded LLW disposal } \\
\text { facility }\end{array}$ & $\begin{array}{l}\text { Increased habitat loss } \\
\text { for construction of new } \\
\text { incinerator }\end{array}$ & None \\
\hline
\end{tabular}


Table 14. (continued).

\begin{tabular}{|c|c|c|c|c|c|c|}
\hline Impact & $\begin{array}{l}\text { Proposed } \\
\text { action }\end{array}$ & $\begin{array}{c}\text { Alternative } 1 \\
\text { No Action (continue to } \\
\text { store INEL-generated } \\
\text { MLLW and use WERF to } \\
\text { incinerate, compact, and } \\
\text { size LLW) }\end{array}$ & $\begin{array}{c}\text { Alternative } 2 \\
\text { Treat MLLW by } \\
\text { methods other than } \\
\text { incineration and use } \\
\text { WERF to incinerate, } \\
\text { compact, and resize } \\
\text { LLW }\end{array}$ & $\begin{array}{l}\text { Alternative } 3 \\
\text { Dispose of LLW without } \\
\text { volume reduction and } \\
\text { continue to store MLLW }\end{array}$ & $\begin{array}{c}\text { Alternative } 4 \\
\text { Construct and operate a } \\
\text { new MLLW incinerator } \\
\text { and continue to } \\
\text { incinerate, compact, and } \\
\text { size LLW at WERF }\end{array}$ & $\begin{array}{l}\text { Alternative } 5 \\
\text { Treat MLLW at another } \\
\text { DOE incinerator and } \\
\text { continue to incinerate, } \\
\text { compact, and size LLW } \\
\text { at WERF }\end{array}$ \\
\hline $\begin{array}{l}\text { Archeological and } \\
\text { historical sites } \\
\text {. }\end{array}$ & None & $\begin{array}{l}\text { Possible impacts due to } \\
\text { expanded MLLW storage }\end{array}$ & $\begin{array}{l}\text { Possible impacts due to } \\
\text { expanded MLLW } \\
\text { storage }\end{array}$ & $\begin{array}{l}\text { Possible impacts due to } \\
\text { expanded LLW disposal } \\
\text { facility and expanded } \\
\text { MLLW storage. }\end{array}$ & $\begin{array}{l}\text { Possible } \\
\text { impacts/mitigation } \\
\text { requirements depending } \\
\text { on new incinerator site }\end{array}$ & None \\
\hline $\begin{array}{l}\text { Accidents and } \\
\text { occupational risks }\end{array}$ & $\begin{array}{l}\text { Increased near } \\
\text { term risks due } \\
\text { to handling } \\
\text { MLLW and } \\
\text { from LLW } \\
\text { transportation } \\
\text { lower long term } \\
\text { risks due to } \\
\text { more stable } \\
\text { storage/disposal } \\
\text { form }\end{array}$ & $\begin{array}{l}\text { LLW transportation risks } \\
\text { less than PA; MLLW near } \\
\text { term risk is less than PA, } \\
\text { long term risk is greater } \\
\text { due to extended storage }\end{array}$ & $\begin{array}{l}\text { LLW transportation } \\
\text { risks less than PA. } \\
\text { MLLW near term risk is } \\
\text { less than PA, long term } \\
\text { risk is greater due to } \\
\text { extended storage }\end{array}$ & $\begin{array}{l}\text { Increased risk from } \\
\text { handting more containers } \\
\text { and from extended } \\
\text { storage of MLLW }\end{array}$ & $\begin{array}{l}\text { Increased risks from } \\
\text { continued MLLW } \\
\text { storage/monitoring until } \\
\text { treatment capacity is } \\
\text { available. Processing } \\
\text { risks would be similar to } \\
\text { PA for LLW and } \\
\text { MLLW (when new } \\
\text { MLLW incinerator } \\
\text { becomes operational). } \\
\text { LLW transportation } \\
\text { risks would be avoided. }\end{array}$ & $\begin{array}{l}\text { Processing risks would be } \\
\text { similar to PA. MLLW } \\
\text { transportation risks would } \\
\text { increase, LLW } \\
\text { transportation risks would } \\
\text { be avoided }\end{array}$ \\
\hline
\end{tabular}


disposal of untreated hazardous wastes. To minimize health and environmental threats, EPA promulgated treatment standards for these wastes.

RCRA requires prompt treatment of restricted hazardous waste to avoid the risks of future releases from extended storage. Hazardous wastes, subject to LDR requirements found in $40 \mathrm{CFR}$ 268 , must be treated to EPA requirements prior to disposal. Storage of MLLW waste is prohibited unless stored solely for the purpose of recovery, treatment, or disposal.

Expected annual doses to workers from proposed treatment would be 10 to $20 \mathrm{mrem} /$ person for each MLLW treatment campaign. However, if the MLLW continues to accumulate in storage facilities the dose to workers would increase based on weekly inspections of approximately one hour each giving a weekly dose of approximately $1 \mathrm{mrem}$ (an annual dose of approximately $52 \mathrm{mrem}$ ). Indefinite storage of MLLW could result in a higher annual worker dose than from proposed MLLW processing.

The no action alternative would not entail the risk associated with shipping the LLW to a commercial facility. However, continued treatment of the LLW at WERF would require storing, handling, and monitoring the LLW at INEL until the inventory is processed. Worker exposure to radioactivity during processing would be as low as reasonably achievable for these activities and well below DOE standards for occupationally related exposures.

\subsubsection{Treat MLLW By Methods Other Than Incineration and Continue Use of WERF to Incinerate, Compact, and Size LLW}

Stabilization and biological and chemical treatment have been considered as alternatives to MLLW incineration (DOE, 1992b). Stabilization would immobilize but not reduce the toxicity or the volume of the waste. Consequently, the potential for environmental contamination may still exist at the disposal site and the waste may have to be reclaimed at a later date. Because of the specificity of chemical and/or biological treatments, multiple processes would be required to process various waste forms and chemical compositions. Multiple processes would increase the likelihood for exposure to radioactive and hazardous wastes. Currently, incineration is the only EPA-approved, technology-based treatment standard for many hazardous wastes. Obtaining approval from the EPA for treatment methods other than incineration is possible; however, the demonstration and the approval process would delay MLLW treatment.

Continued storage and treatment of LLW at WERF would result in actions and environmental impacts corresponding to the no action alternative as discussed in Section 4.4.1.

\subsubsection{Dispose of LLW Without Volume Reduction and Continue to Store MLLW}

Continued storage of MLLW without treatment would have impacts as described in the no action alternative in Section 4.4.1. Storage of hazardous waste is not allowed under RCRA except to accumulate sufficient quantities to facilitate proper treatment, recovery, or disposal.

Prior to 1982, LLW was disposed of directly by shallow-land burial at RWMC. This practice was determined to be inefficient because many waste forms had high bulk densities or contained void spaces. Volume reduction of LLW would decrease the number of containers to be disposed of in 
the RWMC, but the radiation fields of the drums would be higher as a result of consolidation. Sending unprocessed LLW to RWMC would require more containers to be buried. Risks from spills, leaks, and exposures to workers resulting from handling accidents increase in proportion to the number of containers handled. Direct disposal would not use disposal space in RWMC efficiently, and the disposal capacity of RWMC would be reduced from the projected 21 years to approximately 7 years. Assuming continued generation of LLW, additional disposal sites would have to be developed sooner than under the proposed action. Additional disposal sites would require changes in both land use and environmental conditions at those sites.

In addition to risks to workers, NRC has examined the issue of relative risks to potential intruders and future populations from stabilized and unstabilized LLW. Stabilized waste was found to provide a reduction in risk over unstabilized waste ranging from a factor of 22 to 1,500 , depending on the scenario (NRC, 1982).

\subsubsection{Construct and Operate a New MLLW Incinerator and Continue to Incinerate, Compact, and Size LLW at WERF}

Under this alternative, no immediate treatment capacity would be available; a new incinerator would be constructed at INEL to treat MLLW and WERF would continue to process LLW. Two separate incinerators would result in substantial duplication of facilities at a much greater cost than the proposed action. Similarly, maintenance costs would be higher for two incinerators. This alternative would result in a higher potential for emissions to the environment during concurrent operations.

Separate incinerators would not significantly improve the existing WERF combustion efficiency or emissions. Consequently, separate incinerators would not provide an environmental protection advantage compared to WERF.

The construction of a new incinerator would also require a new RCRA permit and trial burn. In addition, an analysis would be required to determine if NESHAP approval would be necessary, a Prevention of Significant Deterioration analysis would be required and an application for an Idaho permit to construct would be prepared. DOE would be required to continue storing existing MLLW until the new facility became operational.

\subsubsection{Treat MLLW at Another DOE Incinerator and Continue to Incinerate, Compact, and Size LLW at WERF}

Existing or planned radioactive or mixed waste incinerators that may have the capability to process INEL MLLW are located at RFP, LANL, ORR, and SRS. The RFP and existing SRS incinerators are not currently operational. The ORR incinerator is not suitable for beta/gammacontaminated wastes and is scheduled to process onsite-generated wastes at or near capacity. The existing LANL pilot incinerator is permitted to treat only LANL-generated mixed transuranic waste. A consolidated incineration facility is being constructed at SRS to process hazardous and MLLW. The planned SRS facility is permitted only for SRS waste. Modifications to these permits, if granted, would require 3 to 5 years. Therefore, it is not anticipated that the SRP incinerator would be available to process INEL waste during the next 3 to 5 years. 


\title{
5. WERF PERMITS AND AGENCIES/PERSONS CONSULTED
}

Projects and facilities at the INEL must comply with applicable environmental protection requirements of the EPA, DOE, other federal agencies, and the State of Idaho. This section provides a list of existing and planned environmental documents and permits, and regulatory agency staff who have been consulted during the preparation and approval processes.

Document/Permit

NESHAP Approval to

Construct

RCRA Parts A \& B Permits State of Idaho
(Permits and

Enforcement Division)

Contact

EPA (Region X)

J. Leitch

R. Poeton

R. Steger

B. Monson

IDEQ

M. Bauer

Idaho Air Permit

\author{
CDEQ
}

D. Pitman 
June 1994

\section{REFERENCES}

American Conference of Governmental Industrial Hygienists (ACGIH), 1991. Guide to Occupational Exposure Values-1991, Cincinnati, Ohio.

Atwood, C. L., 1992. Statistical Analysis of Radiological Data from WERF Fly Ash, EGG-SR-10233.

Berry, W. J. and J. L. Petty, 1990. Summary of Available Baseline Environmental Information for the Radioactive Waste Management Complex at the Idaho National Engineering Laboratory, EGG-WM-9063, EG\&G Idaho, Inc., Idaho Falls, Idaho.

Bowman et al., 1984. INEL Environmental Characterization Report, EGG-NPR-6688, EG\&G Idaho, Inc., Idaho Falls, Idaho.

DOE (U.S. Department of Energy), 1980. Final Environmental Impact Statement, U.S. Spent Fuel Policy, DOE/EIS-0015, Assistant Secretary for Nuclear Energy, Washington, D.C.

DOE (U.S Department of Energy), 1988. Radioactive Waste Management. DOE Order 5820.2A, September 26, 1988. Attachment VI-1, Page C3-2, Idaho Field Office, Idaho Falls, Idaho.

DOE (U.S. Department of Energy), 1991a. INEL Low-Level Waste Acceptance Criteria, DOE/D-10112, Rev. 4, Idaho Field Office, Idaho Falls, Idaho.

DOE (U.S. Department of Energy), 1991b. The Idaho National Engineering Laboratory Site Environmental Report for Calendar Year 1990. DOE/ID-12082(90), Idaho Field Office, Idaho Falls, Idaho.

DOE (U.S. Department of Energy), 1991c. 1990 INEL National Emission Standard for Hazardous Air Pollutants Annual Report. DOE/ID-10342, Idaho Field Office, Idaho Falls, Idaho.

DOE (U.S. Department of Energy), 1992a. 1991 INEL National Emission Standard for Hazardous Air Pollutants Annual Report. DOE/ID-10342(915), Idaho Field Office, Idaho Falls, Idaho.

DOE (U.S. Department of Energy), 1992b. Environmental Assessment Consolidated Incineration Facility Savannah River Site. DOE/EA-0400, 57 FR 29299.

Elder, J. C. et al., 1986. A Guide to Radiological Accident Considerations for Siting and Design of DOE Nonreactor Nuclear Facilities, Los Alamos National Laboratory, LA-10294-MS, Los Alamos, New Mexico.

EPA (U.S. Environmental Protection Agency), and NCI (National Cancer Institute), 1983. U.S. Cancer Mortality Rates and Trends, 1950-1979. EPA-600/1-83-015C.

EPA (U.S. Environmental Protection Agency), 1989a. The Clean Air Act Assessment Package-1988 (CAP-88), Office of Radiation Programs. 
EPA (U.S. Environmental Protection Agency), 1989b. Emission Standards for Hazardous Air Pollutants; Radionuclides; Final Rule and Notice of Reconsideration, 40 CFR 61, Federal Register, December 15, 1989.

EPA (U.S. Environmental Protection Agency), 1989c. Risk Assessment Guidance for Superfund, Volume 1, Human Health Evaluation Manual (Part A), EPA-540-1-89-002.

EPA (U.S. Environmental Protection Agency), 1989d. "Guidance on Metals and Hydrogen Chloride Controls for Hazardous Waste Incinerators", Volume IV of the Hazardous Waste Incineration Guidance Series, EPA-530/SW-90-004, August 1989.

EPA (U.S. Environmental Protection Agency), 1990. "Standards for Owners and Operators of Hazardous Waste Incinerators and Burning of Hazardous Wastes in Boilers and Industrial Furnaces," Federal Register Vol. 55 \#82.

EPA (U.S. Environmental Protection Agency), 1992. "Health Effects Assessment Summary Tables", Annual FY 1992 OERR 9200.6-303-(92-1).

Grove Engineering, Inc., 1988. Microshield Version 3, Rockville, Maryland.

Lobdell, C. H., 1992. USFWS to C. R. Nichols, DOE-ID Department of Energy Species List Update, SP\# 1-4-93-SP-84/506.0000.

Moseley, R. and C. Groves, 1992. Rare, Threatened and Endangered Plants and Animals of Idaho, Conservation Data Center, Nongame and Endangered Wildlife Program, Idaho Department of Fish and Game.

NIOSH (National Institute of Occupational Safety and Health), 1990. "Pocket Guide to Chemical Hazards", DHHS (NIOSH) Publication No. 90-117.

NRC (Nuclear Regulatory Commission), 1977. Final Environmental Statement on the Transportation of Radioactive Material by Air and Other Modes, Office of Standards Development, NUREG-0170, Volume 1.

NRC (Nuclear Regulatory Commission), 1982. Final Environmental Impact Statement (FEIS), Licensing Requirements for Land Disposal of Radioactive Waste, NUREG-0945, Volume 1.

NRC (Nuclear Regulatory Commission), 1991. Standards for Protection Against Radiation, 56 FR 23363, May 21, 1991.

Rao, R. K, E. L. Wilmot, and R. E. Luna, 1981. Nonradiological Impacts of Transporting Radioactive Material, SAND81-1703, Sandia National Laboratories, Albuquerque, New Mexico. 
June 1994

Reed, W. G., J. W. Ross, B. L. Ringe, and R. N. Holmer, 1987. Archaeological Investigations on the Idaho National Engineering Laboratory: 1984-1985, Revised Edition, Swanson/Crabtree Anthropological Research Laboratory Reports of Investigations No. 87-2, Pocatello, Idaho.

Reynolds, T. D., J. W. Connelly, D. K. Halford, and W. J. Arthur, 1986. Vertebrate Fauna of the Idaho National Environmental Research Park, Great Basin Naturalist 46, pp. 513-527.

Rothman, R. S., 1992. letter to Armina Nolan, EPA Region X, AM-SES-ESB-32, January 31, 1992.

Schofield, W. D., 1992a. Earthquake Analysis for WERF, Engineering Design File No. WERF-0164, EG\&G Idaho, Inc., Idaho Falls, Idaho.

Schofield, W. D., 1992b. North Stack HEPA and Baghouse Filter Fire, Engineering Design File No. WERF-0159, EG\&G Idaho, Inc., Idaho Falls, Idaho.

Schofield, W. D., 1992c. Ash Handling Spill, Engineering Design File No. WERF-0154, EG\&G Idaho, Inc., Idaho Falls, Idaho.

Schofield, W. D., 1992d. WERF Compactor Fire, Engineering Design File No. WERF-0155, EG\&G Idaho, Inc., Idaho Falls, Idaho.

Staley, C. S., 1992a. CAP-88 Runs Supporting Source Term Development for WERF Restart, Engineering Design File No. WERF-91-001.2, Revision 1, EG\&G Idaho, Inc., Idaho Falls, Idaho.

Staley, C. S., 1992b. Derived Source Limits for Nonradiological Waste Constituents for the WERF Incinerator, Engineering Design File No. WERF-91-001.1, EG\&G Idaho, Inc., Idaho Falls, Idaho.

Start, G. E., 1993. Letter to J. Edson, Reference Meteorological Values for PBF Dispersion Calculations, January 22, 1993.

Sterling, R. J., 1992. Application for a State of Idaho Permit to Construct an Air Pollution Source at the Idaho National Engineering Laboratory Power Burst Facility Area: The Waste Experimental Reduction Facility, EGG-WMO-10355.

U.S. Bureau of Land Management, 1990. Final Environmental Impact Statement: USPCI Clive Incineration Facility, Salt Lake District Office, Salt Lake City, Utah.

U.S. Department of Commerce, Bureau of Census, 1990. Census of Population and Housing, 1990, Public Law 94-171 Data on CD-ROM Technical Documentation (prepared 1991).

Walker, E., 1986. A Summary of Parameters Affecting the Release and Transport of Radioactive Material from an Unplanned Incident, BNFO-81-2.

Wenzel, D. R., 1990. Interim Users Manual for RSAC-4, Radiological Safety Analysis Computer Program, Version 4.03. 
Wolfe, T. A, 1984. The Transportation of Nuclear Materials, SAND84-0062, Sandia National Laboratories, Albuquerque, New Mexico. 
June 1994

\section{GLOSSARY}

Accepted Ambient Levels for a Carcinogen (AALC)-Pertaining to carcinogens with a unit risk factor (URF), the AALC is the concentration at which the probability of excess cancers over a lifetime is one in one million or less. For carcinogens that do not have an established URF, the AALC is the detection limit.

Baghouse Fly Ash—Finely divided particles of ash from incinerator flue gases that are entrapped in a housing containing fabric filters.

Characteristic Hazardous Waste-A solid waste exhibiting any of the following characteristics as defined in 40 CFR 261, Subpart C: ignitability, corrosivity, reactivity, and toxicity.

Contact-Handled Low-Level Waste-Low-level waste with a radiation field of less than 500 mrem at $3 \mathrm{ft}$.

Controlled-Air Incinerator-An incinerator in which the combustion air into the incinerator is controlled.

Criteria Pollutants-Substances for which national ambient air quality standards are established.

Cultural Resources-Areas or objects that are of cultural significance to Native Americans and other defined ethnic groups.

Decommissioning-The process of removing a facility from operation, followed by decontamination, entombment, dismantlement, or conversion to another use.

Decontamination-The removal of unwanted material (typically radioactive material) from facilities, soils, or equipment by washing, chemical action, mechanical cleaning, or other techniques.

Destruction and Removal Efficiency (DRE)-The fraction of hazardous waste that is destroyed by a hazardous waste incinerator.

Effective Dose Equivalent (EDE)-The sum of the products of absorbed dose and appropriate factors to account for differences in biological effectiveness due to the quality of radiation and its distribution in the body.

Environmental Protection Agency Technology Based Treatment Standard—Treatment technologies that have been shown through actual use to yield the greatest environmental benefit among competing technologies that are practically available.

Etiologic Agents-The cause of a disease.

. Filtration Residue-Particulates that are filtered out of offgas. 
Fumigation-Fumigation is a meteorological phenomenon that occurs when the temperature inversion at the surface is being broken up by surface heating. The inversion breakup creates moderately unstable conditions under an inversion lid and, thereby, limits vertical dispersion to the area between the ground and the base of the inversion.

Hazardous Waste-Any solid, semisolid, liquid, or gaseous waste that is ignitable, corrosive, toxic, or reactive as defined by the RCRA and identified or listed in 40 CFR 261.

Hazardous Constituents-Components of waste that are defined by the Environmental Protection Agency (EPA) as hazardous.

High Efficiency Particulate Air (HEPA) Filter-Filters having a minimum 99.97\% removal efficiency for 0.3 micron particles.

Immediately Dangerous to Life and Health (IDLH)-The maximum concentration from which one could escape within $30 \mathrm{~min}$ without any escape-impairing symptoms or irreversible health effects.

Incinerable Waste-Waste that qualifies for incineration as a treatment.

Incineration-A treatment technology using combustion to destroy organic constituents and reduce the volume of wastes.

Incinerator Bottom Ash-The ash that does not leave the incinerator through offgas.

Incinerator Offgas-Air, gases, and particulates that leave the incinerator chamber and are subject to filtration.

Land Disposal Restrictions (LDRs)-Provisions of Hazardous and Solid Waste Amendments requiring phased-in treatment of hazardous wastes before disposal.

Listed Hazardous Wastes-A hazardous waste that meets the requirements of 40 CFR 261 Subpart D.

Low-Level Waste (LLW)-Radioactive waste not classified as high-level waste, transuranic waste, spent nuclear fuel, or byproduct material.

Maximally Exposed Individual (MEN- A hypothetical member of the public who receives the maximum EDE from exposure to ambient air radionuclide concentrations from a facility.

Mixed Low-Level Waste (MLLW)-Waste containing both low-level radioactive and hazardous constituents. The radioactive constituents are regulated by the Atomic Energy Act and the hazardous components are regulated under RCRA.

National Emission Standards for Hazardous Air Pollutants (NESHAP)—Clean Air Act limits for release of hazardous pollutants for which no ambient air quality standard is applicable (40 CFR 61). 
June 1994

National Environmental Policy Act (NEPA)-Public Law 91-190 and CEQ implementing regulations in 40 CFR 1500-1508.

Permissible Exposure Limit (PEL)-An exposure limit that is published and enforced by OSHA as a legal standard.

Prevention of Significant Deterioration (PSD)-Part C of the Clean Air Act that establishes a policy of limiting degradation of air quality based upon classification of areas.

Radioactive Material License (RML)-Issued by the NRC to allow receipt, possession, use, transfer, or delivery of any source, by-product, or special nuclear material.

Radioactive Waste-A solid, liquid, or gaseous material of negligible economic value that contains radionuclides in excess of threshold quantities. Does not include material contaminated by radionuclides from nuclear weapons testing.

Regulated Hazardous Constituents-Constituents that are regulated under 40 CFR 261.

Scientific Notation-A widely used floating-point system in which numbers are expressed as products consisting of a number between 1 and 10 multiplied by an appropriate power of 10. 1.0E-01 is equivalent to $10^{-1}$ or $0.1 ; 1.22 \mathrm{E}-01$ equals $0.12 ; 1.52 \mathrm{E}-04$ equals $0.000152 ; 1.76 \mathrm{E}+01$ equals 17.6 ; and $1.00 \mathrm{E}+00$ equals 1.00 .

Scrubber Effluent-Offgas scrubber solution and contamination removed by a scrubber.

Short Term Exposure Limit (STEL)-Maximum airborne concentrations of a substance to which a worker could be exposed for a continuous exposure period of 15 minutes without suffering from prolonged adverse health effects.

Sizable-Waste objects that can be cut into smaller pieces for efficient packaging and disposal.

Slope Factor-The increase in lifetime cancer risks per unit dose of a carcinogen.

Stabilization-The mixing of waste with reagents which reduces the leachability of the metals or inorganics in the waste.

Sv-Sievert $(1 \mathrm{~Sv}=100 \mathrm{rem})$

Threshold Limit Values (TLV)-Concentrations of airborne substances published by ACGIH that represent conditions where nearly all workers may be exposed without adverse health effects.

Time Weighted Average (TWA)-A time-weighted average concentration for a normal 8-hour workday and 40-hour work week to which nearly all workers may be repeatedly exposed, day after day without adverse effect. 
Trial Burn-As required under RCRA and Toxic Substances Control Act (TSCA) to demonstrate the incineration efficiency of waste materials at different temperatures; the performance test which establishes the operating conditions and parameters that appear in the final TSCA approval/RCRA permit.

Volatile Organic Compound (VOC)-Carbon based compounds that evaporate at room temperature. Any reactive organic compounds as defined in 40 CFR 60.2.

Waste Acceptance Criteria (WAC)-The criteria used to determine if waste is acceptable for receipt. 


\section{Appendix A}

Responses to the State of Idaho and the Shoshone-Bannock Tribes Comments 
June 1994

A-2 
June 1994

\section{Appendix A}

\section{Responses to the State of Idaho and the Shoshone-Bannock Tribes Comments}

In accordance to the Department of Energy, Idaho Operations Office policy, the draft Idaho National Engineering Laboratory Low-Level and Mixed Waste Processing environmental assessment was provided to the State of Idaho and the Shoshone and Bannock Tribes during April 1993, for preapproval reviews. This appendix contains copies of Idaho Department of Health and Welfare and The Shoshone-Bannock Tribes comment letters and text of comments and Department of Energy responses.

\section{Response to Comments}

Relationship of the proposed action to Idaho National Engineering Laboratory (INEL) Facilities Compliance Act and alpha low-level waste (LLW) management and Federal activities.

Comments and transmittal letters from the State of Idaho and the Shoshone-Bannock Tribes reflect possible misunderstanding regarding the relationship between the proposed action in this environmental assessment (EA) and other INEL mixed waste management and planning activities. The following clarifies this relationship.

The historic mission of the INEL's Waste Experimental Reduction Facility (WERF) has been to provide low-level waste (LLW) volume reduction and stabilization. The proposed action addressed in the EA would expand the WERF mission to include treating mixed LLW to comply with Resource Conservation and Recovery Act requirements for continued storage or land disposal. Treatment of mixed LLW from offsite, generators at WERF would be limited to less than $5 \mathrm{~m}^{3}$ per year. Supplementary commercial LLW volume reduction processing is needed to eliminate INEL operational problems and risks associated with the accumulated LLW inventory. The supplemental commercial treatment of LLW will not impact the mission of WERF.

The Federal Facilities Compliance Act (FFCA) requires the Department of Energy (DOE) to prepare specific mixed waste inventory reports and treatment plans for the State of Idaho and the Environmental Protection Agency (EPA). The proposed action addressed in the EA is consistent with the WERF mission described in the INEL's section of the FFCA 180-day report. The volume of mixed LLW for incineration at WERF has been updated in the EA from $60 \mathrm{~m}^{3}$ to $72 \mathrm{~m}^{3}$ for consistency with the 180-day report. Future DOE programs may create a need for additional modifications to the WERF mission. If that occurs, additional National Environmental Policy Act (NEPA) analysis and documentation will be prepared.

A recent announcement appeared in the Commerce Business Daily for an expression of interest for the private sector to provide characterization, transportation, and treatment services for radioactive/hazardous solid waste.This announcement is not associated with the EA proposed action 
June 1994

and does not impact the current or proposed mission of WERF. The purpose of this announcement was to identify potential alternatives for treating the INEL inventory of alpha-contaminated LLW stored at the Radioactive Waste Management Complex (RWMC). Much of this waste is also mixed waste, but it cannot be treated at WERF or any currently available commercial facilities.

\section{Response to State of Idaho Comments}

\section{Document Justification}

\section{Comment}

The level of documentation justification is inadequate for this proposal based upon review of available information. The Department bases an EA, in part, upon the continuity of the proposed actions. WERF is expanding from MLLW treatment demonstrations to productionscale campaigns. EA p. 8. In the Justification section, DOE states eight mixed low-level waste (MLLW) campaigns occurred during 1989 and 1990. However, no NEPA documents evaluating these campaigns were identified in the predecisional draft or in the list of NEPA documents previously provided. Further, the operations of WERF, established in 1982, were evaluated in two Environmental Evaluations (EE) dated June 1, 1981 and June 1, 1982. Neither EE identified impacts associated with hazardous waste incineration. Impacts for the hazardous component of mixed waste would have been identified in a hazardous waste-only burn had it been done.

\section{Response}

An EA was determined to be the appropriate level of NEPA documentation for this proposed action. As stated in Section 1.5 of the EA, the proposed action does not fit 10 CFR 1021 Subpart D typical classes of actions, and there are extraordinary circumstances that may affect the significance of the proposed action. Accordingly, DOE determined to prepare an EA and on the basis of the EA, determine whether to prepare an environmental impact statement (EIS) or to issue a Finding Of No Significant Impact (FONSI).

The eight MLLW campaigns that occurred during 1989 and 1990 were conducted in accordance with a March 1986 document, "Hazardous and Radioactive Mixed Waste Treatment Supplement" which amended the 1982 EE documents for WERF. The supplement was prepared before the mixed waste demonstrations, and it demonstrated that there would be no significant impacts.

\section{Comment}

In comments sent to the Department in December 1992, the State suggested handling this project in an expanded public forum. No commitment to this approach was made by DOE. As stated earlier, whether this project should be handled as an EA or EIS is debatable. The State will continue to review this issue in light of the predecisional draft and evaluation of the 
implementation plan developed for the Environmental Restoration and Waste Management (ER\&WM) EIS.

\section{Response}

In response to requests from citizens for more participation in INEL activities including waste management and your request for an expanded public forum, Department of Energy, Idaho Operations Office (DOE-ID) initiated a series of public participation events that include information/discussion of INEL LLW and mixed LLW management plans. The activities which were initiated during the 3rd quarter of 1992, include news releases, INEL tours, INEL outreach offices, and presentations to civic groups, business leaders, public officials, special interest groups and school classes in communities across the State. In addition, a series of briefings in communities across the State were held during May and June, 1993. These briefings are organized to discuss various topics of interest to the public including options for mixed waste processing and LLW disposal. The briefings include a video and fact sheets on WERF. The series of briefings and open houses will be conducted on a semiannual basis with updates occurring through newsletters and ongoing outreach.

The EA has been provided to the State and Shoshone and Bannock Tribes for pre-release reviews in compliance with agreements. Based on the analysis presented in the EA, DOE plans to issue a proposed FONSI for a 30-day public review and comment period. Copies of the EA and proposed FONSI will be distributed to the Idaho congressional delegation, State and local officials, INEL Outreach Offices, interested organizations, news media and public libraries. In addition, the proposed FONSI will be published in the Federal Register. DOE will evaluate the comments received as a result of the public review process and determine whether to issue a FONSI or if the proposed action constitutes a major Federal action significantly affecting the quality of the human environment, within the meaning of NEPA.

\section{Purpose and Need}

\section{Comment}

DOE proposes this action because of a shortage of MLLW treatment and disposal facilities, accumulating LLW requiring expeditious processing and disposal, and selecting treatment capabilities for LLW not available at WERF. EA, p. 8. The State's review of the supporting information leads to a different conclusion; the proposal is an effort to expand MLLW treatment in order to begin processing off-site MLLW.

\section{Response}

The purpose of the proposed action is stated in section 1.6, "Relationship to Other NEPA Reviews": "The proposed action at WERF does not include processing LLW or MLLW from sources other than INEL, with the exception of very limited quantities $\left(<5 \mathrm{~m}^{3} / \mathrm{yr}\right)$ explained further in this document. The use of WERF as a regional incinerator to process LLW or MLLW from non-INEL sources, such as other DOE facilities is not within the scope of the 
proposed action. Such an action (if proposed as future alternative) would be addressed in the Office of Environmental Restoration and Waste Management (EM) programmatic environmental impact statement (PEIS), the INEL ER\&WM EIS, and/or other appropriate NEPA documentation." The proposed action at WERF is not an effort to change the WERF's current mission from processing INEL-generated waste to processing offsite-generated waste. The EA clearly limits offsite waste to $<5 \mathrm{~m}^{3} / \mathrm{yr}$.

\section{Comment}

Incinerable MLLW is less than $0.3 \%$ of the accumulated INEL MLLW. It is less than $3 \%$ of the estimated annual generation of MLLW. It is also a small percentage of total incinerable wastes $\left[\left(60 \mathrm{~m}^{3} \mathrm{MLLW}\right) /\left(9560 \mathrm{~m}^{3} \mathrm{Total}\right)=0.01 \%\right]$. To sacrifice $L L W$ treatment capacity for a small volume of MLLW does not appear to be a rational choice. Even with a total projected inventory of $L L W$ of $9,500 \mathrm{~m}^{3}$, processing at historic capacities would require slightly more than three years. DOE estimates three to five years for the same wastes. Adding two months for MLLW treatment should not increase the time for the total inventory by two years.

\section{Response}

The proposed action would offset approximately 60 days of LLW processing to treat the MLLW backlog and approximately 40 days per year to treat the newly generated MLLW. The preferred action would treat the existing backlog of LLW at a commercial facility and allow for flexible continued commercial treatments as needed. As identified in Section 1.3, the treatment of this backlog of waste "would minimize the risk of waste storage container deterioration and radiological releases, and maintain as low as reasonably achievable radiation fields and worker doses at WERF." The volume reduction provided would comply with the RWMC waste acceptance criteria and conserve LLW disposal space.

Section 2.4.1, "No Action Alternative", states the September 1993 inventory of $9,500 \mathrm{~m}^{3}$ of LLW would require 3 to 5 years for volume reduction/treatment. The 40 days per year for MLLW treatment does not increase the time for treatment of the total inventory by two years. Rather, this is based on the inventory and generation rates identified in Table 1. The projected on-going generation rates of $340 \mathrm{~m}^{3} /$ month of LLW over the three year period would create an additional volume of $12,240 \mathrm{~m}^{3}$ of LLW that would require processing. DOE conservatively expects that this total volume of $L L W$ (existing inventory plus on-going generation) would take 3 to 5 years to process.

\section{Comment}

DOE should further evaluate the use of other DOE facilities for incineration of MLLW. The State, through the Division of Environmental Quality, has been working with DOE towards a solution for the limited treatment technologies currently available for mixed waste. The ongoing dialogue between regulators and DOE are designed to identify, on a nation-wide basis, available technologies, treatment capacities and waste volumes. The decision to expand WERF to include 
MLLW from on-site and off-site sources should be reassessed considering the discussions on FFCA requirements.

\section{Response}

The use of other DOE facilities for incineration of INEL MLLW was evaluated in Sections 1.3, "Need for Agency Action," and 4.4.5, "Treat MLLW at Another DOE Incinerator and Continue to Incinerate, Compact, and Size LLW at WERF." This evaluation determined that "WERF is the only operable DOE facility capable of incinerating INEL MLLW...". DOE-ID supports the ongoing dialogue with regulators to identify, on a nationwide basis, available technologies, treatment technologies, and waste volumes. However, it is important to resolve the immediate needs to treat MLLW to comply with RCRA requirements for storage and disposal and to provide support for ongoing INEL activities that generate MLLW. Longer-term complex- wide solutions will be considered during agreement negotiations in accordance with the FFCA. In addition, the ER\&WM PEIS and the INEL ER\&WM EIS will consider potential treatment alternatives for all DOE wastes, including LLW and MLLW. The proposed action addressed in this EA does not preclude such future alternatives.

\section{Comment}

The volume of LLW through September 1993 is estimated by DOE at $9,500 \mathrm{~m}^{3}$. Based upon data previously provided, the State estimates the figure to be $5,200 \mathrm{~m}^{3}$. This number is extrapolated from second quarter 1992 data provided by DOE. Requests for updated information have not been answered to date. If State estimates accurately reflect the LLW inventory expected in September 1993, using historic processing efficiencies, LLW inventory should be processed within 21 months. This is well below DOE estimates and contradicts on the bases for the proposal.

\section{Response}

The projected volume of $9,500 \mathrm{~m}^{3}$ of LLW through September 1993 includes LLW that is currently stored at INEL generation facilities. Section 1.3 identifies that "The LLW is presently stored outside WERF on asphalt pads and at generator sites in plywood boxes or cargo containers." The estimate of $9,500 \mathrm{~m}^{3}$ includes the LLW stored at the generator sites.

\section{Comment}

Safety analysis reports (SAR) indicate that metal decontamination and melting are available techniques at WERF. WERF SAR Rev. 7 (Feb. 1987). Again, the "need" for expanded treatment techniques does not justify off-site treatment. 
Response

The WERF SAR, Rev. 7 (Feb. 1987) is being updated to reflect only those technologies that are currently available at WERF. The 1987 SAR includes experimental technologies such as decontamination and melting that were subsequently discontinued.

\section{Section Comments}

\subsection{Operational Impacts}

\section{Comment}

The EA references an isokinetic stack sampling. The sentence implies that the sampling is a real-time monitoring system ("...flow measurements, and continuous, isokinetic stack sampling..."). The description should be corrected to reflect isokinetic monitoring abilities.

\section{Response}

The sentence was reworded to state: "Differential pressure measurements, flow measurements, and continuous stack sampling monitor any degradation of the filtration system. Additionally, an isokinetic stack sampling system monitors actual stack emissions of radioactive material."

\subsubsection{Radiological Impacts}

\section{Comment}

It is unclear whether the radionuclide release rate based upon analysis of previous campaigns' fly ash are representative of the proposed MLLW runs. For example, aqueous solutions and the off-site wastes have not been incinerated at WERF and may have different release rates due to generation processes or constituents. DOE should justify why the release rates for previous campaigns conservatively bound these proposed campaigns.

\section{Response}

The radionuclide distribution in the WERF emissions is based on the best available information from analysis of ash samples and knowledge of INEL waste generating processes (including liquid and aqueous wastes). The EA release rate limits were established such that the total dose rate from all nuclides would not exceed a dose of $0.1 \mathrm{mrem} / \mathrm{yr}$ at the INEL boundary. Actual waste feed rates will be controlled within the bounds established by the EA, air permit, and waste acceptance criteria (WAC). The risk evaluation in the EA is extremely conservative. As described in Section 4.1.1.1, "Radiological Impacts", the risk analysis in the EA is based on processing wastes containing over $1,076 \mathrm{Ci}$ per year. During six previous years of operations, WERF processed only. $17.9 \mathrm{Ci}$. The sources and characteristics of the waste feed have not 
changed significantly. Therefore, DOE considers the EA to contain a robust analysis of potential risks.

\section{Comment}

Worker dose rate was calculated using 100 meters under CAP-88. An explanation of this choice should be presented in the text.

\section{Response}

The following footnote was added to the page 29. "The minimum distance of $100 \mathrm{~m}$ is frequently used in environmental impact analysis because Gaussian dispersion equations used in most dispersion codes are not intended for nearby dispersion calculations." $100 \mathrm{~m}$ is felt to be the minimum distance for which reasonable dispersion estimates can be obtained.

\section{Comment}

In Table 3, the row labeled "Cancer Risk" under Population is misleading. A more appropriate description would be "Excess Cancer Deaths in Exposed Population."

\section{Response}

Footnote was added to Table 3. "c. Estimated additional number of fatal cancers per year in the affected population of 160,120 persons (1990 census data). The risk to an individual (increased cancer risk per person) is the stated risk (total cancers) divided by the population size. For example, the "annual total" risk (from compaction and sizing releases) of an individual developing fatal cancer equals 1.8E-09 (2.9E-04 / 160,120), or about 1 in 552,000,000.

\section{Comment}

On page 29, the reference to $1,076 \mathrm{Ci}$ for Table 2 release rates is incorrect. The correct number is $3,587 \mathrm{Ci}$.

\section{Response}

The nominal baghouse/HEPA filter efficiency cited was in error, it should be $99.9 \%$; therefore, the $1,076 \mathrm{Ci}$ is the correct number.

\subsubsection{Nonradiological Impacts}

\section{Comment}

The EA does not discuss the concentration of metals in the feed stock. This would set the feed rates and affect the exposure. More discussion is warranted. 


\section{Response}

Metal objects are separated from incinerable waste at the points of generation. Packages are certified to meet WERF WAC by the generators, and WERF personnel inspect waste data. forms, shipping records and manifests, characterization reports and certification statements prior to waste acceptance. In addition, each waste container is inspected by radiography before entering the incinerator. Wastes containing metal constituents would be fed into the incinerator at controlled rates established to remain within limits of the air permit and the administrative rate in the EA Table 6.

\section{Comment}

For non-radiological dispersion modeling, DOE uses RSAC-4 computer code. DOE must discuss why a radiological dispersion code is being used for chemicals in light of the Department's decision to use ISC2ST in the INEL ER\&WM EIS.

\section{Response}

The RSAC-4 code was used in order to bound expected short-term consequences of WERF releases. Being an accident code designed for modeling short-term releases, RSAC-4 computes the highest expected downwind concentrations based on user-defined meteorological conditions (usually stability category $F$, and $0.5 \mathrm{~m} / \mathrm{s} \& 2 \mathrm{~m} / \mathrm{s}$ wind speeds for distances less than and greater than $2 \mathrm{~km}$, respectively). RSAC-4 gives higher concentrations than would result from using ISC2ST, which uses average, site-specific meteorology.

Furthermore, the ISC2ST code is more complex than was considered necessary for the WERF application. In Section 1 of EPA's User's Guide for ISC2ST, the EPA recommends that "Simpler and less expensive computerized models...should be used for applications that do not require at least one of the ISC2ST Model features." For example, the ISC2ST code is especially useful for modeling releases from multiple emission points in a "complex"; this feature was not needed in the case of WERF.

\subsection{Potential Impacts from Accidents}

\section{Comment}

Tables 11, 12, and 13 reference an American Conference of Governmental Industrial Hygienists (ACGIH) documents that contains Operational Safety and Health Act (OSHA) permissible exposure limits (PEL). The referenced document does not contain the OSHA values. Using ACGIH is acceptable. However, the values are not OSHA values.

\section{Response}

The indicated OSHA PELs are included in the ACGIH, 1991 reference. However, for clarity the table footnotes/references have been changed to 29 CFR 1910.1000 . 


\title{
Response to the Shoshone-Bannock Tribes Comments
}

\author{
Section 2.2 Proposed Commercial LLW Treatment
}

\section{Comment}

The proposed action includes using licensed and permitted commercial LLW treatment facilities for supplemental LLW volume reduction. It is anticipated that a portion of the accumulated inventory and a portion of the newly generated LLW would be processed at commercial facilities. The actual distribution of waste between WERF and commercial processing facilities has not been determined. A list of potential vendors and a complete outline of transportation control criteria should be reviewed by our department, as geographic location of prospective vendor may immediately affect the Tribe during transferral or emissions from routine plant operations. This request ensures that the Tribe has the opportunity to protect the health, welfare, and safety of its members, natural resources, and the environmental and cultural resources.

\section{Response}

Transportation of the LLW for offsite commercial processing would be performed in accordance with applicable Department of Transportation and Nuclear Regulatory Commission (NRC) regulations. DOE-ID will provide additional requested information on waste processing geographic locations and transportation plans as it becomes available. Section 4.2 of the EA,"Impacts of Transportation of LLW to and from INEL," evaluates impacts associated with the transportation of LLW using a conservative or "bounding" scenario. The last paragraph of Section 4.2 discusses the potential impacts of transporting essentially all of the LLW and MLLW across the Fort Hall Indian Reservation.

All of the known prospective commercial waste processing facilities are outside of Idaho. The offsite LLW treatment facilities would be licensed and permitted by the host state and/or NRC. The facility's emissions and operations would be documented as required by their respective state and federal licenses, permits, and environmental analysis as applicable.

\section{Section 4.1 Operation Impacts of Proposed Action}

\section{Comment}

Primary impacts from WERF operations from airborne emissions of radionuclides (from incinerating, stabilizing, compacting, and sizing), hazardous materials, and criteria pollutants, upon initial startup, should be made available to natural resources trustees. This would confirm the EPA's National Emission Standards Hazardous Air Pollutants (NESHAP) (40 CFR 61 Subpart I) are met. Information during the trial burn and emission monitoring programs concerning nonradiological releases should also be available for review. 
Finally, since WERF operations were suspended in February 1991, accumulating inventory of LLW, which prompted the INEL to review waste management alternatives as stated in Section 1.3, "Need for Agency Action," is justified. It is my opinion that the proposed DOE action, rather than the alternatives to the proposed action, will provide the preferred method of determining whether DOE should prepare an EIS or to issue a "FONSI".

\section{Response}

DOE-ID will provide the requested WERF startup data on airborne emissions as information becomes available. The emission data will include National Emission Standards for Hazardous Air Pollutants (NESHAP) reports on radionuclide emissions, trial burn results, and startup monitoring summaries on hazardous materials and criteria pollutants. In addition, annual INEL environmental monitoring reports will continue to be provided to Fort Hall's INEL information repository.

Thank you for your comments on the environmental assessment and the proposed action. DOE will use the environmental assessment of the proposed action as a basis for determining whether to issue a "Finding of No Significant Impact" or to prepare an Environmental Impact Statement. Your comments will assist DOE's decision-making process. 